\title{
Summary of Four Release Consequence Analyses for Hypothetical Nuclear Waste Repositories in Salt and Granite
}

\author{
C. R. Cole \\ F. W. Bond
}

December 1980

Prepared for the U.S. Department of Energy under Contract DE-AC06-76RLO 1830

Pacific Northwest Laboratory Operated for the U.S. Department of Energy by Battelle Memorial Institute 


\title{
NOTICE
}

This report was prepared as an account of work sponsored by the United States Government. Neither the United States nor the Department of Energy, nor any of their employees, nor any of their contractors, subcontractors, or their employees, makes any warranty, express or implied, or assumes any legal liability or responsibility for the accuracy, completeness or usefulness of any information, apparatus, product or process disclosed, or represents that its use would not infringe privately owned rights.

The views. opinions and conclusions contained in this report are those of the contractor and do not necessarily represent those of the United States Government or the United States Department of Energy.

\section{PACIFIC NORTHWEST LABORATORY \\ operated by \\ BATTELLE \\ for the \\ UNITED STATES DEPARTMENT OF ENERGY \\ Under Contract DE-AC06-76RLO 1830}

\author{
Printed in the United States of America \\ Available from \\ National Technical Information Service \\ United States Department of Commerce \\ 5285 Port Royal Road \\ Springfield, Virginia 22151
}

Price: Printed Copy $\$$

$\because$ Microfiche $\$ 3.00$

NTIS

- Pages Selling Price

$\begin{array}{lr}001-025 & \$ 4.00 \\ 026-050 & \$ 4.50 \\ 051-075 & \$ 5.25 \\ 076-100 & \$ 6.00 \\ 101-125 & \$ 6.50 \\ 126-150 & \$ 7.25 \\ 151-175 & \$ 8.00 \\ 176-200 & \$ 9.00 \\ 201-225 & \$ 9.25 \\ 226-250 & \$ 9.50 \\ 251-275 & \$ 10.75 \\ 276-300 & \$ 11.00\end{array}$


33679000561904

\author{
SUMMARY OF FOUR RELEASE \\ CONSEQUENCE ANALYSES FOR \\ HYPOTHETICAL NUCLEAR WASTE \\ REPOSITORIES IN SALT AND \\ GRANITE
}

C. R. Cole

F. W. Bond

December 1980

Prepared for the U.S. Department of Energy under Contract DE-AC06-76RLO 1830

Pacific Northwest Laboratory

Richland, Washington 99352 


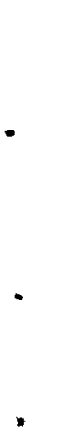


Release consequence methodology developed under the Assessment of Effectiveness of Geologic Isolation Systems (AEGIS) program has now been applied to four hypothetical repository sites. This paper summarizes the results of these four studies in order to demonstrate that the far-field methodology developed under the AEGIS program offers a practical approach to the post-closure safety assessment of nuclear waste repositories sited in deep continental geologic formations.

Because of the generic and hypothetical nature of the various studies reported, along with the different levels of complexity of the models used, one should not attempt to use the information to judge the merits of one site or medium as against another. Instead it can be used to draw some general conclusions regarding release consequence methodology and other important areas related to nuclear waste repositories elucidated by these studies.

The four studies are briefly described and compared according to the following general categories:

- physical description of the repository (size, inventory, emplacement depth)

- geologic and hydrologic description of the site and the conceptual hydrologic model for the site

- description of release scenario

- hydrologic model implementation and results

- engineered barriers and leach rate modeling

- transport model implementation and results

- dose model implementation and results.

These studies indicate the following:

- Numerical modeling is a practical approach to post-closure safety assessment analysis for nuclear waste repositories.

- Near-field modeling capability needs improvement to permit assessment of the consequences of human intrusion and pumping well scenarios. 
- Engineered barrier systems can be useful in mitigating consequences for postulated release scenarios that short-circuit the geohydrologic system.

- Geohydrologic systems separating a repository from the natural biosphere discharge sites act to mitigate the consequences of postulated breaches in containment.

- Engineered barriers of types other than the containment or absorptive type may be useful. 
SUMMARY

INTRODUCTION

GENERAL DESCRIPTION OF A REPOSITORY.

DETAILED DESCRIPTION OF THE INFCE GRANITE REPOSITORY. • • • • • 6

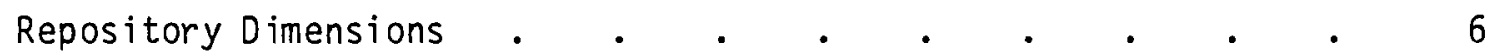

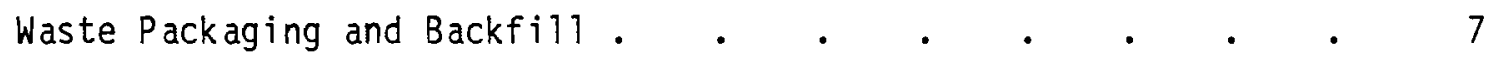

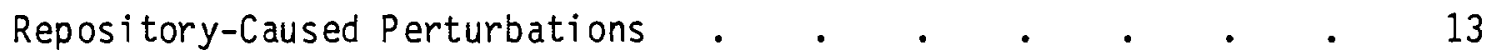

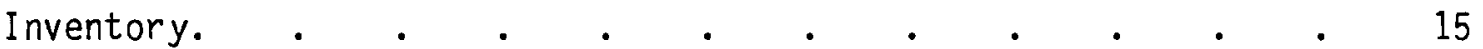

INFCE SALT REPOSITORY •

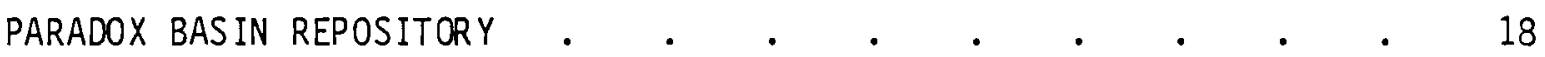

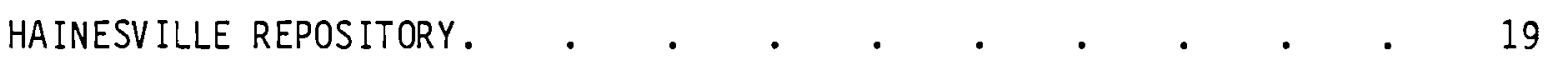

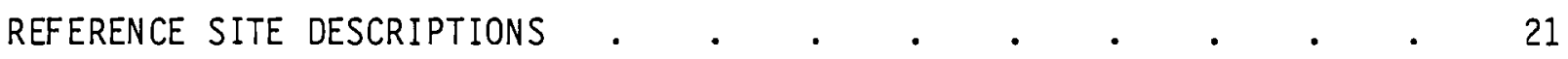

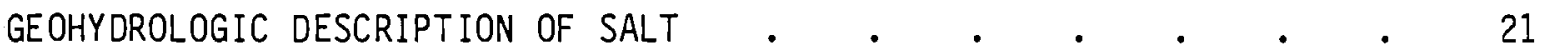

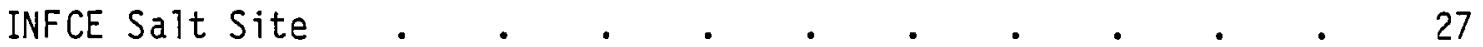

Paradox Basin Site. $. \quad . \quad . \quad . \quad . \quad . \quad . \quad . \quad . \quad 29$

Hainesville Site . . . . . . . . . . . . . . 33

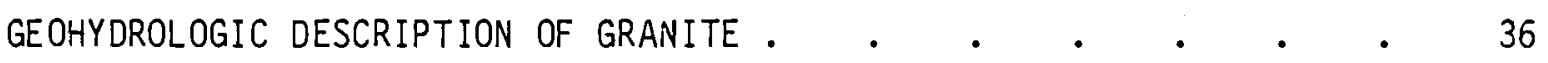

INFCE Granite Site . . . . . . . . . . . 40

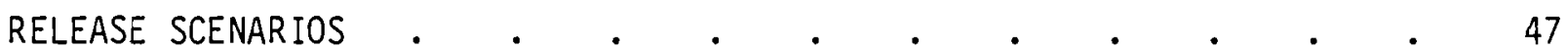

INFCE SALT SCENARIO

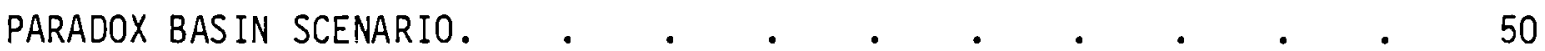

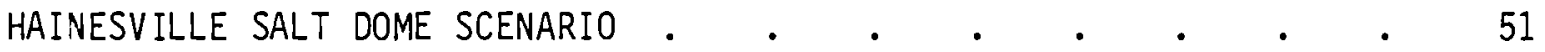

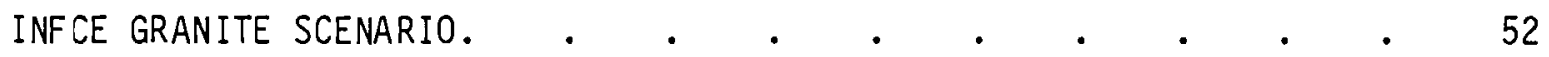

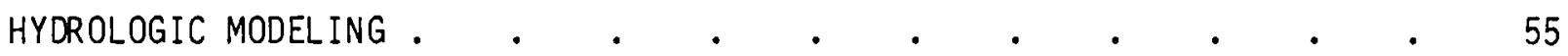

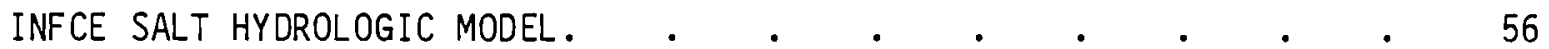

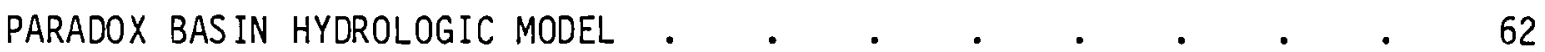

HAINESVILLE HYDROLOGIC MODEL $\quad \cdot \quad \cdot \quad \cdot \quad \cdot \quad \cdot \quad \cdot \quad \cdot \quad \cdot \quad \cdot \quad 65$

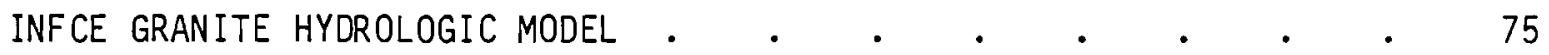

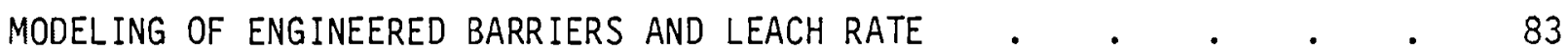

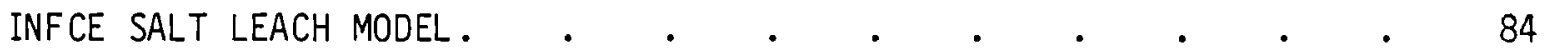

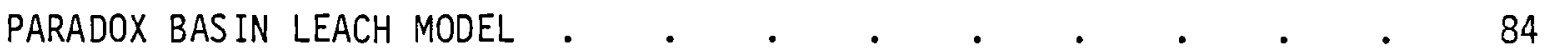




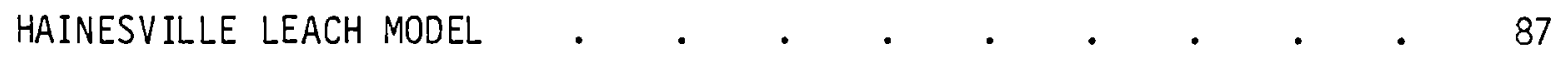

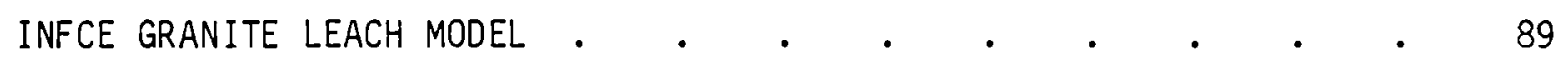

TRANSPORT MODELING

INFCE SALT TRANSPORT MODEL •

PARADOX BASIN TRANSPORT MODEL

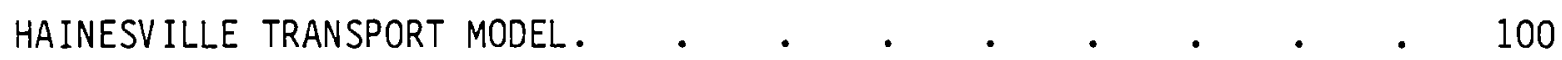

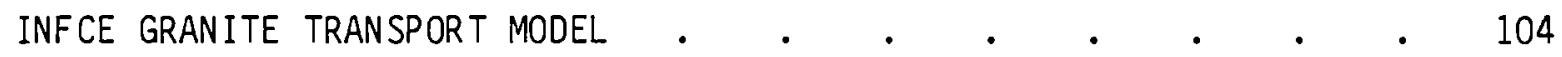

DOSE MODELING •

INFCE SALT DOSE MODEL . $. \quad . \quad . \quad . \quad . \quad . \quad . \quad . \quad . \quad 109$

PARADOX BASIN STUDY . . . . . . . . . . . . . . 110

HAINESVILLE DOSE MODEL. $. \quad . \quad . \quad . \quad . \quad . \quad . \quad . \quad$. 111

INFCE GRANITE DOSE MODEL

CONCLUS IONS

ACKNOWLEDGMENTS.

REEERENCES. . . . . . . . . . . . . 123 


\section{FIGURES}

1 Schematic Diagram of Release Consequence Analysis. . . . . 3

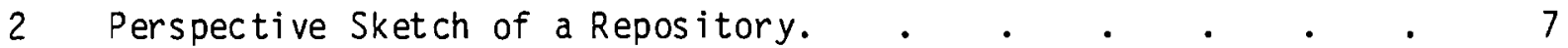

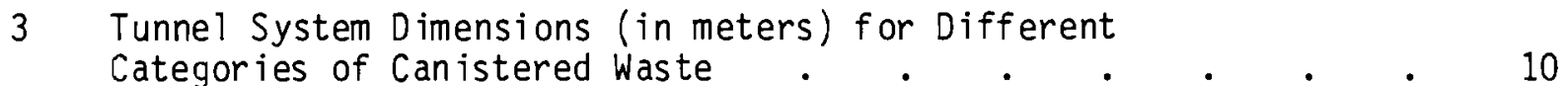

4 Section Through Disposal Tunnel for Spent Fuel (LWR) Canisters After Sealing. . . . . . . . . . . 11

5 Section Through Disposal Tunnel for Spent HWR Fuel After Sealing. . . . . . . . . . . . . 12

6 Section Through Disposal Tunnel for Vitrified HLW Canisters After Sealing . . . . . . . . . . . 14

7 Section Through Disposal Tunnel for Drums with

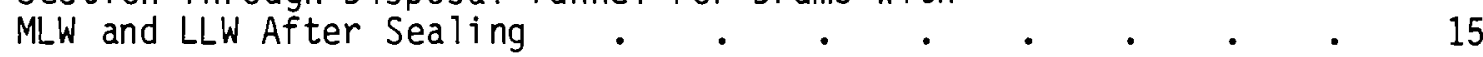

8 Temperature at the Canister Surface and in the Bedrock

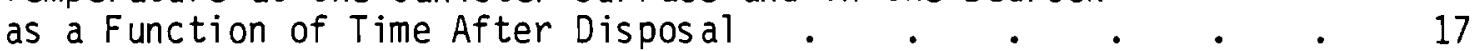

9 Temperature at the Canister Surface and in the Bedrock

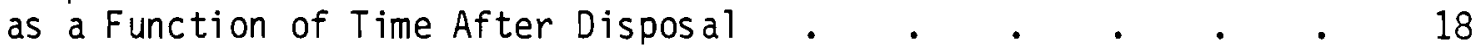

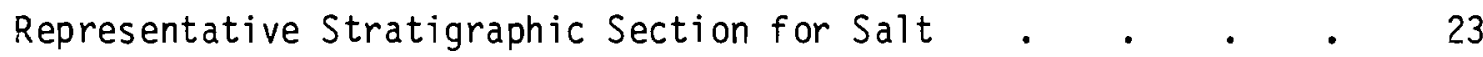

11. Generalized Geologic Column of the Paradox Bedded Salt Region . . . . . . . . . . . . . 24 Hainesville Salt Dome Site North-South Cross Section

13 Cross-Section View of Regional Discharge to a River (vertical scale exaggerated). $\quad . \quad$ e $\quad . \quad . \quad . \quad . \quad 28$ Paradox Basin Bedded Salt Region . Base Map of the Paradox Model Region . . . . . . . 31

17 Ranges in Permeability for Crystalline Rock as a

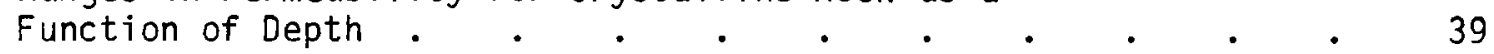

18 Variation in Three Types of Porosity . . . . . . . . 40

19 Reference Repository Site in Granite, Illustrating Boundaries, Fractures and Water Table . . . . . . . 43 Schematic of Fractured Rock Mass . . . . . . . . . 45 Plan View of INFCE Salt Study Model Region Cross Section of the Five Geologic Layers Used to Define INFCE Salt Study Model Region.

23 Three-Dimensional View of INFCE Salt Model Region 
24 Contour Plot of Mode 1-Predicted Vertical GroundWater Potentials with Superimposed Streamlines

(INFCE Salt Study)

Potentiometric Map of Paradox Basin Model Area

Section Perpendicular to Hydraulic Gradient in

Paradox Basin.

27 Section Parallel to Hydraulic Gradient in Paradox Basin

Modeled Region with Boundary Conditions and Composition Potentials for the Paradox Basin.

29 Ground-Water Flow Tubes and Streamlines from Breached Repository to the Colorado River for the Paradox Basin Study. . . . .

30 Schematic Representation of Hainesville Salt Dome Hydrogeology Before Eventual Collapse of the Abandoned Solution Mine . $. \quad . \quad . \quad . \quad . \quad$.

31 Finite Element Grid with Closer Node Spacing near Hainesville Dome Breach . . . . . . . .

32 Three-Dimensional Stratifications of the Region

Adjoining the Hainesville Salt Dome Used for

Simulation of Flow Through Dome Breach . . . . . . . 70

33a Schematic Representation of Collapsed Hainesville Salt Dome.

33b Uniform Finite Element Grid for Simulation of Flow After Hainesville Salt Dome Collapse . . . . . .

34 Geometry and Boundary Conditions for the WilcoxCarrizo Aquifer (Hainesville Study)

35 Modeled Ground-Water Aquifer Showing Potential Contours and Flow Tubes from the Hainesville Dome, Case 1

Modeled Aquifer Showing Potential Contours and Flow Tubes from the Hainesville Dome, Case 2.

37 Finite Element Grid Representation of INFCE

Granite Model Region

$38 X-Y$ Paths for Streamlines Starting at the Upper Left and Right Corners of the INFCE Granite Repository as Well as the Middle

39 Release Rate Curve for Reactor Strategies 1 and 4 of the INFCE Salt Study and for the Paradox Basin Study 
41 Fraction of Waste Exposed Needed To Reach Solubility Limits for Specific Flow Rates and Leach

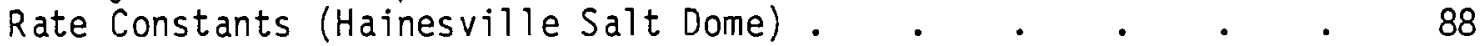

42 Solution Mining Scenario for Spent Fuel Repository 70-yr Individual Dose from 50-yr Ingestion Doses in rem (Hainesville Study).

\section{TABLES}

1 Sumary of Packaged Waste Arisings from Reference

Fue 1 Cycles/GWe yr.

Repository Data, 100 GWe-yr Generated Power, 10-Yr-

0ld HLW

3 Waste Package Descriptions

4 Typical Values and Ranges in Hydrologic Properties

and Parameters of the Sites . . . . . . . . . . 26

5 Hydrogeologic Parameters for Generic Salt

Stratigraphy

Geologic Formations in the Paradox Modeled Area

28 Degrees of Permeability of Various Rock Types

8 Hydraulic Properties of Different Hydrogeologic Structures for the Reference Repository Site Area in Granite

9 INFCE Salt Study Finite Element Model Hydrogeologic Input $P$ arameters

10 Paradox Basin Hydrologic Model Results . . . . . .

11 Hydraulic Properties of Different Hydrogeologic Structures in the Reference Repository Site Area in Granite

12 Sumary of the Equivalent One-Dimensional Columr Data Required of a One-Dimensional Simulation of Contaminant Transport

13 Parameters Used by the Leach Model to Generate the Leach Rate Functions Shown in Figures 39 and 40

14 INFCE Salt Study Transport Model Input Parameters for all Seven Reactor Strategies Modeled

15 Sumary of the INFCE Transport Model Results of the Seven Reactor Strategies.

16 Radionuclides Modeled by the Transport Code in the Paradox Basin Study. 
17 Simulation Inventories, Half-Lives, and $K_{d}$ Values

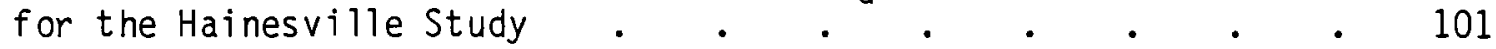

18 Hainesville Study Transport Parameters . . . . . . . 102

19 Cumulative Radiocontaminant $D$ ischarge in Curies for the Four Hainesville Study Release Scenarios After Geotransport Based on Solution Mining Beginning at Time 100 Years After Closure ..$\quad$. . . . . 103

20 Radioactivity ( $\mathrm{C} i$ ) in Spent Fuel Waste or Vitrification Reprocessing Waste for INFCE Granite Study

Reference Fuel Cycles Per GWe yr (After 10 Years). . . . 105

21 Distribution Coefficients, $K_{d}$, and Retention Factors, $K_{j}$, Used in INFCE Granite Study Transport Calculations . . 106

22 INFCE Granite Study Maximum Radionuclide Discharge Rates $(\mathrm{Ci} / \mathrm{yr})$ and Times for the Maximum (Year) for High-Level Waste and Spent Fuel . . • . . . . 107

23 Radiation Doses Calculated for Hainesville Solution Mining Scenario (50-yr Ingestion) .

24 Annual Maximum Individual Doses (rem/yr) for High-Level Waste and Spent Fuel . $\quad$. . . . . . 116

25 Annual Maximum Individual Doses (rem/yr)

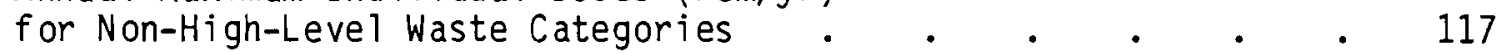


INTRODUCTION

The National Waste Terminal Storage (NWTS) Program is concerned with developing methods for using geologic formations to safely dispose of spent fuel and/or high-level radioactive waste from commercial nuclear power reactors. Part of this program is managed for the Department of Energy by Battelle Memorial Institute's Office of Nuclear Waste Isolation (ONWI). Under ONWI sponsorship, the Pacific Northwest Laboratory is responsible for the Assessment of Effectiveness of Geologic Isolation Systems (AEGIS) Program, formerly the Waste Isolation Safety Assessment Program (WISAP).

The AEGIS mission is to develop and implement methods to assess the postclosure safety of geologic repositories, methods that are eventually to be applied in site selection, qualifications, and licensing. Compared with safety assessments for other engineered systems, however, the assessment of geologic isolation safety is unique because of the uncertainties resulting from

- the long time periods involved in the assessments

- the hypothetical nature and low probabilities of the nuclide release scenarios and

- the limited ability to characterize deep geohydrologic systems.

The AEGIS methodology for release consequence analysis has now been applied to two generic sites, salt ${ }^{(1)}$ and hard rock (granite), (2) for the International Nuclear Fuel Cycle Evaluation (INFCE) Program. In addition, this methodology has been applied to two specific hypothetical sites in the U.S. where a moderate amount of actual data for the geohydrologic system exists. One site is in bedded salt in the arid West, ${ }^{(3)}$ and the other is a salt dome near the Gulf Coast. (4) The AEGIS methodology has al so been compared to the release consequence methodology used for the Waste Isolation Pilot Plant Environmental Impact Statement/Environmental Report (WIPP EIS/ER). $(5,6)$ Other release consequence studies, al ready performed for generic sites by England, $(7)$ Sweden, $(8,9)$ Finland, $(10)$ and Belgium $(11)$ can provide additional usefur material. 
The purpose of this paper is to sumarize four studies ${ }^{(1-4)}$ to illustrate the use and applicability of the AEGIS release consequence analysis methodology. The reader is cautioned, however, not to use this synopsis to compare one medium with another since the amount and quality of the data vary from one site to another. This is especially true for the INFCE studies, where dose models of different levels of sophistication were used. Methodology for generating release scenarios will not be treated here although the release scenario used for each study will be discussed.

In the two INFCE studies, release consequence impacts were analyzed for wastes from seven reference fuel cycles or reactor strategies provided by Working Group 7 of the INFCE Committee. These fuel cycles are as follows:

1. light water reactor (LWR) with spent fuel disposal

2. LWR with plutonium recycle

3. fast breeder reactor (FBR) with plutonium recycle

4. heavy water reactor (HWR) with spent fuel disposal

5. HWR with plutonium recycle

6. HWR with uranium-thorium recycle

7. high-temperature reactor (HTR) with uranium-thorium recycle.

The Paradox and Hainesville studies were conducted essentially only for Fuel Cycle 1, with the inventory adjusted for projected U.S. power production.

The AEGIS methodology for release consequence analysis has thus far concentrated on far-field modeling technologies (regional hydrologic transport and dose codes). Near-field effects were handled by conservative assumptions or simple leach rate or engineered barrier models. Release scenario methodology is being developed under AEGIS, but it was not used in the cases presented here. Release scenarios were developed via modified Delphi methods utilizing expert opinion. Figure 1, a general diagram of the interrelationships between the various $f$ acets of release consequence analysis, shows the path from the data on the site through the modeling required to estimate possible future doses to man resulting from a potential release.

As this document sumarizes four separate reports, it uses the same system of units found in each of the original reports. 


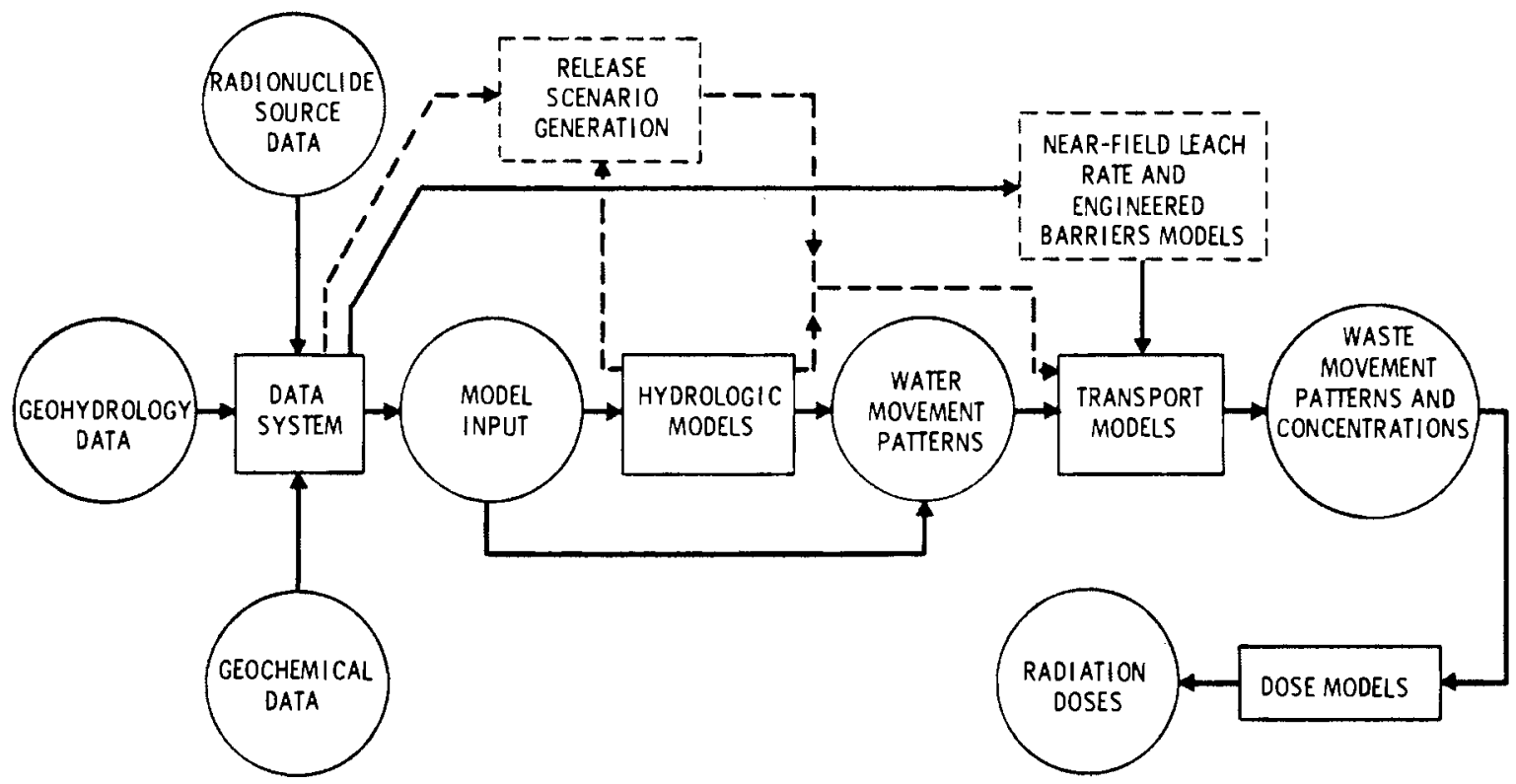

FIGURE 1. Schematic Diagram of Release Consequence Analysis 
, 


\section{GENERAL DESCRIPTION OF A REPOSITORY}

The following brief discussion provides a physical and functional description of a nuclear waste repository in deep geologic medium. A nuclear waste repository in deep geologic medium consists of the following:

- surface facilities for receiving and preparing waste for burial

- a system of shafts to give access to a deep, stable, low-permeability geologic medium that will provide for the primary long-term isolation

- a system of tunnels or storage rooms in the deep geologic medium in which the waste canisters containing the waste form are so emplaced as to minimize perturbations on the geology as a result of the heating and radiation caused by the waste.

A nuclear waste repository is a multiple-barrier containment system with the following barriers:

- stable, deep, low-permeability geologic medium containing the repository, which has been appropriately sealed following emplacement of the wastes

- the geohydrologic system separating the deep geologic medium from the biosphere, which acts to retard, disperse and dilute any wastes that $m$ ight escape a breached repository

- engineered backfill for the tunnels, shafts and waste emplacement holes within the repository, designed with the appropriate chemical and/or physical properties to minimize the consequences of a breached repository

- engineered waste canisters designed to allow for safe handling of the waste during emplacement and for some time period on the order of 1000 years or greater while the potentially more hazardous fission products are abundant

- the waste form itself, which should have the appropriate chemical and physical properties to minimize leachability should it contact circulating ground waters. 
The generic design for the INFCE hard rock repository will be used to illustrate repository design. Repository designs for the other sites and media are similar in general design and functional parts.

\section{DETAILED DESCRIPTION OF THE INFCE GRANITE REPOSITORY}

The repository facilities comprise surface facilities for receiving and encapsulating the waste plus a tunnel system in the hard crystalline rock (granite) $500 \mathrm{~m}$ below the surface for final disposal (Figure 2). In this concept all categories of waste are disposed of in the same repository even though safety considerations do not require that drums containing medium-level waste (MLW) and low-level waste (LLW) be placed in the same type of repository as high-level waste (HLW, i.e., spent fuel or vitrified waste). Because geochemical conditions are important to the proper functioning of the repository, the various types of wastes are placed in separate parts of the repository, and due regard is given to direction of ground-water flow to avoid negative effects on the geochemical environment.

A11 repository facilities and their operational sequences are designed to protect the public and the operating personnel from radiation and contamination hazards, both during normal operations and emergency or accident situations. Facilities containing radioactive materials are designed to maintain their integrity during natural disasters.

\section{Repository Dimensions}

For both INFCE studies the repository dimensions are based on the repository's ability to hold the waste from 1 year of a 100-GWe economy. Table 1 shows the number of canisters (HLW) and drums (MLW and LLW) from 1 GWe-yr for each of the seven INFCE fuel cycles considered. Table 2 gives repository tunnel lengths, spacings, area and mining requirements for each of the seven fuel cycles, and Figure 3 gives dimensions and spacings for the HLW. Based on the maximum area (122 hectares, range 65 to 122 ) requirement for any of the fuel cycles, the reference repository is assumed to be $1150 \times 1150 \mathrm{~m}$ and $500 \mathrm{~m}$ below the surface. 


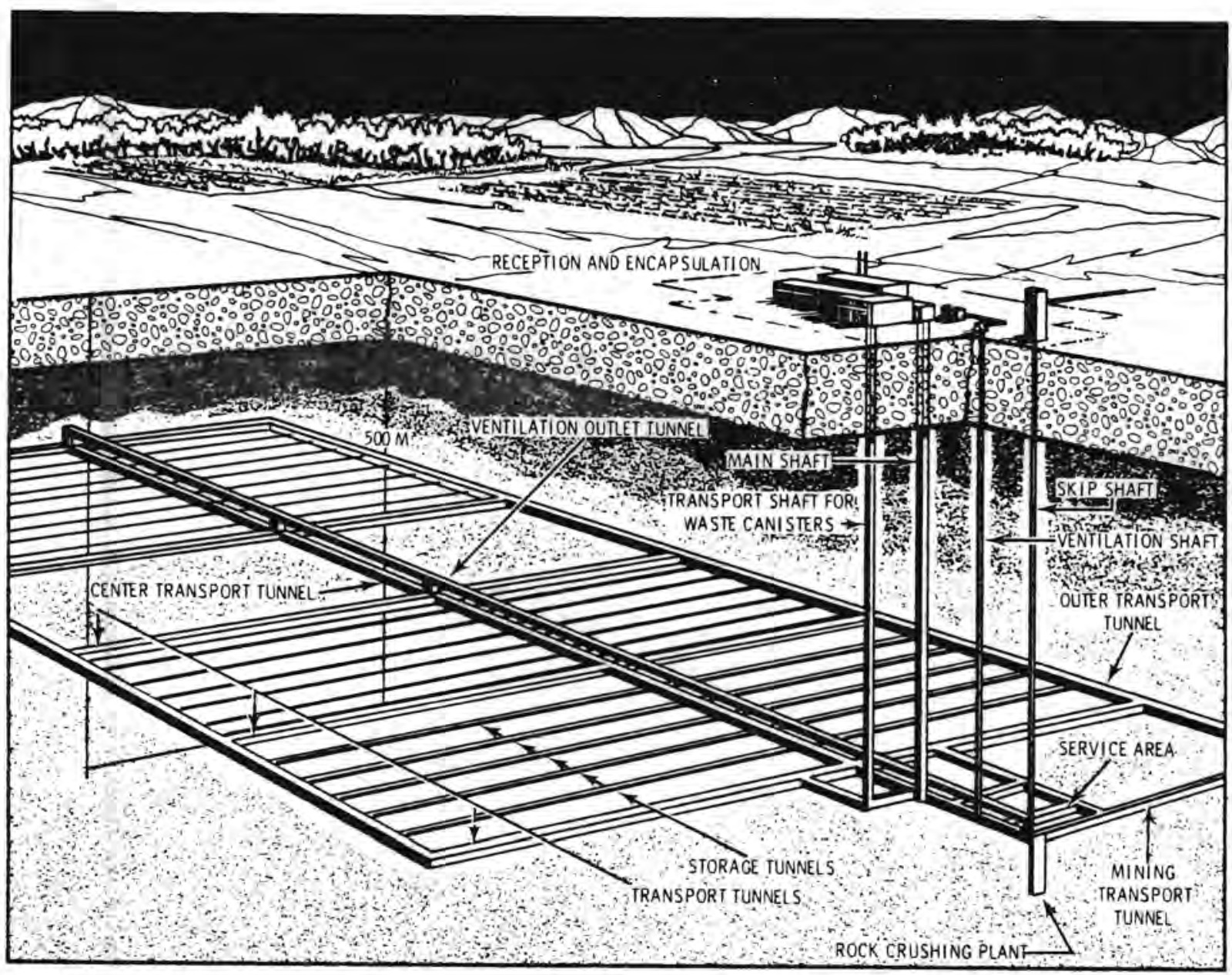

FIGURE 2. Perspective Sketch of a Repository

Waste Packaging and Backfi11

High-level wastes in the form of spent fuel and vitrified waste are encapsulated and emplaced in slightly different ways because of their differing forms and sizes. Canisters with spent fuel are filled with lead and positioned in the repository. The areas around the cans and the tunnel are then backfilled with pure bentonite and bentonite sand mix (containing 80 to $90 \%$ quartz sand), respectively, as shown in Figures 4 and 5. Canisters of vitrified high-level waste are placed in the repository, which is backfilled as 
TABLE 1. Sumary of Packaged Waste Arisings from Reference Fuel Cycles/Give yr

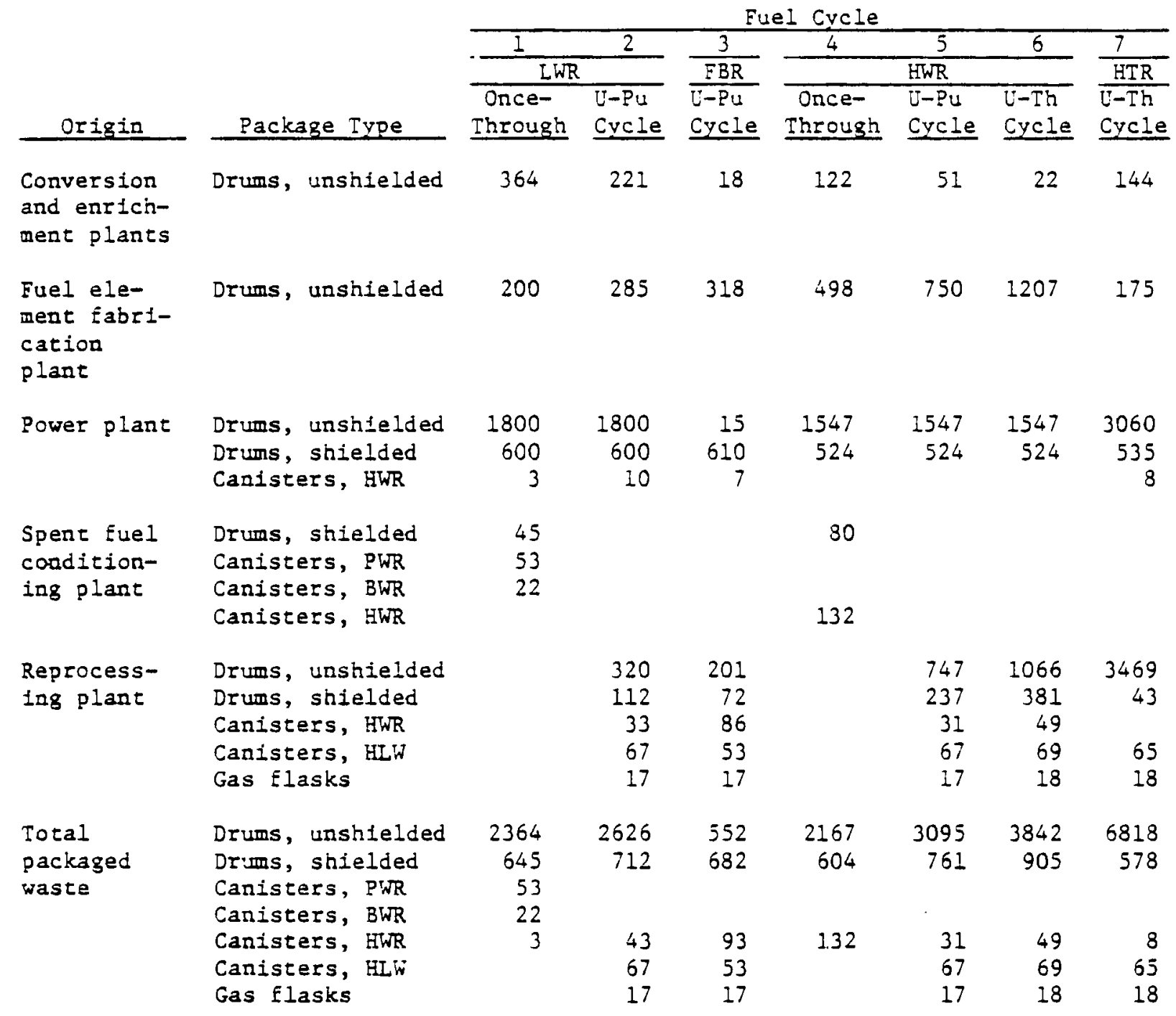


TABLE 2. Repository Data, 100 GWe-yr Generated

Power, 10-Yr-01d HLW

\begin{tabular}{|c|c|c|c|c|c|}
\hline $\begin{array}{l}\text { Fuel } \\
\text { Cycle }\end{array}$ & Trpe of Wasce & $\begin{array}{l}\text { Required } \\
\text { Annual } \\
\text { Lengeh of } \\
\text { Disposal } \\
\text { Tunnels } \\
\text { EL, tI } \\
\end{array}$ & $\begin{array}{l}\text { Distance } \\
\text { Berween } \\
\text { Tunnel } \\
\text { Centers } \\
\quad c, n \\
\end{array}$ & $\begin{array}{c}\text { Required } \\
\text { Annual } \\
\text { Disposal } \\
\text { Area } \\
\text { A, ha } \\
\text { A=c.IL } \\
\end{array}$ & $\begin{array}{l}\text { Annual Volume of } \\
\text { Solid Rock to be } \\
\text { Excavaced, m }{ }^{3} \\
\text { (access cunnels } \\
\text { and sharts excl.) }\end{array}$ \\
\hline 1 & $\begin{array}{l}\text { Canisterad HIN } \\
\text { Other canistered waste } \\
\text { Drummed actinide waste } \\
\text { Drumed nonactinide waste }\end{array}$ & $\begin{array}{r}26,300 \\
210 \\
0 \\
6,020\end{array}$ & $\begin{array}{l}25 \\
15 \\
35 \\
35\end{array}$ & $\begin{array}{l}66 \\
0.3 \\
0 \\
21\end{array}$ & $\begin{array}{r}447,000 \\
3,300 \\
0 \\
440,000\end{array}$ \\
\hline 2 & $\begin{array}{l}\text { Canistered GLN } \\
\text { Other canistered waste } \\
\text { Drumed actinide waste } \\
\text { Drumed nonactinide waste }\end{array}$ & $\begin{array}{r}23,500 \\
3,100 \\
1,180 \\
5,500\end{array}$ & $\begin{array}{l}25 \\
15 \\
35 \\
35\end{array}$ & $\begin{array}{r}59 \\
5 \\
4 \\
19\end{array}$ & $\begin{array}{r}280,000 \\
50,000 \\
87,000 \\
403,000\end{array}$ \\
\hline 3 & $\begin{array}{l}\text { Canistered BLW } \\
\text { Orher canistered waste } \\
\text { Drumed actinide waste } \\
\text { Drumed nonactinide waste }\end{array}$ & $\begin{array}{r}18,600 \\
6,400 \\
1,180 \\
1,290\end{array}$ & $\begin{array}{l}25 \\
15 \\
35 \\
35\end{array}$ & $\begin{array}{r}47 \\
10 \\
4 \\
4\end{array}$ & $\begin{array}{r}220,000 \\
100,000 \\
86,000 \\
94,000\end{array}$ \\
\hline 4 & $\begin{array}{l}\text { Caniscerad GI } \\
\text { Orher canistered wasce } \\
\text { Drumed actinide waste } \\
\text { Drumed nonactinide waste }\end{array}$ & $\begin{array}{r}23,100 \\
210 \\
0 \\
5,540\end{array}$ & $\begin{array}{l}25 \\
15 \\
35 \\
35\end{array}$ & $\begin{array}{c}58 \\
0.3 \\
0 \\
19\end{array}$ & $\begin{array}{r}319,000 \\
3,000 \\
0 \\
406,000\end{array}$ \\
\hline 5 & $\begin{array}{l}\text { Canistered HIN } \\
\text { Orher canistered wasce } \\
\text { Drumed actinide waste } \\
\text { Drumed nonactinide waste }\end{array}$ & $\begin{array}{r}23,450 \\
2,400 \\
3,470 \\
4,240\end{array}$ & $\begin{array}{l}25 \\
15 \\
35 \\
35\end{array}$ & $\begin{array}{r}59 \\
4 \\
12 \\
15\end{array}$ & $\begin{array}{r}279,000 \\
37,000 \\
254,000 \\
311,000\end{array}$ \\
\hline 6 & $\begin{array}{l}\text { Caniscered } \text { 江W } \\
\text { Ocher canistered waste } \\
\text { Drummed actinide waste } \\
\text { Drummed nonactinide waste }\end{array}$ & $\begin{array}{r}24,150 \\
3,650 \\
5,320 \\
4,190\end{array}$ & $\begin{array}{l}25 \\
15 \\
35 \\
35\end{array}$ & $\begin{array}{r}60 \\
5 \\
19 \\
15\end{array}$ & $\begin{array}{r}287,000 \\
57,000 \\
389,000 \\
307,000\end{array}$ \\
\hline 7 & $\begin{array}{l}\text { Caniscered HLW } \\
\text { Ocher canistered waste } \\
\text { Drummed actinide wasce } \\
\text { Drummed nonactinide waste }\end{array}$ & $\begin{array}{r}22,800 \\
550 \\
7,380 \\
7,420\end{array}$ & $\begin{array}{l}25 \\
15 \\
35 \\
35\end{array}$ & $\begin{array}{l}57 \\
0.8 \\
26 \\
26\end{array}$ & $\begin{array}{r}271,000 \\
9,000 \\
540,000 \\
544,000\end{array}$ \\
\hline
\end{tabular}




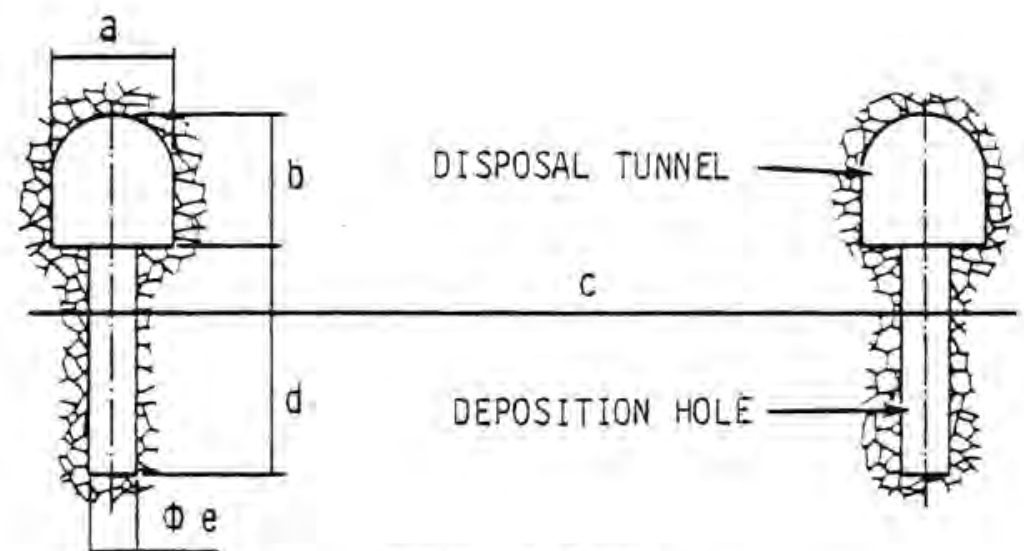

CROSS SECTION

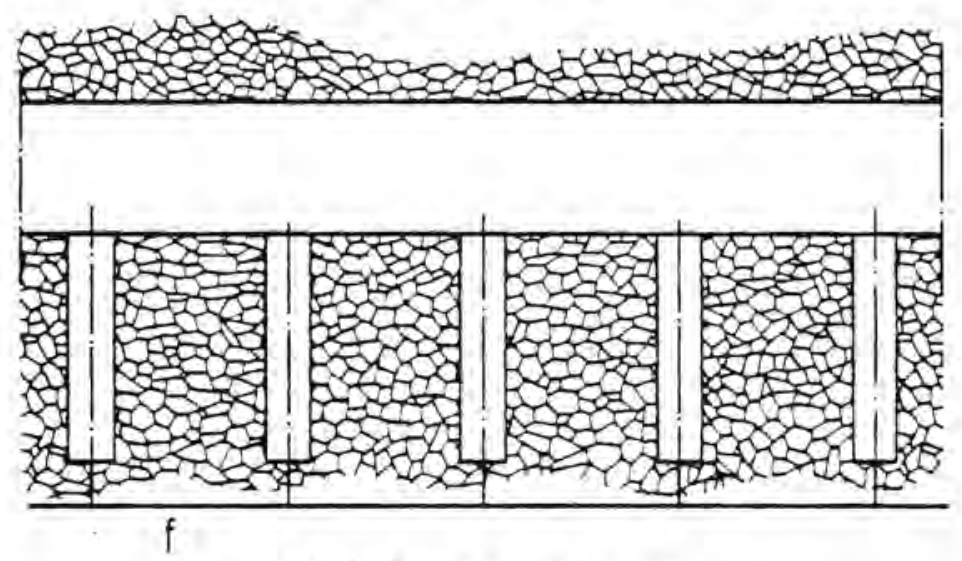

LONGITUDINAL SECTION

\begin{tabular}{|c|c|c|c|c|c|c|c|}
\hline $\begin{array}{c}\text { anister } \\
\text { Type }\end{array}$ & $\begin{array}{l}\text { Waste Type } \\
\text { Contained }\end{array}$ & $\stackrel{a}{\longrightarrow}$ & $\mathrm{b}$ & c & $d$ & e & $\underline{f}$ \\
\hline PWR & Spent PWR Fuel & 3.7 & 4.5 & 25 & 7.9 & 1.0 & 3.5 \\
\hline BWR & Spent BWR Fuel & 3.7 & 4.5 & 25 & 7.9 & 1.1 & 3.5 \\
\hline HWR & Spent HWR Fuel & 3.7 & 3.5 & 25 & 4.5 & 1.5 & 3.5 \\
\hline $\mathrm{HLW}$ & Vitrified HLW & 3.7 & 3.5 & 25 & 5.0 & 0.62 & 3.5 \\
\hline HWR & $\begin{array}{l}\text { Cladding Waste } \\
\text { Control Rods MLW }\end{array}$ & 3.7 & 3.5 & 15 & 8.4 & 1.5 & 3.5 \\
\hline
\end{tabular}

* $\mathrm{n}$ is the number of canisters in each hole.

FIGURE 3. Tunne1 System Dimensions (in meters) for Different Categories of Canistered Waste 


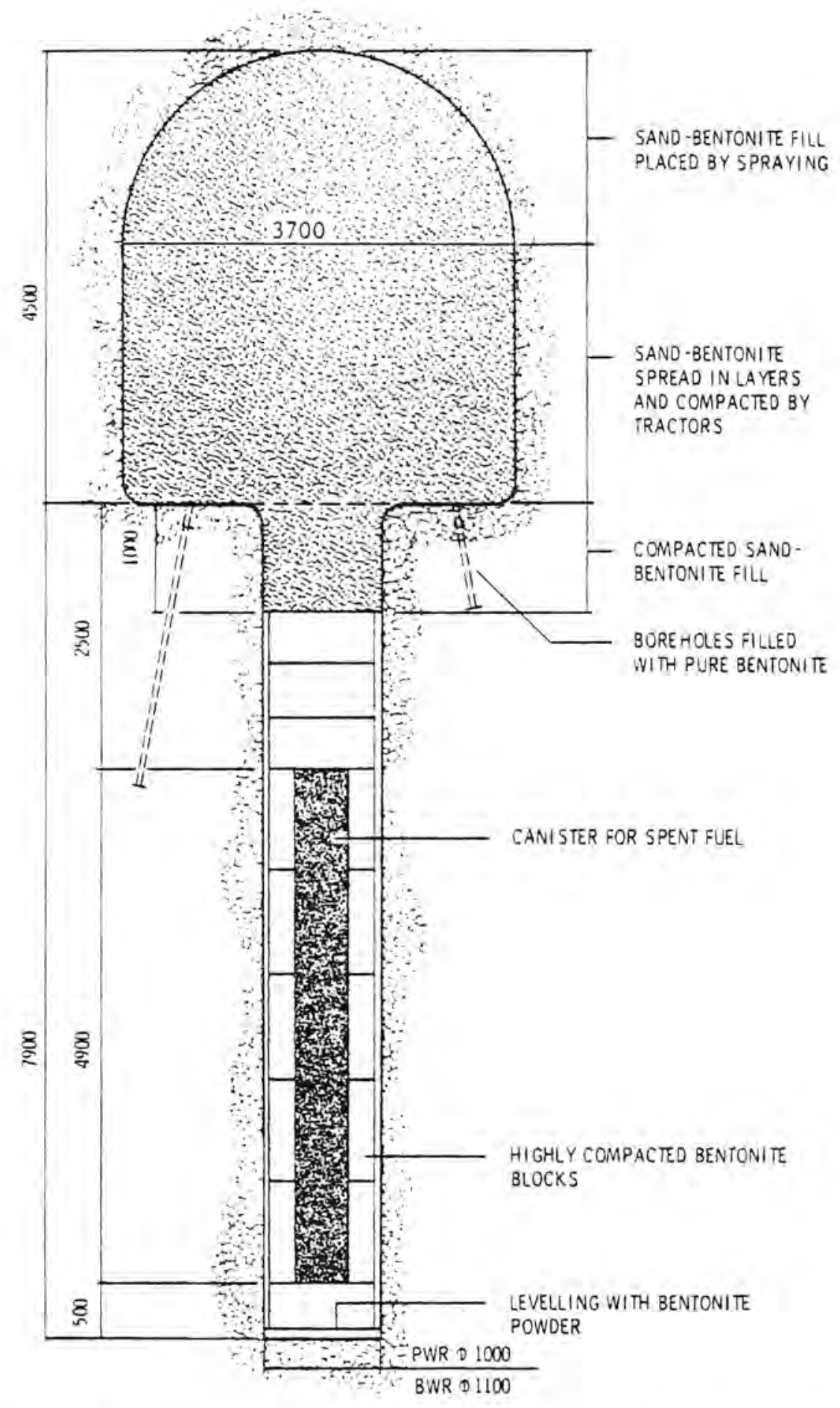

FIGURE 4. Section Through Disposal Tunnel for Spent Fuel (LWR) Canisters after Sealing. Dimensions in $\mathrm{mm}$. 


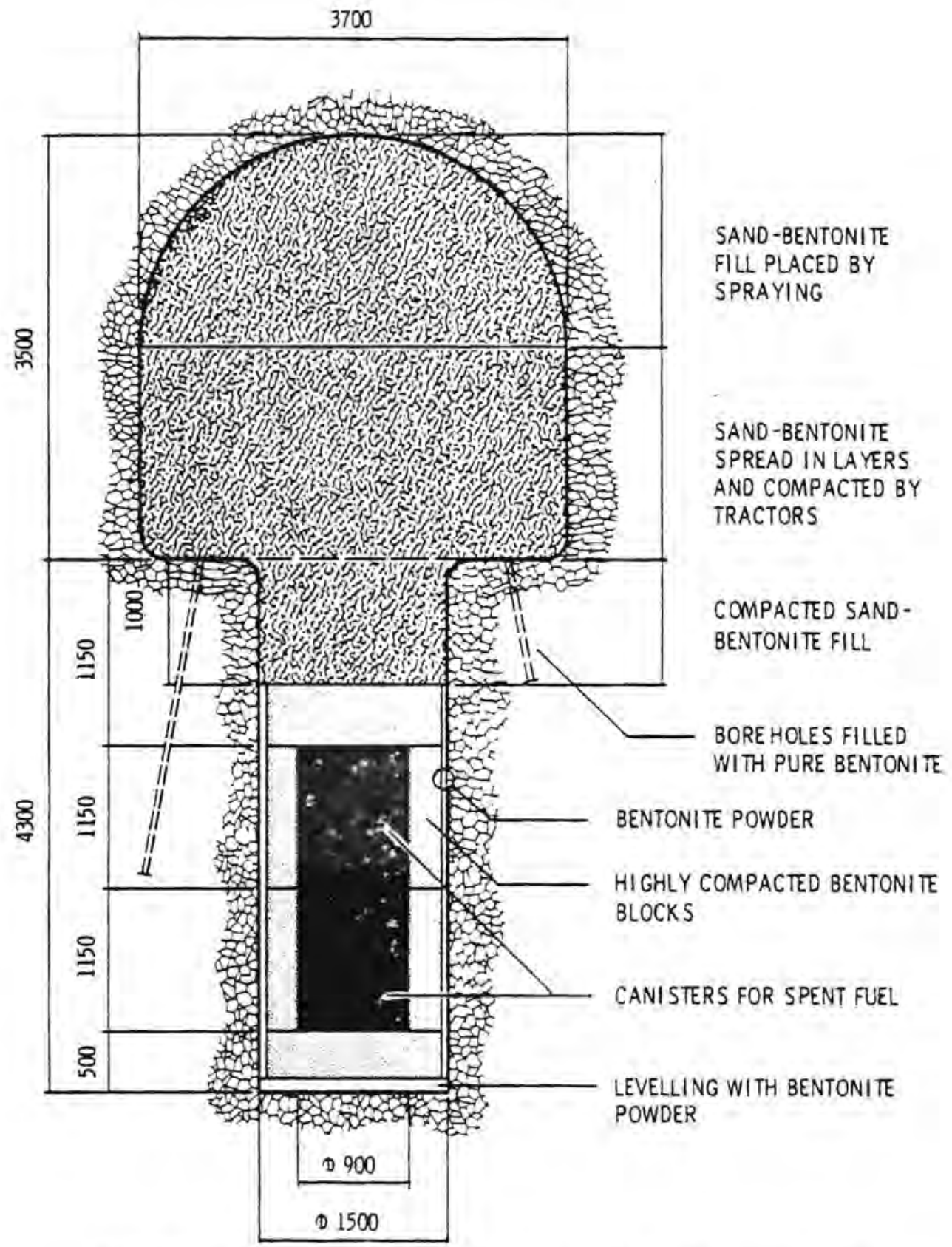

FIGURE 5. Section Through Disposal Tunnel for Spent HWR Fuel After Sealing. Dimensions in mm. 
shown in Figure 6 . A 11 fue 1 cycles give rise to some form of medium- and low-level waste (MLW and LLW), which is packed in drums and placed in the repository with backfill as shown in Figure 7. Further data on canister and bentonite dimensions, canister shape, canister content and canister thermal loading are given in Table 3 .

Repository-Caused Perturbations

The creation of a repository containing wastes will cause several perturbations from the natural conditions, but the repository is designed to minimize the ir impact. The removal of rock for emplacement of wastes creates new hydrologic paths and openings which, because of the low extent of plastic deformation, will not close. Negative effects are minimized by orienting tunnels properly and by backfilling the tunnels and openings. The bentonite-sand or compacted bentonite swells upon absorbing natural rock waters.

Heat-induced effects on the geohydrology are minimized by proper heat loading considerations based on the conductivity and heat capacity of the rock, along with the waste spacing. For the thermal loading expected in the repository the temperature excursions are given in Figures 8 and 9 for spent fuel and vitrified waste, respectively.

Other repository-induced changes involve radiolysis, oxidation and temporary depression of the ground-water table around the repository. Radiolysis has a very local effect owing to the shielding provided by the rock.

Opening of the subsurface repository may cause temporary oxidation in the drained volumes of rock near the repository. Oxidation during this phase is comparable to that induced by underground mining. Published studies (12) indicate that this effect is very limited. It cannot be expected to endanger the barrier action of reductive precipitation further along the flowpath of the ground water.

While the repository is accessible, the direction of the ground-water flow will be towards it and no outward migration of nuclides can take place. During this period good possibilities are at hand to detect and thus modify eventual inflow of ground water. 


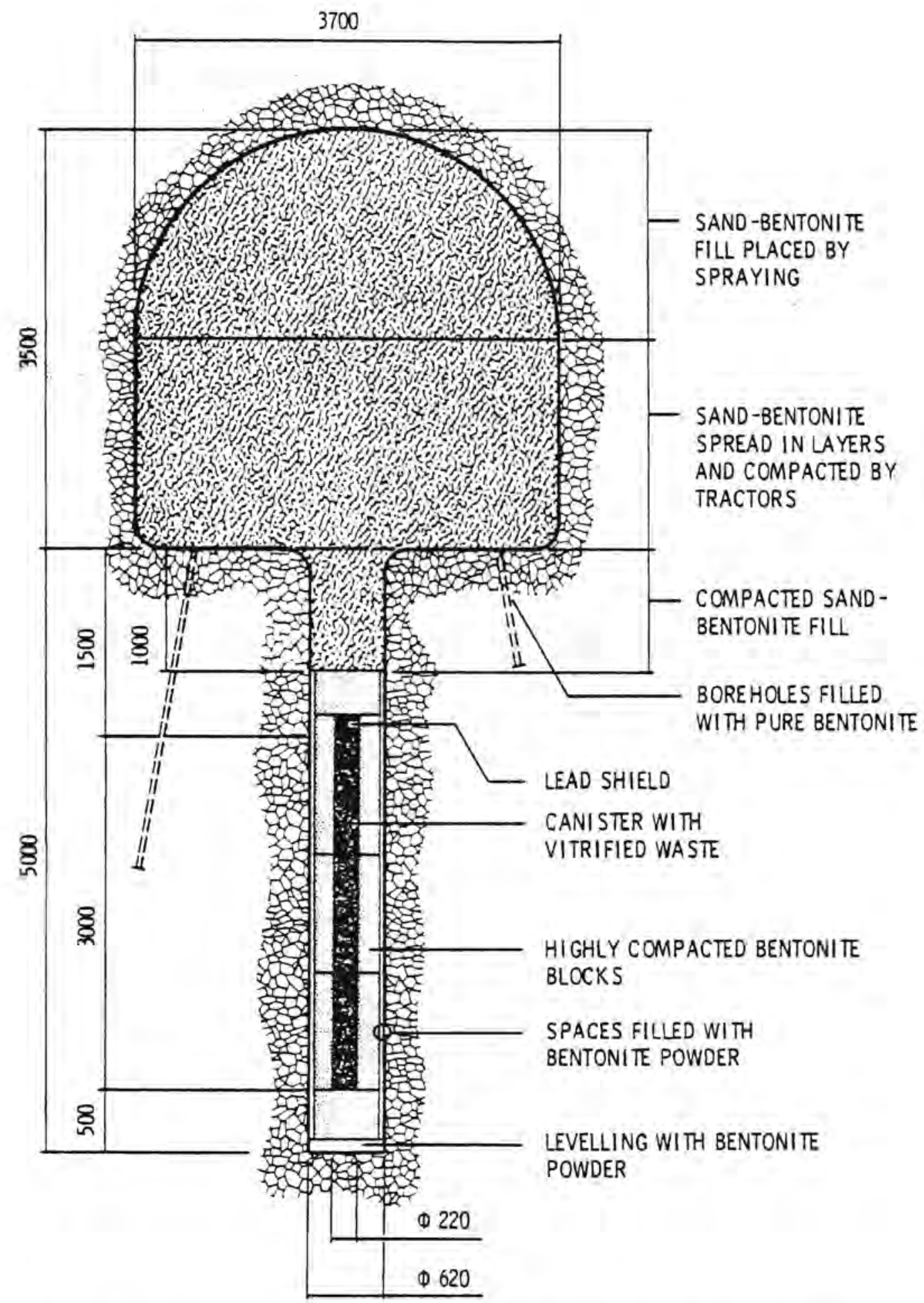

FIGURE 6. Section Through Disposal Tunnel for Vitrified HLW Canisters After Sealing. Dimensions in $\mathrm{mm}$. 


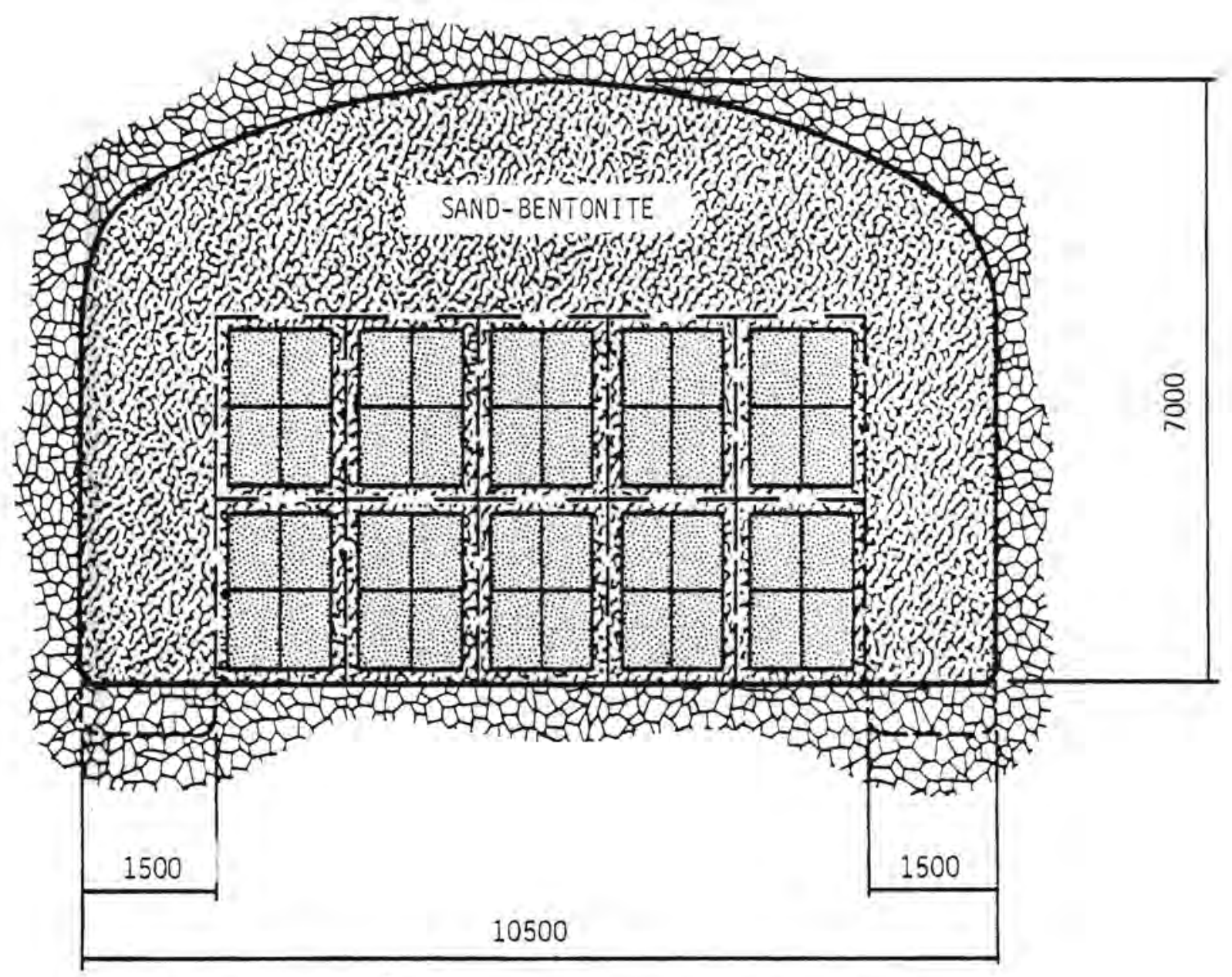

FIGURE 7. Section Through Disposal Tunnel for Drums with MLW and LLW After Sealing. Dimensions in $\mathrm{mm}$.

Inventory

For both INFCE studies the nuclear inventory to be stored in the repository for fuel cycles 1 and 4 is spent fuel (once-through), and for cycles 2, $3,5,6$, and 7 is the high-level vitrified waste associated with recycle. Wastes (except mining and milling) from 1 year of a 100-GWe nuclear economy are placed in the repository. The detailed inventory for each INFCE fuel cycle was obtained from the flow sheet data on the fuel cycles and isotopic content information contained in Reference 13. 
TABLE 3. Waste Package Descriptions

\begin{tabular}{|c|c|c|c|c|c|c|c|c|c|}
\hline $\begin{array}{c}\text { Package } \\
\text { Type }\end{array}$ & $\begin{array}{l}\text { Package } \\
\text { Material }\end{array}$ & $\begin{array}{r}\text { Haste Type } \\
\text { Concalned } \\
\end{array}$ & $\begin{array}{c}\text { External } \\
\text { Diancter. } \\
\text { to }\end{array}$ & $\begin{array}{c}\text { Internal } \\
\text { Dlameter, } \\
\text { m (approx.) }\end{array}$ & $\begin{array}{l}\text { Length of } \\
\text { Cantster, m }\end{array}$ & $\begin{array}{c}\text { Volume of } \\
\text { Haste } \\
\text { Contalned, } \\
m^{3}\end{array}$ & $\begin{array}{c}\text { Heavy } \\
\text { Mecals, } \\
\text { con (UtPu) }\end{array}$ & $\begin{array}{c}\text { Mhickness } \\
\text { of Bentonite } \\
\text { Sleeves } \\
\text { m }\end{array}$ & $\begin{array}{l}\text { Thermal Load } \\
\text { (10-year-old } \\
\text { waste) } \\
\text { kw/cantster }\end{array}$ \\
\hline Canister PWR & $\begin{array}{l}\text { Staluless } \\
\text { steel with } \\
\text { lead back- } \\
\text { fill }\end{array}$ & $\begin{array}{l}\text { Spent PWR fuel } \\
\text { assemblies. } \\
\text { Control rods. }\end{array}$ & 0.35 & 0.32 & $4.90-5.10$ & $\begin{array}{c}1 \text { PWR } \\
\text { element }\end{array}$ & 0.45 & 0.30 & 0.55 \\
\hline Candscer BWR & $\begin{array}{l}\text { Stainless } \\
\text { steel with } \\
\text { lead back- } \\
\text { fill }\end{array}$ & $\begin{array}{l}\text { Spent BWR fuel } \\
\text { dEsemblies. } \\
\text { BWR control } \\
\text { rods }\end{array}$ & 0.44 & 0.41 & 4.90 & $\begin{array}{c}1 \text { BWR } \\
\text { elewents }\end{array}$ & 0.54 & 0.30 & 0.55 \\
\hline Canister HWK (a) & $\begin{array}{l}\text { Stalnless } \\
\text { steel with } \\
\text { lead back- } \\
\text { f11l }\end{array}$ & $\begin{array}{l}\text { Spent link fuel } \\
\text { assemblies. } \\
\text { llulls, spacers, } \\
\text { Inaulubles. } \\
\text { ML. from } \\
\text { reprocesing. }\end{array}$ & 0.90 & 0.86 & 1.15 & $\begin{array}{c}72 \text { UWk } \\
\text { assembl 1es } \\
\left(0.6 \mathrm{~m}^{3}\right)\end{array}$ & 1.35 & 0.30 & 0.30 \\
\hline Candster HLW & $\begin{array}{l}\text { Stanlucus } \\
\text { steel }\end{array}$ & Vitrified HLW & 0.22 & 0.20 & 3.00 & $\begin{array}{l}0.077 \\
\text { (niet vol.) }\end{array}$ & & 0.20 & 0.50 \\
\hline $\begin{array}{l}\text { Drum, } \\
\text { slipeided }\end{array}$ & $\begin{array}{l}\text { Carbon } \\
\text { steel and } \\
\text { concrete }\end{array}$ & MLW & Varlable & & Varlable & 0.20 & & & \\
\hline
\end{tabular}

(a) Note that the cantoter "type UWR" is not only used for waste from the uWH cycle, but also for some waste from other cycles. 


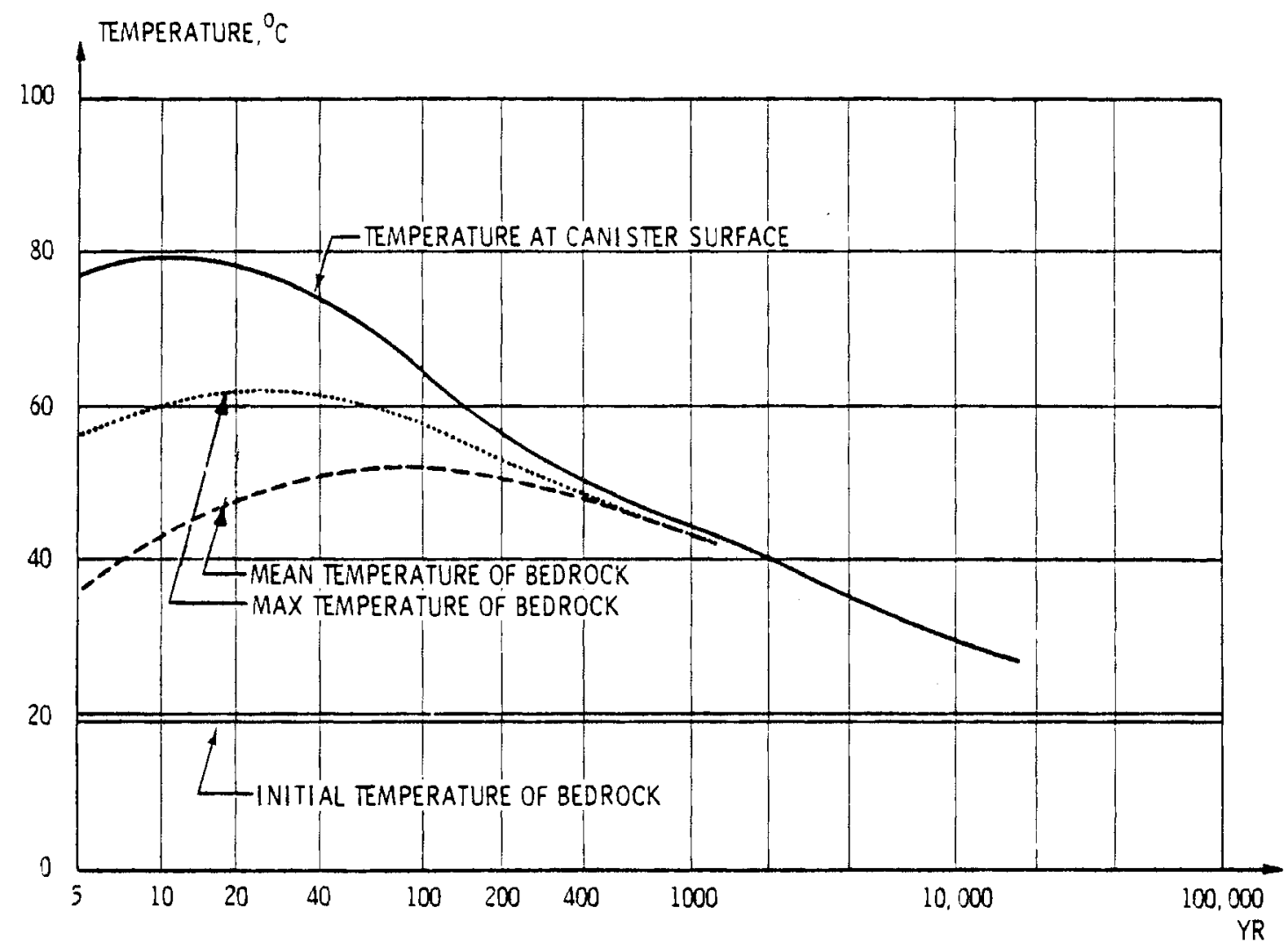

TIME AFTER OISPOSAL

FIGURE 8. Temperature at the Canister Surface and in the Bedrock as a Function of Time After Disposal. Spent Fuel (PWR).

\section{INFCE SALT REPOSITORY}

The general design of the INFCE sait repository is similar to the granite repository's. The hypothetical repository in salt is $600 \mathrm{~m}$ below the surface. One year of waste produced by a nuclear economy operating at 100 GWe/yr for 1 year would require 50 to 60 ha for all reactor strategies, (14) or 20 to 25 tunnels to store all high-, medium- and low-level waste. The nuclear inventory is the same as that discussed for granite above. 


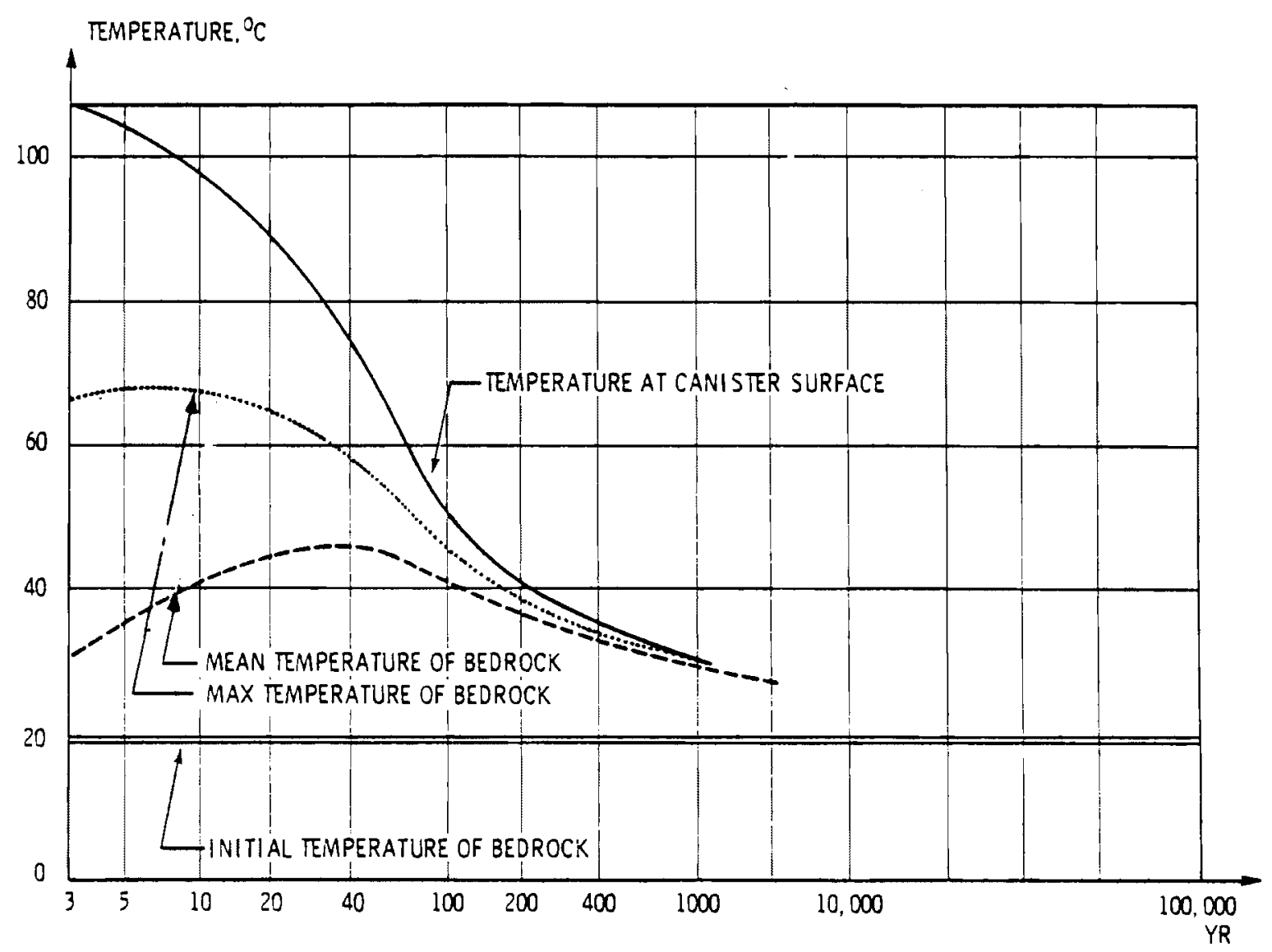

TIME AFTER DISPOSAL

FIGURE 9. Temperature at the Canister Surface and in the Bedrock as a Function of Time After Disposal. High-level waste $(H L W)$. (For repository geometry see Figure 6.)

\section{PARADOX BASIN REPOSITORY}

The conceptual repository for the Paradox Basin is similar in general design to the above. It is rectangular, 10,428 ft long and $8148 \mathrm{ft}$ wide, and contains 98 disposal tunnels on 78.83-ft spacing. Each disposal tunnel contains 1000 metric tons of heavy metal (MTHM), for a total capacity of 9800 MTHM. The inventory is spent fuel, and values for the isotopic content are taken from Reference 15. 


\section{HAINESVILLE REPOSITORY}

The basic conceptual design for a repository in a salt dome is similar to those discussed above, but the actual geometry of a repository is controlled by the shape of the dome at the emplacement depth. The hypothetical Hainesville repository is essentially egg-shaped, allowing an $800-f t$ buffer zone of intact salt to surround the 1375 acres of tunnels that comprise the repository $1700 \mathrm{ft}$ below ground surface. The repository is designed to hold 152,000 BWR spent fue 1 assemblies and 108,000 PWR spent fuel assemblies. The isotopic content of these assemblies was supplied by Bechtel National, Inc., and is similar to that used in the Paradox study. 
. 


\section{REFERENCE SITE DESCRIPTIONS}

Four reference repository sites are described below. The first three sites are for repositories in salt formations, and the fourth site is for a repository in granite. The three salt studies discussed are the INFCE Salt Study, ${ }^{(1)}$ the Paradox Basin Study, ${ }^{(3)}$ and the Hainesville Study. ${ }^{(4)}$ The fourth study is the INFCE Hard Rock (Granite) Study. (2)

Each site is located in a stable region without excessive tectonic stresses. The region has a low seismic level, being remote from recorded or historic earthquakes of greater than "moderate" intensity. There are no faults of significance at or near the site. The region is devoid of any recoverable resources of interest such as oil, gas, or potash.

For each of the four release consequence analyses discussed, a synopsis is given illustrating the

- data available for the site

- release scenario selected

- hydrologic model

- rationale for selection

- results

- assumptions or models used for barriers and leaching

- transport mode1

- rationale for selection

- results

- dose code used and results.

GEOHYDROLOGIC DESCRIPTION OF SALT

For long-term geologic isolation of radioactive wastes, salt has many distinguishing characteristics that make it an excellent candidate host rock. These include relative abundance, ease of excavation, relatively high thermal conductivity, impermeability, very low water content, plasticity and selfsealing properties, and lack of fracturing. However, some potential disadvantages are its frequent proximity to oil and gas fields, the specific value of the salt itself, and the suitability for storage of other materials. Salt is 
also water-soluble and, in the presence of water, can be corrosive to materials such as steels that may be used in waste packages.

At the depths of interest for siting and constructing a repository, salt deposits are found throughout the world in two principal forms. One type is an undeformed, bedded, sedimentary formation, laid down as the result of natural evaporation of sea water from prehistoric oceans. Commonly called "bedded salt," this deposit is usually extensive laterally and restricted vertically. The first two repository sites described below are for bedded salt host rock. The other type of salt occurrence can be characterized as an extensive mass of rock salt upwardly intruded through and into overlying sedimentary strata as the result of overburden-induced plastic deformation of an extremely deep bedded salt formation. Commonly called "dome salt," this deposit typically is extensive vertically and restricted laterally. The third repository site described below is for a dome salt host rock.

The characteristics of salt that make it attractive for disposal of radioactive wastes are common to both bedded and dome salt deposits. The two types are considered equally suitable, with the choice of one over the other influenced more by the range of natural occurrence and the thrust of site exploration programs within a specific area.

Salt formations are found in sedimentary basins. Depending on the actual site and salt form (bedded or dome), these deposits are generally overlain by various sequences of sedimentary formations ranging from unconsolidated sands, gravels and clays through sandstones, limestones, and anhydrites. Underlying sequences are typically of the same character, but unconsolidated sequences are generally much less prevalent, or nonexistent. Figures 10,11 , and 12 illustrate the cross sections for the INFCE, (1) Paradox, (3) and the Hainesville $\mathrm{e}^{(4)}$ study areas, respectively. Climatic conditions vary from arid $(3,4)$ to wet and humid. $(1,2)$ Some of the sedimentary formations or sequences of these formations overlying or underlying the salt contain water but are generally not prolific aquifers. Water in these deeper underlying formations is typically of poor quality, with total dissolved solids generally above $100,000 \mathrm{ppm}$ to nearly saturated brine. $(1,3)$ Water in aquifer systems directly overlying these salt formations is generally more variable, ranging 


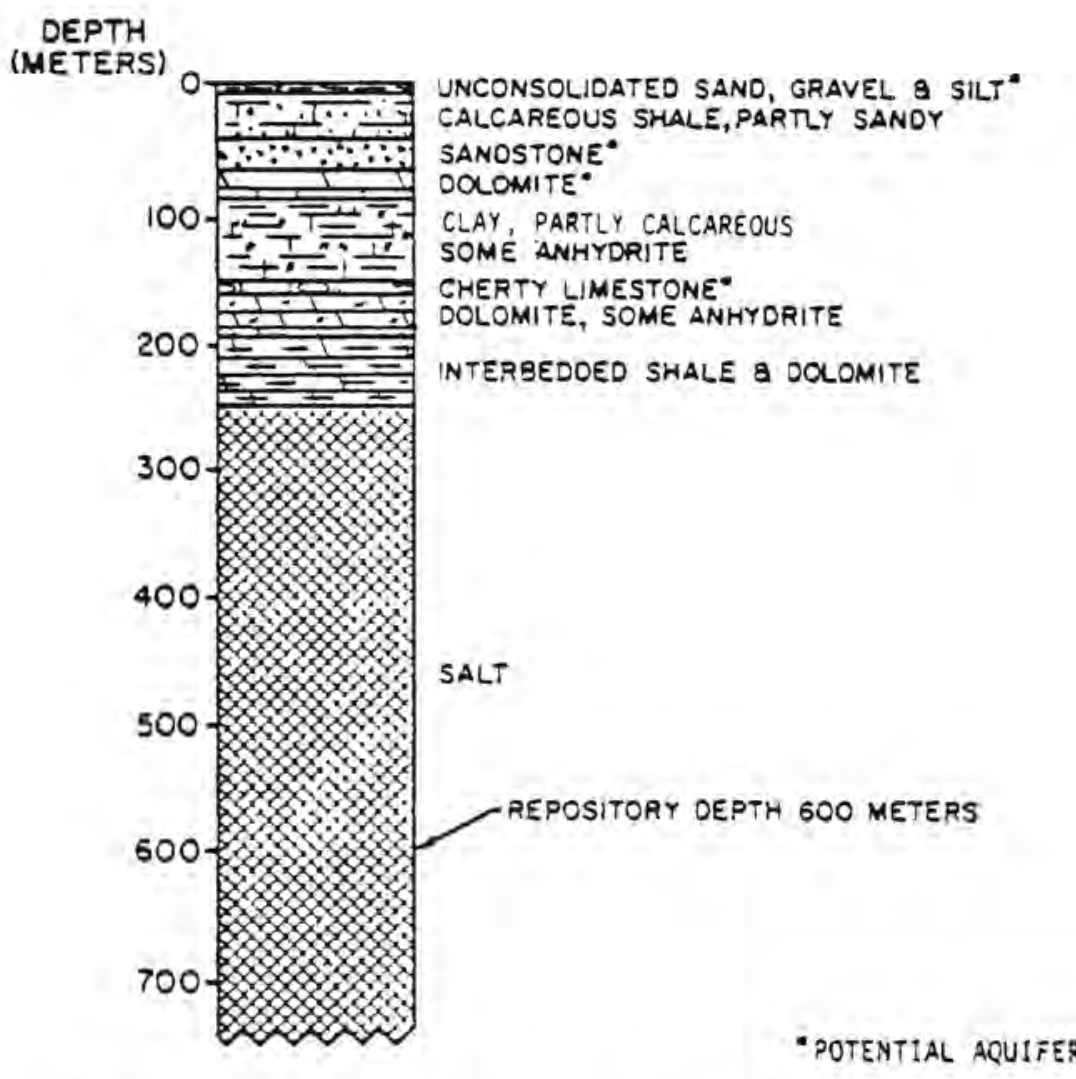

FIGURE 10. Representative Stratigraphic Section

from potable $e^{(2)}$ to brines $(1,3,4)$ of varying quality. Generally the salt. formation itself is surrounded by various forms of cap rock that act as aquitards to prevent water from dissolving the salt. The effectiveness and long-term stability of this seal is demonstrated by the existence of the easily dissolved salt formation.

Table 4 shows the geohydrologic parameters important to the effective iso1 ation of the three salt sites. Estimates of salt permeability $(1,15)$ values range from $2.0 \times 10^{-19}$ to $1.0 \times 10^{6} \mathrm{~m} / \mathrm{sec}\left(2.1 \times 10^{-15}\right.$ to $\left.1.0 \times 10^{-3} \mathrm{ft} / \mathrm{yr}\right)$, with an expected value of $2.0 \times 10^{-16} \mathrm{~m} / \mathrm{sec}\left(2.0 \times 10^{-12} \mathrm{ft} / \mathrm{yr}\right)$. Porosity is estimated at $0.2 .(1,15)$ More important than the geohydrologic properties of the salt are the properties of the overlying and/or underiying sediments. Typically the underlying sediments themselves provide no direct path to the 


\begin{tabular}{|c|c|c|c|c|c|c|}
\hline Bu & SYSTEM & SERIES & FORMATION & $\begin{array}{l}\text { THICXNESS } \\
f t\end{array}$ & LITHOLOGY & $\operatorname{Time}_{106}^{(B P)}$ \\
\hline 苋 & $\begin{array}{l}\text { QUATERMARY } \\
\text { ANO } \\
\text { TERTIARY }\end{array}$ & & $\begin{array}{l}\text { Unnamed Quatemary } \\
\text { Tert iary Intrusives } \\
\text { Was aten Formation }\end{array}$ & $0 . ?$ & $\begin{array}{l}\text { Quatemary and Tertiary fluyial and deolian } \\
\text { deposits; iertiary voleanies and intrusive } \\
\text { rocks; Grayel; tunes. }\end{array}$ & 0 \\
\hline \multirow{13}{*}{ 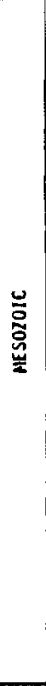 } & \multirow{5}{*}{ CRETACEWS } & \multirow{4}{*}{ UPPER } & Mes averde Grous & $0-500$ & Sandstore, siltstone, shale & \multirow[b]{5}{*}{135} \\
\hline & & & Mancos Shale & \multirow[t]{2}{*}{$1000-3500$} & Shale and siltstone & \\
\hline & & & Fertun memer & & Carbon if erous shale $F$ & \\
\hline & & & Dakota Sandstone & $100-150$ & Conglamerate, sandstone and shale & \\
\hline & & LOWER & Burro Canyon formation & $200-200$ & Conglamerate, sandstone and snale & \\
\hline & \multirow{5}{*}{ JLRASSIC } & \multirow{8}{*}{$?-?$} & $\begin{array}{l}\text { Morrison Formation } \\
\text { Brushy Bas in Memer } \\
\text { Salt Wash Memoer }\end{array}$ & $300-400$ & $\begin{array}{l}\text { Varicolored clarstone, siltstone and sandstone } \\
\text { Silitstone } \\
\text { siltstone }\end{array}$ & \multirow[b]{5}{*}{180} \\
\hline & & & Sumervilile formation & $25=100$ & Red shale and siltstone & \\
\hline & & & Entrada Sandstone & $100-500$ & Dune sams tone & \\
\hline & & & Cannel formation & $75-100$ & Red shale and siltstone & \\
\hline & & & Mave jo Sands tone & $100-400$ & Dune sanos tone & \\
\hline & \multirow{3}{*}{ TR LASSIC } & & Xayenta formation & $0-500$ & Red shale and sandstone & \multirow[b]{3}{*}{225} \\
\hline & & & Wingate Sands tone & $0-450$ & June sandstone & \\
\hline & & & $\begin{array}{l}\text { Chin le Formation } \\
\text { Moss } 8 \text { xck formation } \\
\text { Moenkooi formation }\end{array}$ & $? \cdot 2000$ & $\left.\begin{array}{l}\text { Red siltstone } \\
\text { Sandstone } \\
\text { Red shale and siltstone }\end{array}\right\} \begin{array}{l}\text { Dolores fm. } \\
\text { of Hite (1972) }\end{array}$ & \\
\hline \multirow{10}{*}{ 芯 } & PEDMIAN & & $\begin{array}{l}\text { White Rim } \\
\text { De Chelly } \\
\text { Organ Rock } \\
\text { Cedar Hesa } \\
\text { Halgat to }\end{array}$ & $\begin{array}{l}1500-2000 \\
300-500\end{array}$ & $\begin{array}{l}\text { Sandstone } \\
\text { Oune sandstone } \\
\text { Red shale and sandstone grading } \\
\text { intondstone } \\
\text { Red shale and siltstore }\end{array}$ & 270 \\
\hline & \multirow[t]{2}{*}{ PEMASTLyanian } & \multirow[t]{2}{*}{$\begin{array}{l}\text { YIRGIL: } \\
\text { MISSOMII } \\
\text { DES } \\
\text { MOINES } \\
\text { ATOKA- } \\
\text { MDRROH }\end{array}$} & Honaker ifall Fm. & $\begin{array}{c}1000-2000 \\
-\overline{0.6000}-- \\
-0-200\end{array}$ & Dolomite and black snale & \multirow[b]{2}{*}{305} \\
\hline & & & Molas Formation & 0.150 & Red shale, siltstone, - Juble (regollth) & \\
\hline & \multirow{3}{*}{$\begin{array}{l}\text { MISSISSIPPIM } \\
\text { DEWOMIAM }\end{array}$} & \multirow{3}{*}{---} & Leadville Limestone & $200-500$ & itmestone and solomite & 350 \\
\hline & & & $\begin{array}{l}\text { Ouray Limestone } \\
\text { Elbert Doionite } \\
\text { ecrocken Ss, Memper }\end{array}$ & $\begin{array}{l}75-100 \\
200-350\end{array}$ & $\begin{array}{l}\text { Limestone } \\
\text { Dolomite and Ifmestone with marine sandstone at hase }\end{array}$ & \\
\hline & & & Aneth boichit te & $0-200$ & Dolomite and ninor sandstone and shale & 400 \\
\hline & \multirow{4}{*}{ CATERIAM } & & Lyneh dotont te & $0-400$ & 3rom dolanite & \multirow[b]{4}{*}{500} \\
\hline & & & Maffieid Limestone & $?-660$ & Limestone snd shale & \\
\hline & & & Ophir Shale & 0.500 & Shale & \\
\hline & & & Ignac to Quartz ite & 0.200 & Quartzitic sandstone snd conglomerate & \\
\hline \multicolumn{2}{|c|}{ PRECAMERIAM } & & Unnoued & $18,000(?)$ & $\begin{array}{l}\text { Sediments and metasediments } \\
\text { schists, gneisses, qudrzzites, instrusives }\end{array}$ & \\
\hline
\end{tabular}

FIGURE 11. Generalized Geologjc Column of the Paradox 


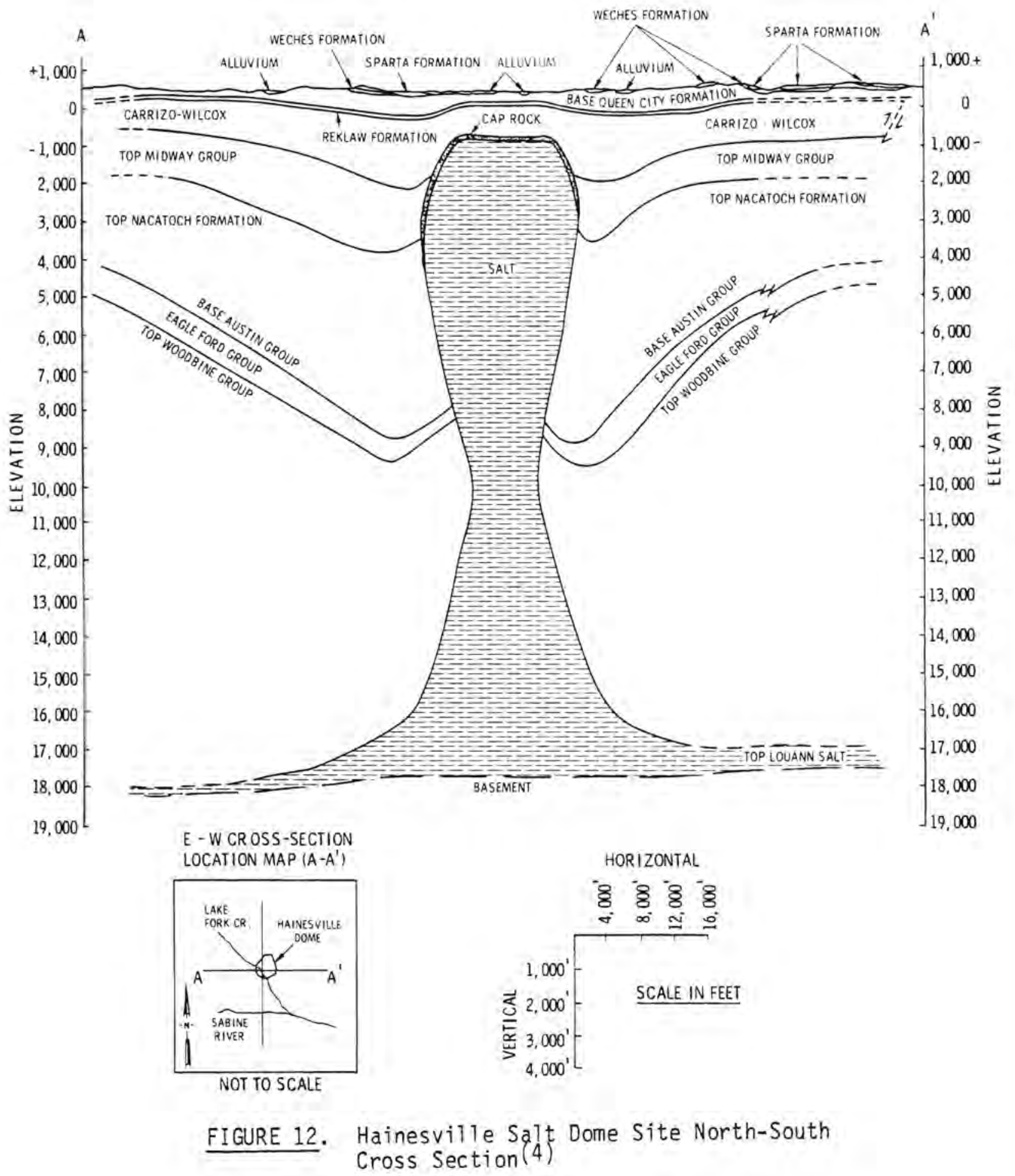


TABLE 4. Typical Values and Ranges in Hydrologic Properties and Parameters of the Sites

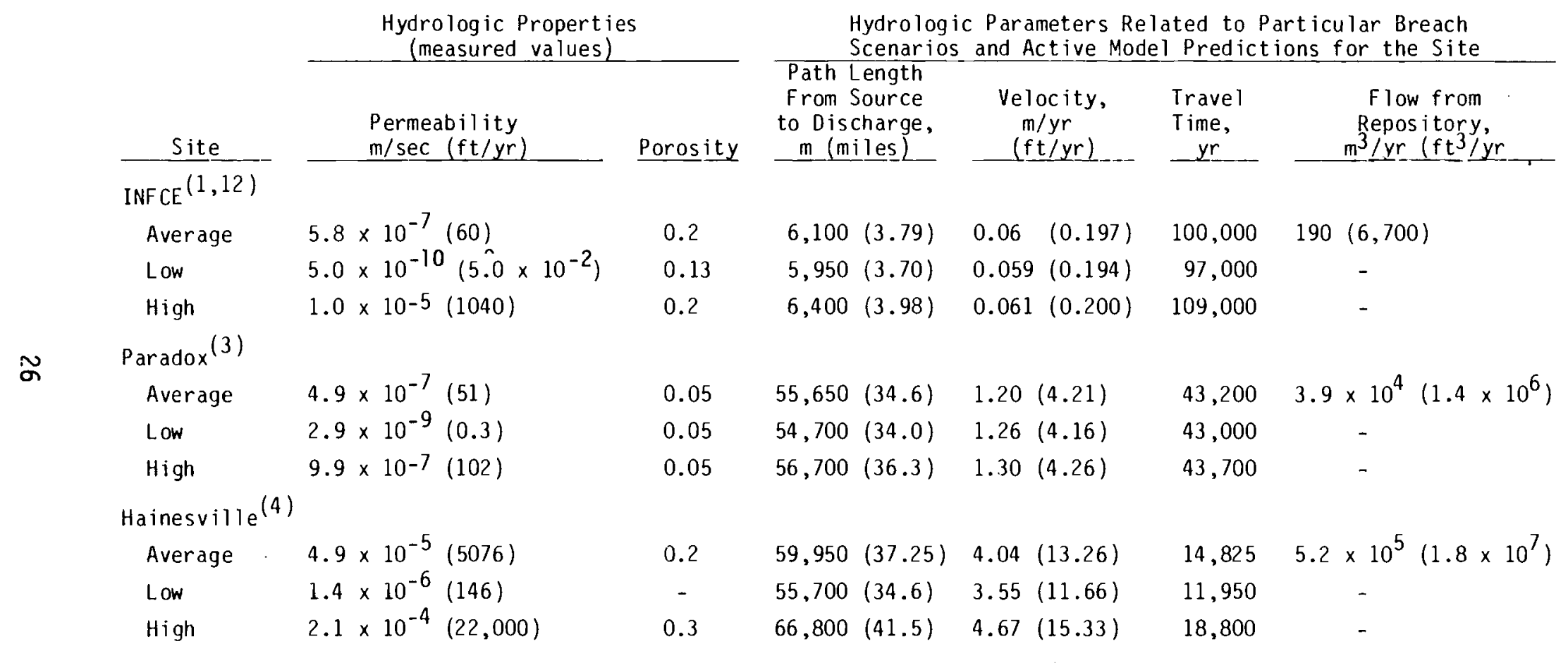


biosphere but instead interact with the overlying sediments to control the rate of water movement through the repository after a breach via borehole or other man-caused failure, $(4,5,6)$ or fracturing and faulting. $(1,3)$ only af ter the breach scenario and water flow path to the biosphere have been identified can the appropriate hydrologic characteristics for describing the travel time to the biosphere be identified. As shown in Table 4, the permeabilities along the flow path from the breached repository to the biosphere range from $5 \times 10^{-10} \mathrm{~m} / \mathrm{sec}(0.05 \mathrm{ft} / \mathrm{yr})$ to $2.1 \times 10^{-4} \mathrm{~m} / \mathrm{sec}(22,000 \mathrm{ft} / \mathrm{yr})$ and porosities from 0.05 to 0.3 . It is important to note that while permeability ranges over six orders of magnitude and porosity ranges over one order of magnitude along the travel path, the hydrologic model-predicted travel times range over less than one order of magnitude from 11,950 to 109,000 years.

\section{INFCE Salt Site}

The repository site for the INFCE Salt Study is assumed to be located in a 1 arge undeformed sedimentary basin. The top of the salt structure lies $250 \mathrm{~m}$ below the surface, and the structure extends indefinitely below this point. The sedimentary formations overlying the structure consist of about $250 \mathrm{~m}$ of interbedded shales, limestones/sandstones, anhydrites, and dolomites (Figure 10). The strata within the basin, particularly those overlying the salt structure, are nearly flat, with a small regional dip.

The strata overlying and surrounding the salt contain water, but are not considered prolific aquifers. In the limestone-dolomite-sandstone aquifer, the water is considered to be a brine and therefore will not dissolve the salt if it contacts it. The ground-water level is within a few meters of the surface, and the hydraulic gradient is about $1 \mathrm{~m} / \mathrm{km}$ for all aquifer systems. Table 5 lists the average permeabilities, range of permeabilities, and average porosities for each material in the various layers.

The regional discharge site for the water within the various layers (i.e., the biosphere uptake point for radioactive releases from the repository) is assumed to be a river. Figure 13 depicts the concept of a regional discharge 
TABLE 5. Hydrogeologic Parameters for Generic Salt Stratigraphy

\begin{tabular}{|c|c|c|c|c|}
\hline Rock Type & $\begin{array}{c}\text { Hydraulic } \\
\text { Conductivity, } \\
\mathrm{cm} / \mathrm{sec} \\
\end{array}$ & Range & $\begin{array}{c}\text { Porosity, } \\
\alpha \\
\end{array}$ & $\begin{array}{l}\text { Unit } \\
\text { Weight, } \\
\mathrm{kg} / \mathrm{m}^{3}\end{array}$ \\
\hline $\begin{array}{l}\text { Unconsolidated sand, } \\
\text { gravel, and silt }\end{array}$ & $6.8 \times 10^{-3}$ & $1 \times 10^{-7}-1 \times 10^{-2}$ & 20 & 1700 \\
\hline $\begin{array}{l}\text { Calcareous shale, } \\
\text { partly sandy }\end{array}$ & $1.2 \times 10^{-5}$ & $1 \times 10^{-10}-1 \times 10^{-3}$ & 13 & 2300 \\
\hline Sandstone & $8.1 \times 10^{-5}$ & $1 \times 10^{-10}-1 \times 10^{-2}$ & 20 & 2400 \\
\hline Dolomite & $8.1 \times 10^{-5}$ & $1 \times 10^{-10}-1 \times 10^{-2}$ & 20 & 2750 \\
\hline Cherty limestone & $5.8 \times 10^{-5}$ & $5 \times 10^{-8}-1 \times 10^{-3}$ & 20 & 2600 \\
\hline $\begin{array}{l}\text { Dolomite, some } \\
\text { anhydrite }\end{array}$ & $5.8 \times 10^{-5}$ & $5 \times 10^{-8}-1 \times 10^{-3}$ & 20 & 2800 \\
\hline $\begin{array}{l}\text { Interbedded shale } \\
\text { and dolomite }\end{array}$ & $6.8 \times 10^{-6}$ & $1 \times 1--10-1 \times 10^{-3}$ & 20 & 2500 \\
\hline Salt & $2 \times 10^{-18}$ & $2 \times 10^{-21}-1 \times 10^{-8}$ & 0.5 & 2160 \\
\hline
\end{tabular}

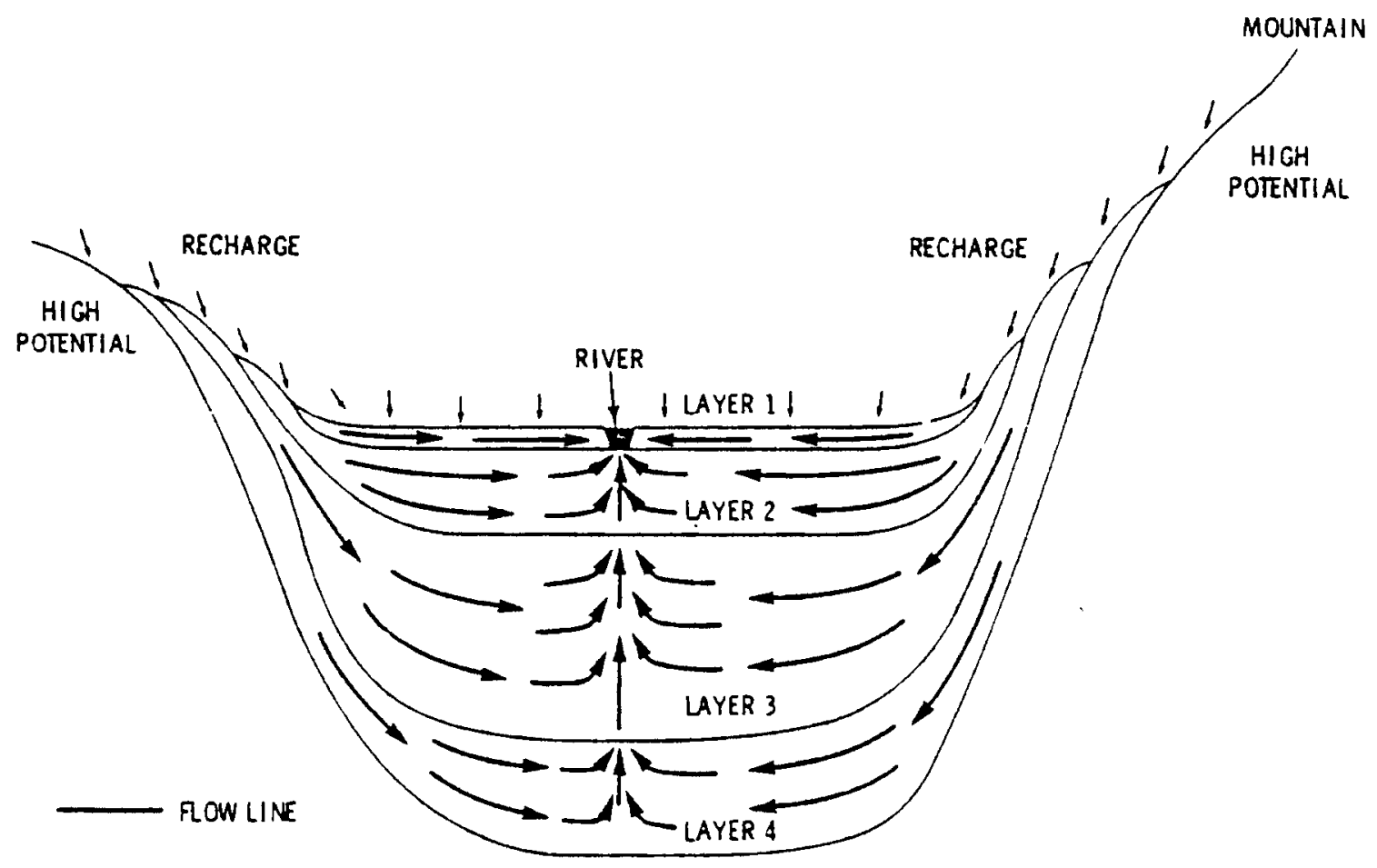

FIGURE 13. Cross-Section View of Regional Discharge to a River (vertical scale exaggerated) 
site and the associated upward movement of water to the river. The center of the repository was located $5 \mathrm{~km}$ from the river, a practical and probably conservative distance.

The salt structure's composition is alrnost pure halite, with only minor amounts of impurities occurring as isolated concentrations with well defined boundaries. The salt structure itself is sufficiently large to allow development of the repository workings to proceed without intercepting the concentrations of impurities.

\section{Paradox Basin Site}

The Paradox Basin bedded salt region, as used in the study, is defined at the surface by the zero isopleth of the Pennsylvanian salt beds. Commonly called the "zero-salt" line, this line circumscribes the outer perimeter of the salt, i.e., where salt thickness decreases to zero. About 10,000 square miles lie within the zero-salt line, of which about 6000 are in southeastern Utah and 4000 in southwestern Colorado. Figure 14, the location map for the region, shows the zero-salt line in a generalized form as defined by Wengard. (16) The salt beds exceed $4000 \mathrm{ft}$ in thickness at some locations within the region and provide the location for the hypothetical repository.

Figure 15 shows the base map of the model area within the Paradox Basin Region selected for the release consequence analysis. The model area lies between the Green and Colorado Rivers, extending about 100 miles northward from the confluence of the two rivers. Figure 15 also shows the location of the hypothetical repository about 35 miles north of the river junction. The repository is located more than $3000 \mathrm{ft}$ below ground surface in a thick section of interbedded salt and shale layers (Paradox Formation) that separate the upper and lower aquifer systems.

Table 6 shows the geologic formations that are present in the model area, their thickness, age, and role.

Figure 11 shows the relationship of the various formations in the generalized geologic column of the Paradox Basin bedded salt region. The Leadville 


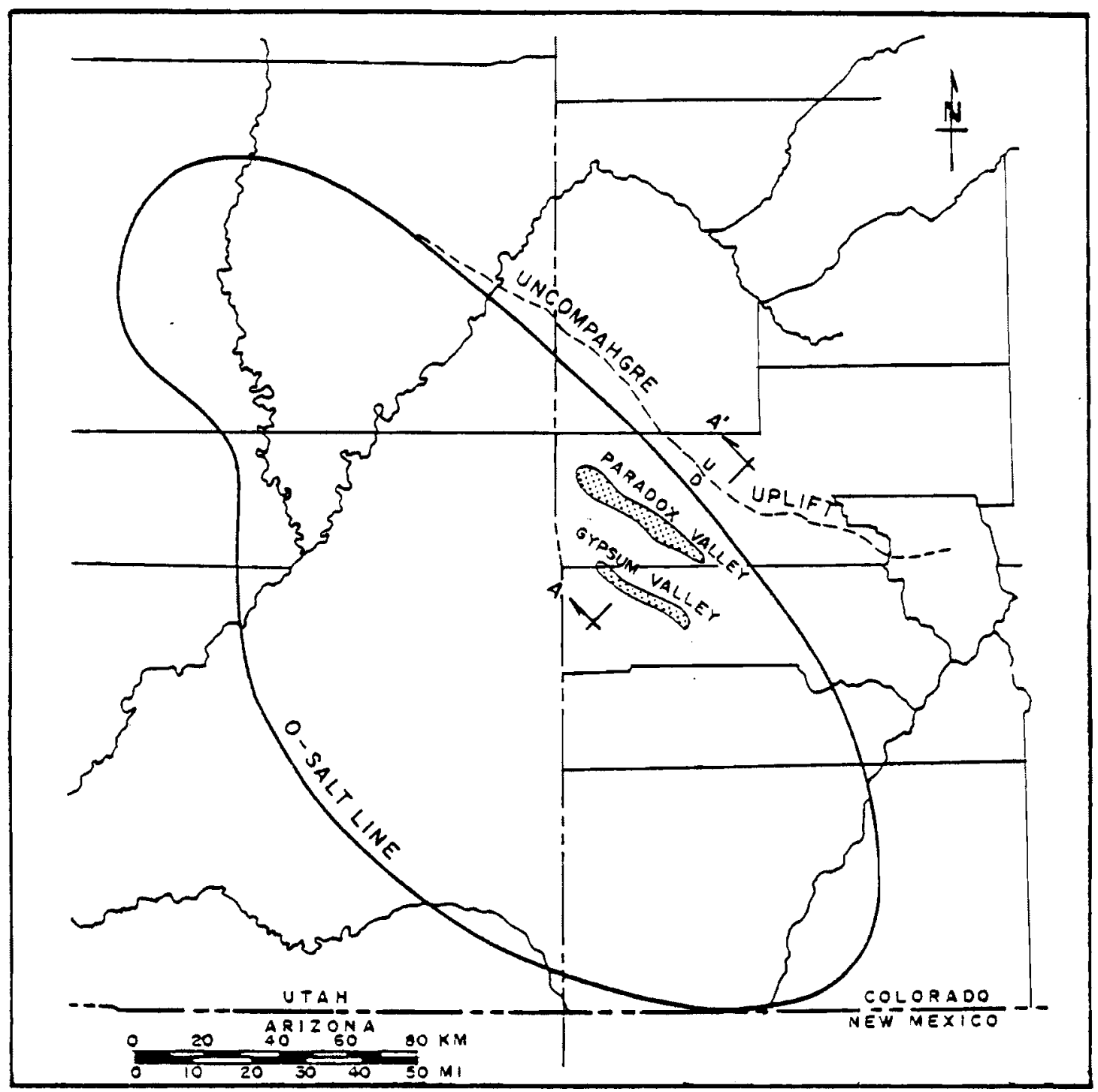

FIGURE 14. Paradox Basin Bedded Salt Region

limestone consists of limestone overlying dolomite. The limestone is dense, fine-grained, and massive, and the dolomite massive and coarsely crystalline. Fractures with in the formation provide its transmissive capabilities. The Molas Formation consists of calcareous shales and sandstone with lenses of limestone. The Pinkerton Trail Formation is mainly crystalline limestone and 


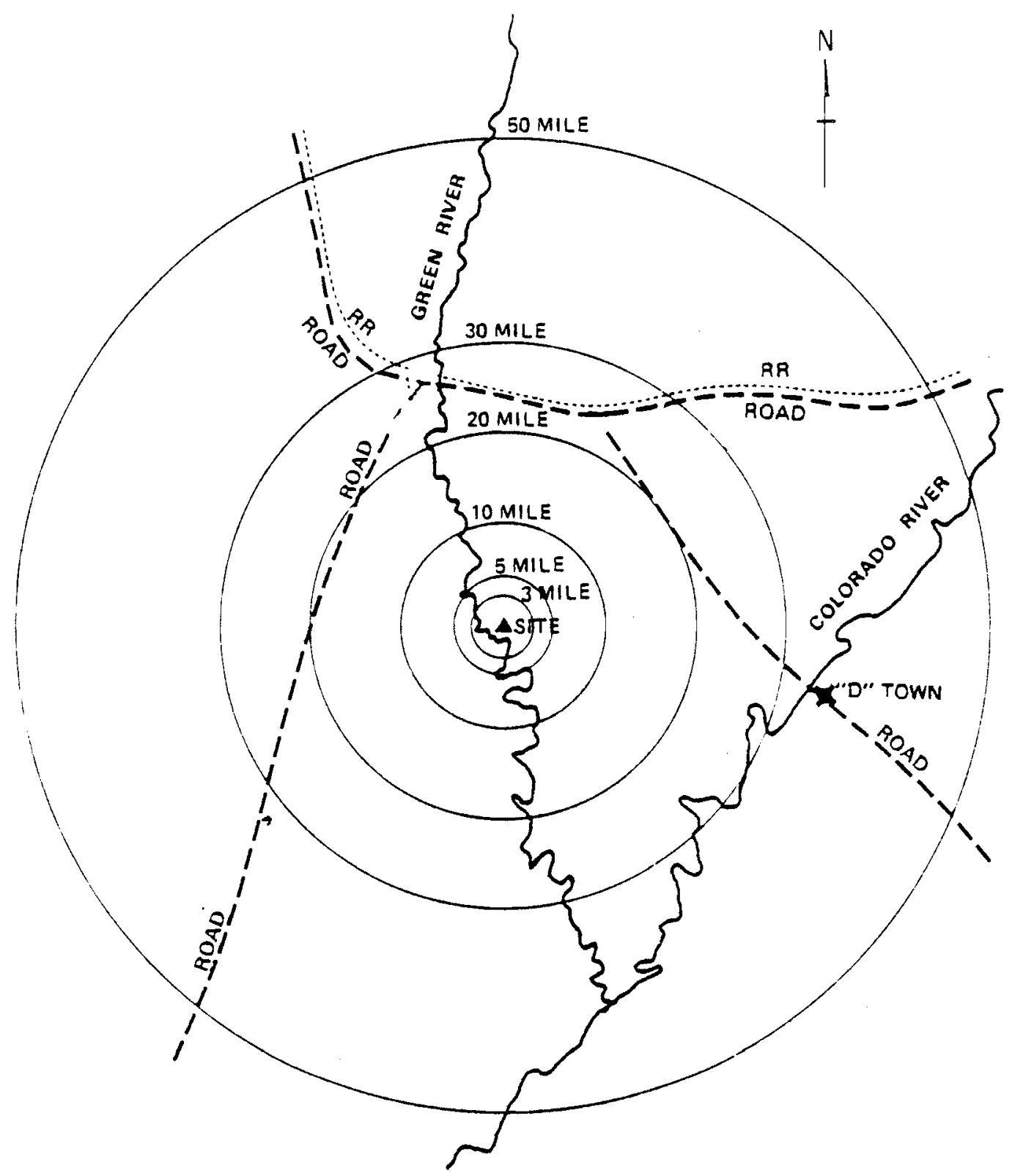

FIGURE 15. Base Map of the Paradox Model Region 
TABLE 6. Geologic Formations in the Paradox Modeled Area $(17,18)$

\begin{tabular}{|c|c|c|c|}
\hline Formation & $\begin{array}{c}\text { Thickness, } \\
\mathrm{ft}\end{array}$ & Geologic Age & Role \\
\hline 1. Moenkopi & 400 & Triassic & Aquiclude \\
\hline 2. Cutler & 200 & Permian & Upper Aquifer \\
\hline 3. Rico & 400 & Pennsylvanian & Upper Aquifer \\
\hline 4. Honaker Trail & 400 & Pennsylvanian & Upper Aquifer \\
\hline 5. Paradox & 4300 & Pennsylvanian & Aquiclude ${ }^{(a)}$ \\
\hline 6. Pinkerton Trail & 100 & Pennsylvanian & Aquiclude \\
\hline 7. Molas & 100 & Pennsylvanian & Aquiclude \\
\hline 8. Leadville & 500 & Mississippian & Lower Aquifer \\
\hline
\end{tabular}

(a) Location of hypothetical repository.

interbedded shale. The Paradox Formation in this area is mainly interbedded sodium salt, shale, and potassium salt beds. A salt anticline accounts for the unit's great thickness here. The Honaker Trail Formation is crystallineto-granular limestone with interbeds of chert and calcareous siltstone. Fractures within the formation provide its transmissive capabilities. The Rico Formation is interbedded sandstone, limestone, conglomerate and interbedded shale. The Cutler Formation is mainly cross-bedded sandstone with interbeds of siltstone, shale, and limestone. The Moenkopi Formation consists of shale, siltstone, and limestone. For the purposes of this exercise, the Moenkopi is assumed to be an aquiclude.

Potentiometric maps of the Mississippian (Leadville), Honaker Trail, and the Permian (Cutler) Formations (19) plus 30 oil well drill stem test analyses were used for this exercise. Twenty-five tests were analyzed in the Mississippian aquifer, three in the Paradox Formation, and one each in the Honaker Trail (Hermosa) and Permian Formations.

The potentiometric maps provided the hydraulic head and gradients of the upper and lower aquifer systems used in the hydrologic model. Additional 
information shows that little difference exists between the Honaker Trail and Permian potentials, indicating that the Rico formation does not act as a hydraulic barrier. Thus these three formations comprise the upper aquifer and the Mississippian Formation the lower aquifer. The potentiometric maps indicate that the potential of the lower aquifer ranges from 250 to $400 \mathrm{ft}$ above the upper aquifer potentials. Because a 250-ft head difference appears more common, it was used for this exercise. The potentials were corrected to fresh water densities. To avoid the local disruptions of the ground-water contours caused by faults in the north, the specific test site was located south of the faults.

The drill steam test data provided permeabilities and transmissivities of the two aquifers. Permeabilities in the lower system range from 0.4 to $190 \mathrm{ft} / \mathrm{yr}$. The average of this range, about $45 \mathrm{ft} / \mathrm{yr}$, was used for the initial runs of this exercise. For the upper aquifer the only permeability values available are 0.3 and $102 \mathrm{ft} / \mathrm{yr} ; 100 \mathrm{ft} / \mathrm{yr}$ was used for this exercise. Hainesville Site

The Hainesville salt dome is in the central part of Wood County in Northeast Texas (Figure 16), with the regional surface sloping generally from northwest to southeast. It is one of 26 salt domes in the Northeast Texas Salt Dome basin. Within 200 miles of Hainesville are four cities with a population of over 100,000--Dallas, Fort Worth, Shreveport, and Waco.

The sediments of the Northeast Texas Salt Dome basin record a series of marine transgressions and regressions, superimposed on a progradational depositional basin. The basin contains a very thick formation of Louann salt, and most structures in the basin are probably related to movements of salt from the Louann.

The Hainesville salt dome is the northernmost shallow piercement salt dome in the basin. Its site area consists of about 542 square miles of rolling hills. Within this area, the data used to characterize the dome include 11 wells penetrating the salt, one seismic reflection line, a basin gravity survey, and several wells near the dome. 


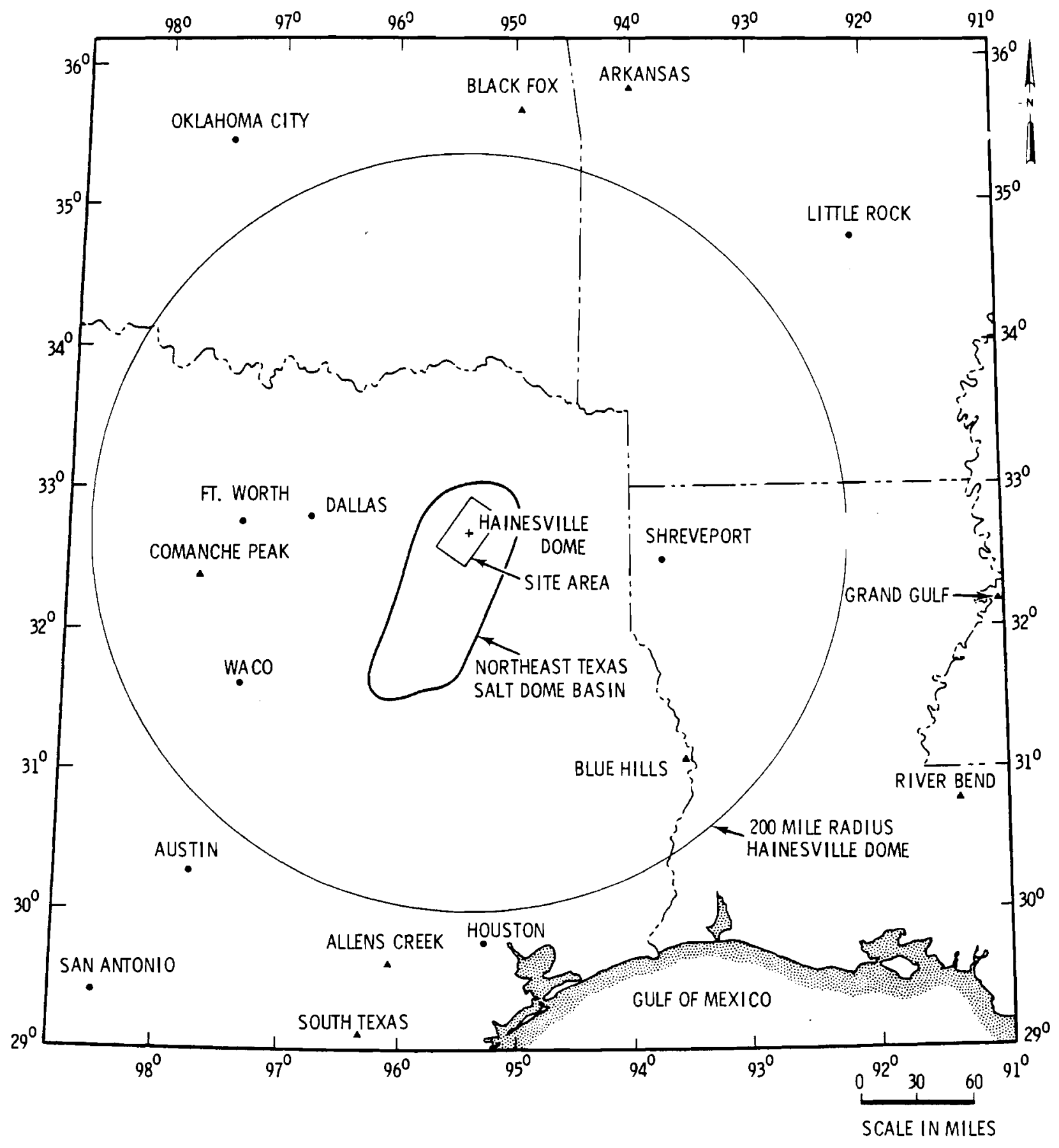

FIGURE 16. Hainesville Study Regional Location Map 
The dome pierces $16,000 \mathrm{ft}$ of strata, ranging from Late Jurassic to Early Tertiary in age (Figure 12 ). Cap rock is believed to cover the top of the dome, with thickness ranging from $50 \mathrm{ft}$ to more than $250 \mathrm{ft}$. This cap rock is composed of a top zone of pyrite, a middle zone of gray shaley limestone, and a lower zone of clear, very dense anhydrite. The dome itself is made of crystalline halite, with some evidence of shale inclusions on the periphery of the dome. At the repository depth, the dome is assumed to be about 2100 acres in cross section. Of this area, the repository would occupy about 1370 acres surrounded by an 800-ft buffer zone.

The hydrologic system in the vicinity of the dome consists of the following:

$\begin{array}{ll}\frac{\text { Geologic Unit }}{\text { Sparta Formation }} & \text { aquifer } \\ \text { Weches Formation } & \text { aquitard/aquiclude } \\ \text { Queen City Formation } & \text { aquifer } \\ \text { Recklaw Formation } & \text { aquitard/aquiclude } \\ \text { Carrizo Formation } & \text { aquifer } \\ \text { Wilcox Group } & \text { aquifer } \\ \text { Midway Group } & \text { aquiclude }\end{array}$

The Midway extends well below the repository level, and all aquifers below the Midway are saline. Thus lower aquifer systems were not considered important in the preliminary safety analysis because they are not likely to be used by humans or come in contact with the repository waste.

As the Weches is an incomplete barrier between them, the Sparta and Queen City Formations were taken to be a single unit. Similarly, the Carrizo and Wilcox are treated as a single unit. The Wilcox-Carrizo aquifer is the most important aquifer in the study area. Most of the larger municipalities and industries in the region obta in their water from this aquifer. Moreover, this aquifer surrounds the dome at repository depth. 
The Wilcox-Carrizo is very thick, so that it has a moderate transmissivity despite the relatively low hydraulic conductivity of its sands. Pumping tests conducted in the aquifer in Wood County from eight wells indicated the following characteristics:

$\begin{array}{ll}\text { Transmissivity } & 600-19,000 \mathrm{gpd} / \mathrm{ft} \\ \text { Well discharge rates } & 50-500 \mathrm{gpm} \\ \text { Spec ific capacities } & 0.8-9.7 \mathrm{gpm} / \mathrm{ft} \text { of drawdown } \\ \text { Hydraulic conductivity } & 4-700 \mathrm{gpd} / \mathrm{ft}^{2} \text { (50 gpd } / \mathrm{ft}^{2} \text { average) } \\ \text { Storage coefficient } & 0.00007-0.00027 \text { (unitless) }\end{array}$

\section{GEOHYDROLOGIC DESCRIPTION OF GRANITE}

Granite represents a viable host rock for a nuclear waste repository because of its many suitable characteristics. $(2,8,9,20,21)$ One of the most abundant rock types in the earth's crust, granite occurs at the surface in large, tectonically stable platform areas. In these areas the granite appears in rather monotonous, uniform geologic units, and at depth these units are generally poor sources of water. Granite masses have good mechanical strength that permits relatively safe and economical mining. Selection of sites where erosion has reached a mature stage will greatly decrease the probability of further erosion. Because granite masses rarely contain significant ore deposits, the chance of human intrusion is very slight.

Some potential disadvantages result from the presence of water at depth in granite and the rock's low thermal conductivity. The presence of water is generally of little concern because flow rates and velocities at repository depths are thought to be very low. The low thermal conductivity, while of concern, can be accommodated by proper emplacement design.

Flow in granite systems is dominated by flow in fractures. In these large areas of rock mass away from the discrete fracture zones, it is the degree and nature of the fracture's or joint's interconnection with other fractures or joints that determine the rock mass permeability. Since 
laboratory studies $(22,23)$ indicate that for single fractures hydraulic conductivity is a function of the aperture squared and the flux is a function of the aperture cubed, it is understandable that analysis of field data on permeability and porosity of hard rock systems suggests a logarithmic variation with depth. $(24,25)$ Fractures represent the most deformable component of crystalline rock, thus accounting for the rapid decrease in permeability and porosity with depth due to the increasing normal stresses.

Table 7 and Figure 17 illustrate the range of permeabilities for granitic and other crystalline rock that have been measured. Figure 18 illustrates the ranges in matrix porosity data that have been measured. (26)

In the INFCE study the porosities and permeabilities were assumed to vary linearly on a log-log plot of permeability or porosity with depth. Data cited on effective porosity measurements via various methods and for various granitic rocks $(8,9)$ indicate values for porosity between 0.028 and $0.001\left(\mathrm{~m}^{3} / \mathrm{m}^{3}\right)$. The three-dimensional ground-water flow modeling of the Finnsjo area of Sweden $(8,9,27)$ indicate that a $1 \mathrm{~km}^{2}$ repository would fit in an area where ground water takes longer than 3000 years to reach the surface. In these studies the hydraulic conductivity of the rock blocks dominated by flow through joint systems varied with depth according to:

$$
K=10^{-0.003} \mathrm{Z}-6(\mathrm{~m} / \mathrm{sec})
$$

where $Z$ is the depth in meters below the surface. The porosity value was constant in this study at 0.001 . The above variation of $k$ with depth corresponds to a value of $10^{-6} \mathrm{~m} / \mathrm{sec}$ at the surface and $10^{-7.5} \mathrm{~m} / \mathrm{sec}$ at $500 \mathrm{~m}$ below the surface. Discrete high-conductivity fracture zones that were included in the model had permeability vary as:

$$
K_{p}=10^{-0.003 \mathrm{Z}-4}(\mathrm{~m} / \mathrm{sec})
$$

where $Z$ = depth below the surface in meters.

It should be noted that the solid rock blocks in the massive areas, where the dominant flow is through joint systems, have permeabilities $<10^{-11} \mathrm{~m} / \mathrm{sec}$. Thus water that contacts waste emplaced in these nontransmissive solid rock 
TABLE 7. Degrees of Permeability of Various Rock Types

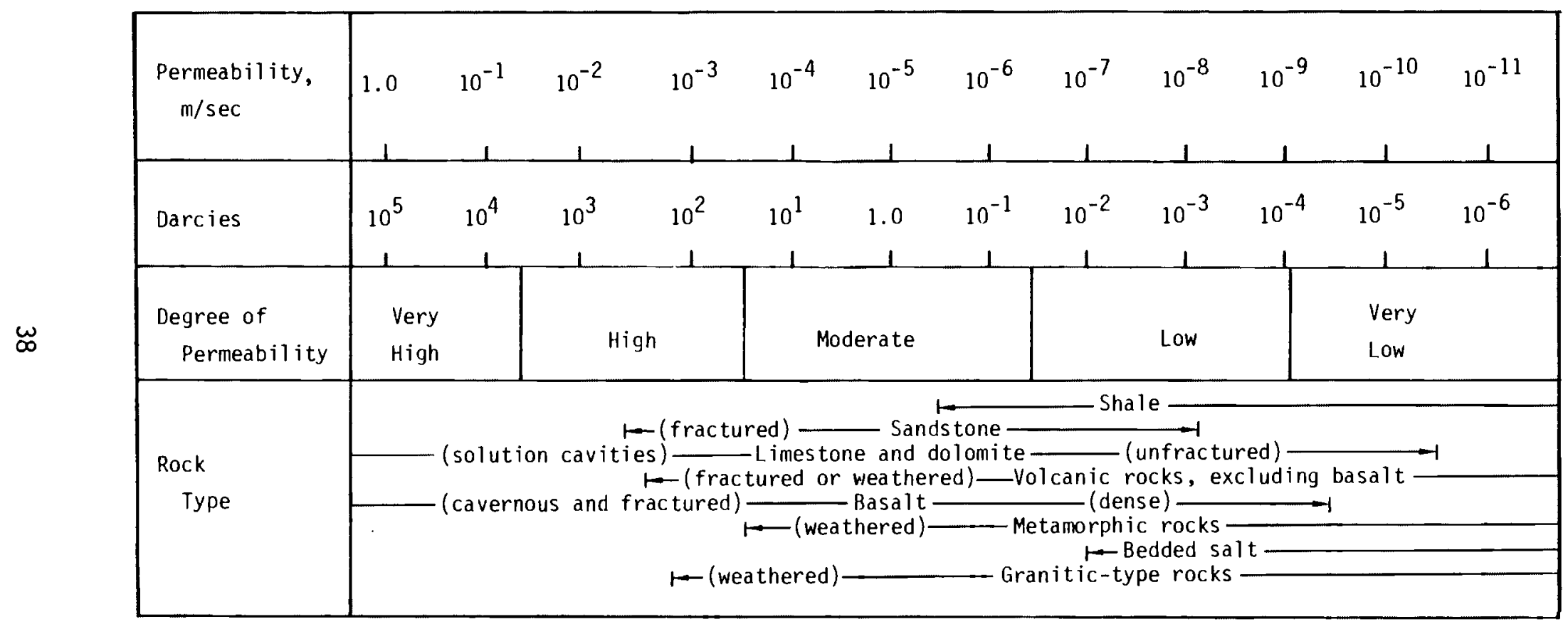




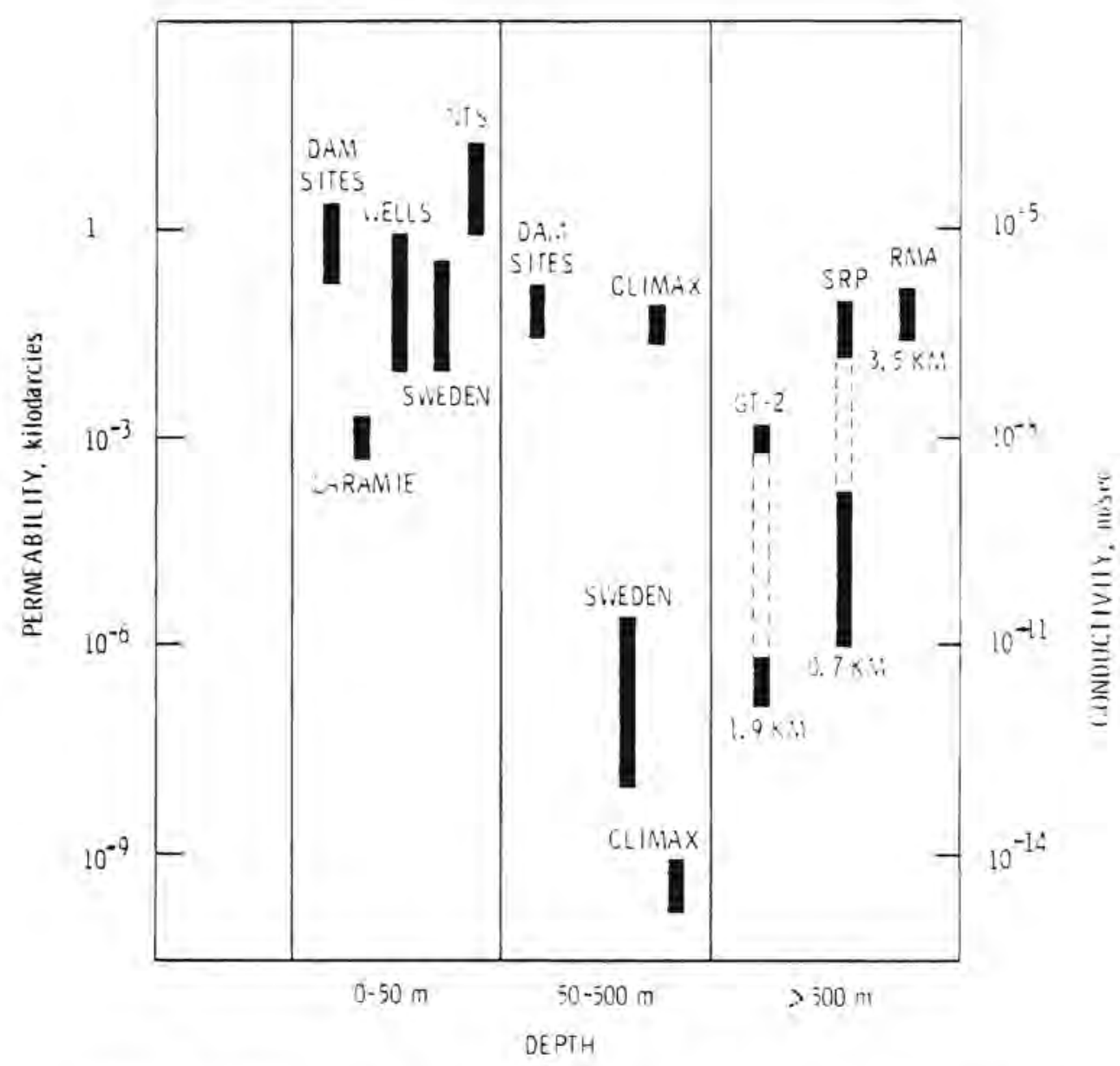

FIGURE 17. Ranges in Permeability for Crystalline Rock as a Function of Depth. (The ordinate in this figure is permeability-- in kilodarcies--or hydraulic conductivity--in $\mathrm{m} / \mathrm{sec}$. Bar for each site shows the range of measured values.)

blocks would have much greater travel times since water flow times through oniy a few meters of this nontransmissive rock can take thousands to hundreds of thous ands of years.

Data reported on ages of ground waters $(8,9)$ indicate a range of 3000 to 11,000 years for waters at an average depth of $380 \mathrm{~m}$ (average age of 5300 years). Some age determinations for waters from the Stripa Mine $(8,9)$ give values up to 30,000 years. These ages correlate well with the Swedish modeling study estimates. 


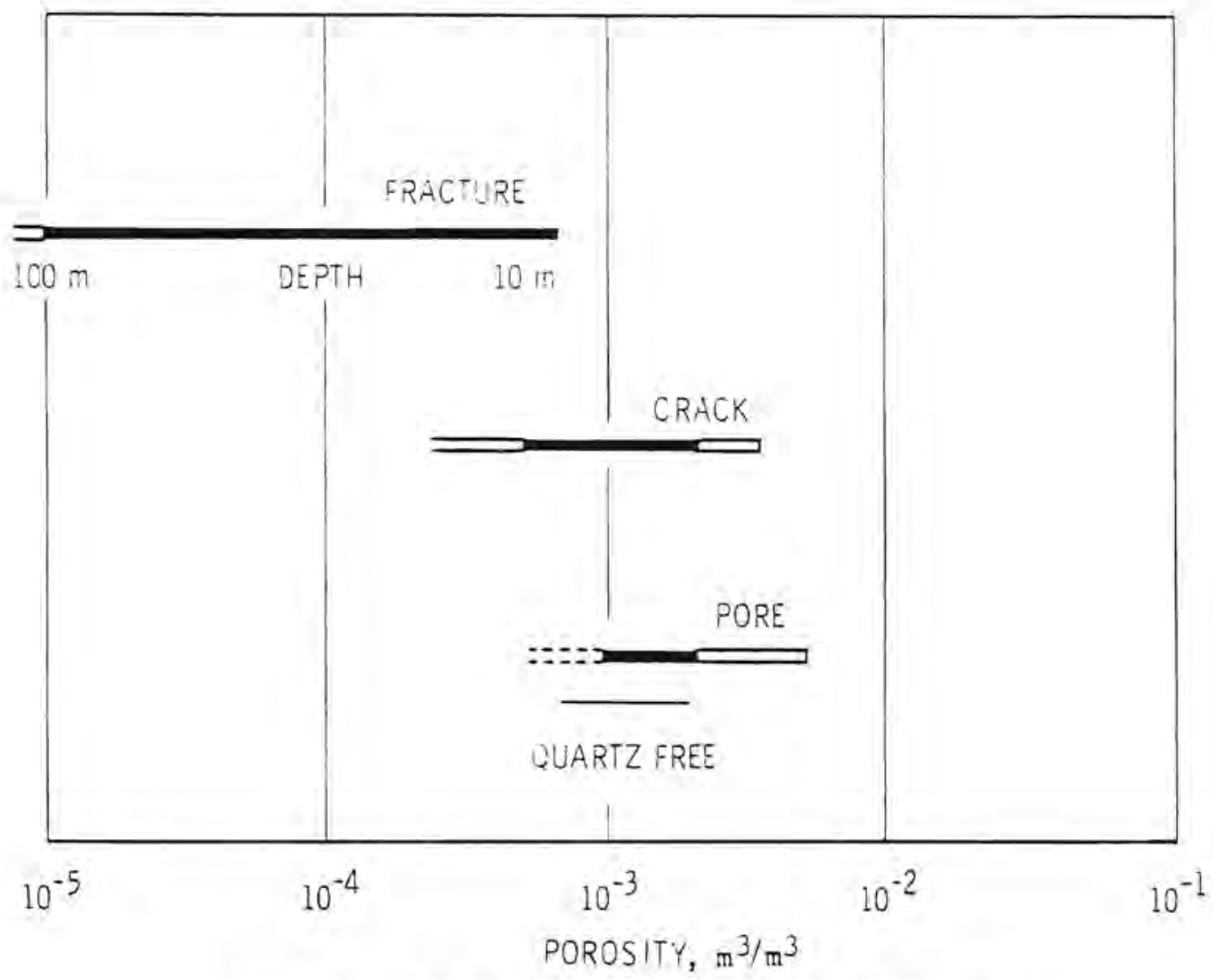

FIGURE 18. Variation in Three Types of Porosity

Another important factor in siting a waste repository concerns groundwater flow volumes. If flow volumes are small enough, even short travel times to the biosphere are of little importance since only trivial amounts of waste can be transported. Flow estimates from the INFCE study ${ }^{(2)}$ indicate a total flow rate through a $1-\mathrm{km}^{2}$ repository of on $1 \mathrm{y} 2.6 \mathrm{~m}^{3} / \mathrm{yr}$ or $\left(2.6 \times 10^{-3} \mathrm{l} / \mathrm{m}^{2}-\mathrm{yr}\right)$. This agrees with estimates for the Karlshamn area ${ }^{(8,9)}$ of $1.5 \times 10^{-3} \ell / \mathrm{m}^{2}-\mathrm{yr}$ at the repository level. Even at higher values for permeability and porosity, flaw values $<0.1$ to $0.15 \mathrm{l} / \mathrm{m}^{2}-\mathrm{yr}$ are obtained.

INFCE Granite Site

A subtask conducted under the INFCE committee was to evaluate and compare the health and safety impacts of nuclear waste management from seven different fuel cycles. For purposes of this study, all radioactive wastes (except 
mining and milling) were assumed placed in a geologic repository designed for hard crystalline rock. The reference repository for this study was in granitic rock or gneiss as the host rock.

For this study a generic site was considered that was assumed to be composed of relatively large areas of granite or gneiss consisting of solid rock blocks surrounded by small fracture planes or joints interconnected to some degree. This degree of interconnection gives rise to low permeability and porosity associated with these relatively large areas. These large areas of low permeability rock, dominated by flow through joint systems, are bounded by fractured zones which vary in length and width and need not be continuous throughout the rock mass. According to the stresses which now exist or caused these highly fractured zones, the first-and second-order tension zones were assigned widths of 50 and $10 \mathrm{~m}$, respectively. Shear zones and compression zones were assigned widths of 20 and $5 \mathrm{~m}$, respectively.

The values of permeability and porosity used in the INFCE release consequences analysis are shown in Table 8 . It is generally accepted that the hydraulic conductivity of these large areas of granite and gneiss, where flow is through joint systems, is $<10^{-11} \mathrm{~m} / \mathrm{sec}$ and that, therefore, significant flow can occur only through the bounding fractured zones. The hydraulic properties vary, depending on the stresses that produced these zones, the stresses currently acting on them, and the depth of the zone beneath the surface. In these hard rock systems permeability decreases logarithmically with depth because of the decrease in fracture aperture size resulting from compression produced by the overburden.

The area used in the hydrologic model is $25,000 \mathrm{~m}$ by $25,000 \mathrm{~m}$. Within the generic area, lakes, rivers, and topography are given as shown in Figure 19. A subdued version of the topography was used to represent the ground-water table elevations throughout the region. The ground-water divide to the south has an altitude of 40 to $45 \mathrm{~m}$ above the level of the sea to the north.

The granite site is assumed to be in a flat, low-lying, stable platform area where erosion has reached a mature stage. The surface consists of some surficial deposits of till and clay from a few meters to a few tens of meters 
TABLE 8. Hydraulic Properties of Different Hydrogeologic Structures for the Reference Repository Site Area in Granite

Water

Velocity Travel Time for (unit gradient), $1 \mathrm{~km}$ under 0.001

\section{Descr1ption}

Rock Mass

FIrst Order

Fracture Zones

$\stackrel{\leftrightarrow}{N}$

(tenston)

Second Order

Fracture Zones

(tension)

Second Order

Fracture Zones

(shear)

Second Order

Fracture Zones

(compression)
W1dth Depth

$1 \mathrm{~m}$

$500 \mathrm{~m}$

Permeab111ty.

$\mathrm{m} / \mathrm{sec}$

$$
\begin{aligned}
& 10^{-7} \\
& 10^{-10}
\end{aligned}
$$

1 . m

$500 \mathrm{~m}$

$10^{-5}$
$10^{-8}$

$1 \mathrm{~m}$

$.500 \mathrm{~m}$

$10^{-5}$
$10^{-8}$

$\begin{array}{rl}1 \mathrm{~m} & 5 \times 10^{-7} \\ 00 \mathrm{~m} & 5 \times 10^{-10}\end{array}$

$1.7 \times 10^{-3}$

$1 \times 10^{-4}$
$3 \times 10^{-5}$

317

20

$5 \mathrm{~m}$

$1 \mathrm{~m}$

159
$10^{-6}$
$10^{-9}$

$5 \times 10^{-3}$
$1.7 \times 10^{-5}$

$2 \times 10^{-4}$
$6 \times 10^{-5}$ 


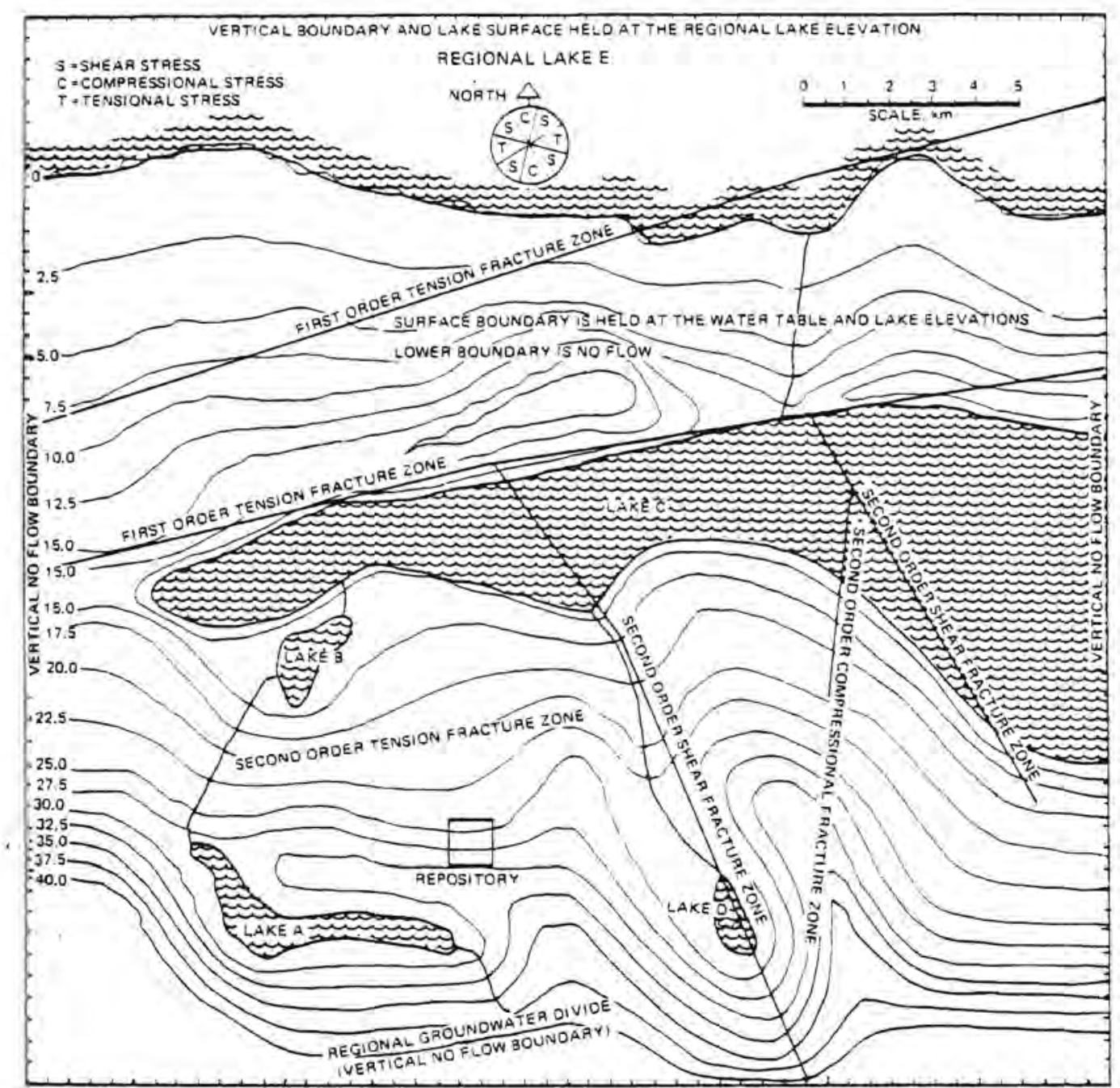

FIGURE I9. Reference Repository Site in Granite, I17ustrating Boundaries, Fractures and Water Table

in thickness. Beyond this upper layer of till with some areas of granite outcrop, the stratigraphy is granitic or gneissic. Regional tilt is on the order of $10^{-3} \mathrm{~m} / \mathrm{m}$ and $10 \mathrm{cal}$ topographic variations of $10^{-1} \mathrm{~m} / \mathrm{m}$. Hydrologic discharge sites consist of the lakes, rivers, and streams that drain the area. Recharge is typically from rainfall and possibly some lakes, rivers, and streams. The repository site would typically be located below recharge zones, such as a ground-water divide, that are as distant as possible from discharge 
sites. This would ensure that waters entering the repository would move downward through the repository into deeper, more regional circulation systems enroute to the biosphere.

The granite masses consist of solid rock blocks, containing only microfracture systems in or between mineral grains (permeability $<10^{-11} \mathrm{~m} / \mathrm{sec}$ ), surrounded by fracture planes or joints. These joints are discontinuous in their own planes, and flow in these rock masses is dominated by the flow in the more or less interconnected joint sets. Fractures or joints in these large rock masses generally are continuous over distances that are on the order of three to four times the average fracture spacing. These larger masses of rock, where flow is dominated by the joint systems, frequently contain more highly interconnected discrete fracture zones that can be identified via various geophysical methods. These fracture zones are generally much more permeable than the surrounding rock masses. These zones vary from a meter or so to tens of meters in width and hundreds to thousands of meters in length. The hydrologic properties of these discrete fracture zones is dependent on the stresses which formed these systems as well as the stresses which now exist in the rock masses. Shear zones, for example, are generally filled with broken or crushed rock and may be embedded in clay. Figure 20 schematically illustrates the fractured rock masses with joint systems and discrete fracture zones. While the microfracture systems in the solid rock blocks do not contribute significantly to the flow of ground water, they are important in the diffusion of nuclides from the active fractures and joints--they delay transport times. This "kinetic effect" is discussed by Neretnieks in Reference 28.

The upper portion of the granitic systems--which can sometimes extend from the surface up to a few hundred meters--is often characterized by higher permeabilities because of the more extensive and coherent network of fissures. With increasing depth there is a transition to larger spacings between fractures or joints that are less interconnected. Sites deep in the granite system, where the blocks of solid rock become more massive and are distant from major fracture and discharge zones, make excellent candidate repository sites. These massive blocks of solid rock ensure greater isolation. 


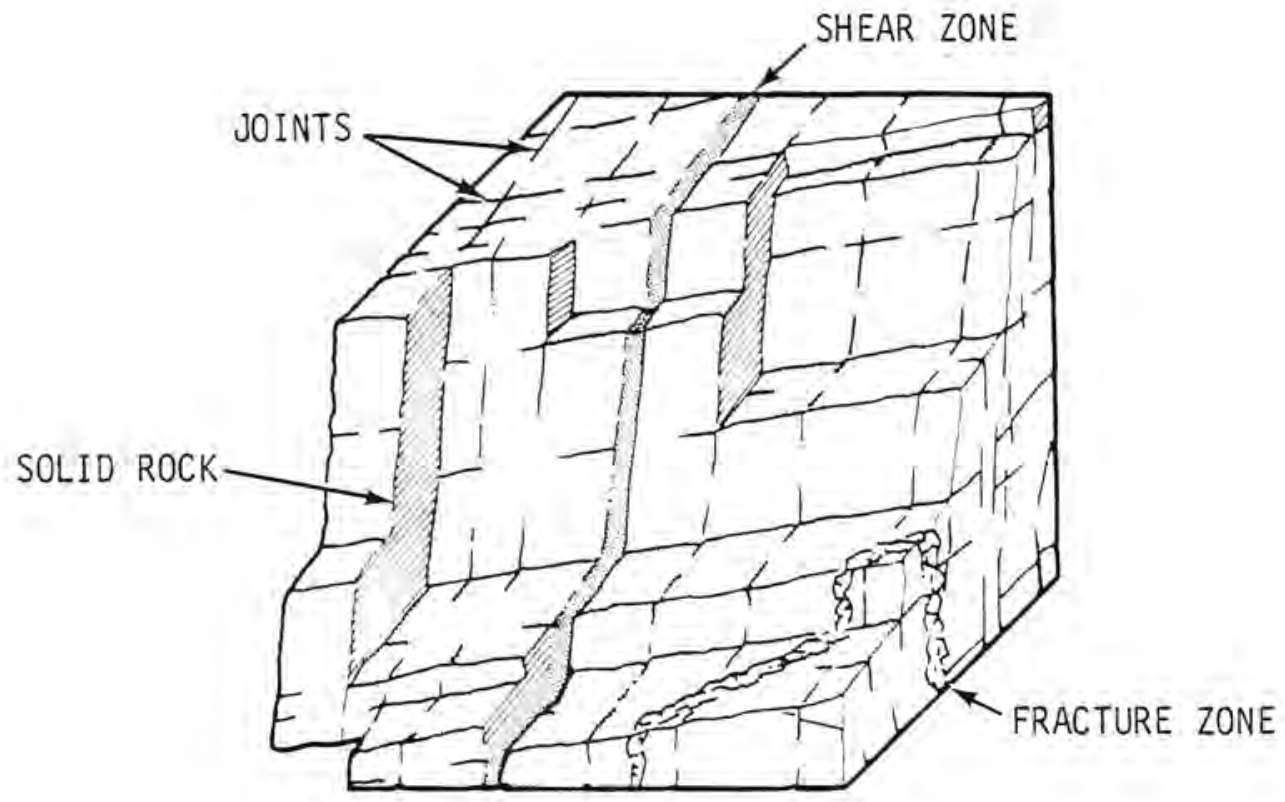

FIGURE 20. Schematic of Fractured Rock Mass 


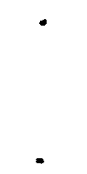




\section{RELEASE SCENARIOS}

The purpose of a release scenario analysis for a nuclear waste repository is to evaluate both geologic and man-caused events and processes in order to determine the impact they might have on the integrity of the repository. Events, such as earthquakes, faulting and human intrusion, and processes, such as erosion, uplift and diapirism, could, alone or together, significantly alter the geology surrounding the repository and lead to a loss of repository integrity. The output from a release scenario analysis will establish the geologic and hydrologic conditions in and around the repository at the time of an identified breach and provide the major geologic boundary conditions for input into the various consequence analysis models.

For the four studies discussed here, release scenarios were developed via modified Delphi methods utilizing expert opinion. Of the four studies, the most complex and thorough release scenario analys is was performed for the Hainesville Study.

\section{INFCE SALT SCENARIO}

The INFCE Salt Study considered both a normal and an abnormal release scenario.

In the normal scenario it is expected that a repository site will not experience a disruptive event within several million years that would release radionuclides to the biosphere at any rate greater than would be expected at the time of emplacement. Solid materials buried in salt generally will not move by themselves. Without flowing water only solid-state diffusion can move the radionuclides from their point of burial. Solid-state diffusion processes, however, are slow and temperature-dependent. We know this intuitively from the fact that ores in vein deposits have not diffused into the surrounding mother rock by measurable amounts in millions to tens of millions of years unless other driving forces were present. Generally a diffusion mechanism is inconsequential at temperatures below one-half of the melting point of the material. 
For perspective on solid state diffusion as a release mechanism, the movement of one waste constituent through a continuous dense rock stratum to an overlying permeable interbed was modeled. (29) The model was designed to use data generally available for an initial evaluation of a deep rock stratum. Based on movement in three dimensions, this model predicts the waste concentration in the dense rock stratum as a function of time. Using results of the full-scale analysis, a simple relationship can be defined for evaluating time for the diffusing constituent to reach the barrier. Specifically, the time required is given by the expression

$$
t^{\prime} m=\frac{0.0145 \ell^{2}}{D}
$$

$t^{\prime} m=$ minimum delay time until a $1 \%$ change in relative concentration reaches the interface between the dense rock stratum and the overlying interbed (unit of time)

$\ell=$ the distance between the source of waste and the edge of the containment barrier (unit of length)

$D=$ diffusion coefficient of the specific waste specie in the particular rock stratum (units of length squared over time).

A conservative estimate (fast movement) of the diffusion coefficient would be $1 \times 10^{-10} \mathrm{~cm}^{2} / \mathrm{sec}$. Estimating the distance between source material and aquifer as $100 \mathrm{~m}$, at least $500 \mathrm{million}$ years would be required for the radionuclides to migrate to the aquifer. If the diffusion coefficient is $1 \times 10^{-13} \mathrm{~cm}^{2} / \mathrm{sec}$, the minimum time will be $5 \times 10^{11}$ years. With the reference repository, the radionuclides would have to diffuse across $350 \mathrm{~m}$ of salt and $190 \mathrm{~m}$ of shale/dolomite/clay before reaching the aquifer. Assuming a diffusion coefficient of $1 \times 10^{-10} \mathrm{~cm}^{2} / \mathrm{sec}$, this would require about $3 \times 10^{9}$ years, or approximately the age of the earth. Because of these extremely long travel times the normal release scenario was not considered in the hydrologic, transport and dose modeling.

In developing the hypothetical abnormal release scenario, an attempt was made to define one that would represent the worst possible release of contaminants while still being reasonable in terms of the release mechanism. The worst case would be one that provides maximum flow through the repository area, 
since this would result in the greatest leaching of the waste and the quickest entry of the waste into the aquifer system. Given the geologic structure as defined in the section "Repository Site Description," a reasonable mechanism allowing for flow through the repository is difficult to envision since the site assumes no aquifer systems below the salt zone. As a result, flow through the repository area must occur by the rerouting of aquifer fluids from above the repository area. If one considers the aquifer fluid to have no salt content and the salt's cap rock to be fractured, then salt dissolution must be modeled along with the associated cyclic solution mining of the salt and subsequent collapse of the overburden materials and resultant change in local permeability.

The question to be answered for this kind of scenario is: How much fluid would be flowing past the salt surface, and how long would it take to dissolve the $350-\mathrm{m}$ salt layer above the repository? This dissolution process can be estimated from an estimate of the maximum rate at which the water could be flowing past the salt's surface. A conservative estimate of that flow rate was made by considering that the salt and cap rock were fractured in a zone through the repository $2400 \mathrm{~m}$ wide to a depth of $450 \mathrm{~m}$ into the salt and of infinite extent parallel to the river. This extremely wide fracture zone was then assigned the same hydraulic properties as the limestone-dolomite-sandstone aquifer. The flow from the aquifer system into this fracture zone over the repository's $1200-\mathrm{m}$ length would be $\sim 9.5 \mathrm{~m}^{3} /$ day. At this maximum rate, assuming the aquifer fluid to originally contain no salt, it would require $\sim 1.35$ million years to dissolve the 1200 by 1200 by $350-m$ overburden of salt before any water reached the repository.

Actualiy dissolution of the salt as a result of shaft failure, or some more reasonable fracture of faulting of the salt cap rock, would be much slower because the initial flow rate of fresh water past the salt would be much lower than this maximum rate; moreover, the flow rate from the fractured cap rock or failed shaft seal would be greatly retarded by the large density gradient between the fresh water in the limestone-sandstone-dolomite aquifer and concentrated brine in the shaft or fractured cap rock. The resultant movement of 
brine from the shaft or fractured cap rock would be more realistically determined by characteristically slow molecular diffusion or by second- and thirdorder flow effects arising from fresh water flowing past a hole or fracture filled with a dense brine.

Because of these considerations, the salt dissolution scenario was discarded and the fracture scenario described above for estimating worst case flow was chosen as representative of the worst case. For the fracture scenario it was assumed that the fluid in the limestone-dolomite-sandstone aquifer was a concentrated brine so that effects of retardation due to density gradients could be neglected. The somewhat unrealistically wide fracture zone can be thought of as resulting from a multiple fracture pattern through the repository area or from the collapse of an undetected solution pocket beneath the repository. This worst case fracture scenario allows the aquifer fluid to contact al1 the repository waste from the onset of the fracture process and allows the effects of maximum flow through the repository from the onset of the fracture to be addressed.

Only this one abnormal scenario was modeled. The design of reasonable scenarios that would expose the waste to aquifer fluids is extremely challenging because of their improbability. It should also be pointed out that any scenario modeled needs to be weighted according to its probability of occurrence.

\section{PARADOX BASIN SCENARIO}

In the Paradox Basin Study the release scenario was developed from considering a possible but very improbable event. A seismic event was assumed to generate a fault system through the repository with an alignment parallel to the disposal rooms in such a way that one entire room of spent fuel (1000 MTHM) was exposed. The fault fracture system was assumed to extend from the base of the lower aquifer through the bedded salt formation to the top of the upper aquifer. The length of the fault was taken to be 10 miles (about the same as some faults mapped in the area), and the width of the fracture zone to be about $5 \mathrm{ft}$. Permeability of the fault zone was assumed to be $500 \mathrm{ft} / \mathrm{yr}$, or about 
ten times the permeability of the lower aquifer. A simple analytical model was used to calculate a vertical flow of $19.5 \mathrm{gpm}$ of water through the fracture zone.

\section{HAINESV ILLE SALT DOME SCENARIO}

The development of release scenarios for the Hainesville Study was based on a team of AEGIS and consultant personnel's addressing three categories of release scenarios:

- 1--resulting from a natural, continuous sequence of geologic processes ultimately disrupting the repository

- 2--resulting from catastrophic impact of a discrete event such as meteorite impact

- 3--resulting from human-induced phenomena.

For consideration of Types 1 and 2, the team systematically investigated geologic phenomena that could potentially disrupt a repository. For Type 3 scenarios the team comprehensively assessed ways man might deliberately or inadvertent ly cause a future interaction between remaining radioactive materials and the human environment.

The systematic consideration of Types 1 and 2 release phenomena indicated that no plausible natural mechanism would cause a breach of the repository within the million years mandated for AEGIS consideration. Therefore, no natural geologic breach scenario was considered in this study.

The probability for and the consequences of deliterate or inadvertent human intrusion, in terms of radionuclides released, was determined to potentially far outweigh the consequences and probability of release through gradual ground-water contamination from natural mechanisms. As a result, a Type 3 human intrusion scenario was selected for the Hainesville Study.

The specific human-intrusion scenario involves the solution mining of the salt dome to produce salt. The time of initial intrusion was assumed to be the 
earliest possible time following the loss of institutional control, at 100 years. However, to illustrate the effect of that timing on the consequences, an identical scenario was analyzed, starting at 1000 years after closure. The solution mine was assumed to remain operational until it breached the side of the salt dome. At that time solution mining ceased and flux through the breached dome continued as a result of leakage from the abandoned solution mining wells.

In this scenario there are two pathways to the biosphere for contaminated water: 1) by leaching of radionuclides into the brine being extracted during the operational phase of the mine and 2) by subsequent leaching into the local aquifer and geotransport to the aquifer discharge sites as a result of abandonment of the breached solution mine. Pathway 1 is generic to salt domes, whereas pathway 2, the chronic-type pathway, must be analyzed in any siterelated assessment. The chronic pathway has essentially three phases in its full development: 1) leaching into the aquifer system based on an intact conduit as input continues from the surface water system through the abandoned solution mine shaft, 2) leaching into the aquifer system after partial collapse of the geosystem above the cavity due to collapse of the solution mine, and 3) leaching into the aquifer after total dissolution of the salt dome overlying the repository and the concomitant collapse of the overlying strata. For the purposes of this consequence analysis, this three-phase scenario was simplified into two phases by assuming that the initial collapse of the solution mine cavity does not occur until the salt dome above the repository dissolves completely away.

\section{INFCE GRANITE SCENARIO}

Uplift, faulting, and fracturing, and the rate at which they occur in igneous and metamorphic rocks are the most significant effects of tectonic activity of concern to the development of a release scenario for granite. The distribution of mobile zones and stable areas is generally well known on the basis of earthquake statistics and structural evidence. Normally there is agreement regarding the age of fractures and the time of the most recent activity in areas generally considered stable. There is a general consensus 
that post-glacial displacements have occurred chiefly along pre-existing fractures. The evidence generally indicates that a repository in granite could be sited away from major pre-existing fracture zones and, therefore, would not be endangered by future seismic activity.

Events such as shear displacements along existing fracture planes might result in changes in rock mass permeability. No data yet exist indicating that this would necessarily have any detrimental effect at the repository leve1. The main impact on the hydrologic system resulting from tectonic and erosional activity would be to change local gradients and the location of recharge and discharge areas. Usually the areal exposure of Precambrian granites and gneisses, which originally formed at great depth, in itseif indicates that erosion has reached a mature stage in removing the overlying formations. Therefore the potential is very small for renewed erosion, particularly in flat and low-lying areas outside recent orogenic regions and away from major rivers.

For the reasons stated above, no specific violent or abnormal scenario causing release of radionuclides from the hard rock repository was considered. The most realistic and probable release mechanism results from the normal, slow water movement of the in situ rock waters through the very low permeability rock. It was assumed that the relatively inexpensive stainless steel canisters and drums, in which the waste was stored, would simultaneousiy fail after 100 years. This fixes the elapsed time before the release begins. 


\section{HYDROLOGIC MODELING}

Prediction of the transport of radioactive contaminants requires estimating the water movement because water would be the primary carrier of waste in hydrogeologic systems. Hydrologic models define water-flow paths, quantity, and travel times from input data describing the hydrologic system and the release scenario chosen.

The type of code applied to a particular study area depends on: 1) the physical nature of the study area; 2) the availability and quality of geohydrologic data; and 3 ) the desired model output. Two different ground-water codes were used in modeling the four studies discussed here. The Paradox Basin was modeled with the Variable Thickness Transient (VTT) Code; ${ }^{(30)}$ the INFCE Salt and Hard Rock Studies used the Finite Element Three-Dimensional Ground-Water (FE3DGW) Code; ${ }^{(31)}$ and the Hainesville Study used both codes. The FE3DGW code was used for the near-dome modeling and the VTT code for the regional modeling.

$V T T$ is a two-dimensional, finite-difference numerical code that solves the partial differential equation describing unconfined, saturated transient flow through porous media. The capability also exists to run steady-state simulations and to run the model for confined aquifer systems if desired. In addition, VTT can be used to simulate multilayered two-dimensional aquifers connected through interaquifer transfer. Specifically, a horizontal $X-Y$ coordinate grid system is adapted to represent a study area. Model parameters defining the aquifer system are assigned to, and evaluated at, nodes in the center of each grid block and are considered representative of the whole grid block area. With the values obtained from the nodes, the code calculates the ground-water surface elevation at each node. It also calculates ground-water flow paths, flow quantities, and travel times.

The FE3DGW code is a three-dimensional, finite element numerical code that solves the equations describing fully three-dimensional, saturated ground-water flow. The code can simulate confined and/or unconfined, multilayered systems and can be run in either a steady-state or transient mode. Because the code uses the finite-element method (irregular grid), it is a more powerful tool for 
representing irregular boundaries (lakes, rivers, outcrops, etc.) than is the finite-difference method (using uniform square or rectangular grids).

The FE3DGW code divides a region into a number of discrete nodes and elements at which all hydrologic parameters are defined. Connecting the nodes results in subdividing the entire surface region into two-dimensional elements. Spacing of the model nodes can be varied as required, thereby allowing a closer spacing and smaller elements (i.e., higher resolution in the results) in areas of interest (i.e., around the repository) and a larger spacing in areas where limited data or less complex interactions are present.

Some of the complex generic and site-specific geologic configurations consist of multiaquifer systems, and these aquifers respond conjunctively to stress imposed on any of the various layers. The finite element model can simulate these multilayered systems, where not only thickness can vary but the number of layers can be changed to agree with the vertical geologic section. Moreover, the hydraulic conductivity and the pumping stresses can change from layer to layer and/or from element to element, thereby allowing an accurate representation of confining layers' heterogeneities and interaquifer transfer.

To provide for interaction with geologists, engineers, and decision makers, supporting programs have been developed for both the VTT and FE3DGW codes to plot background maps, grid values, contour maps, streamlines, and various three-dimensional graphics. These programs can be used to interpret and check the accuracy of input data as well as output predictions and to perform various kinds of analysis of these predictions.

\section{INFCE SALT HYDROLOGIC MODEL}

In order to best represent the multilayered hydrogeologic system of the bedded salt, the FE3DGW code was used. The first stage of the modeling effort involved examining the geohydrologic data and developing a conceptual model of the system. Much of this information was extracted from the appendix to CC WG.7/38, (14) but additions and adjustments were made as required to properly define the system for use in the modeling effort. 
The modeled area consists of a hypothetical waste repository, a un iform flow region from the repository to the biosphere uptake point, and uniform layering of five distinct geohydrologic units. Data supplied on the aquifer systems addressed only the change in properties with depth; this necessitated modeling the system as an $X-Z$ system, with properties being uniform along the $Y$ dimension. Since the three-dimensional code was used, this $X-Z$ system had to be modeled with one row of three-dimensional elements in the $X$ direction. As a result, the surface of the region was simulated by a row of 20 rectangular linear elements involving 46 surface nodes (Figure 21). The elements are $1200 \mathrm{~m}$ wide in the $Y$ dimension (approximate length of one repository storage room) and $500 \mathrm{~m}$ long in the $x$ dimension. In the area of the salt layer and the river the node spacing was changed to 300 and $100 \mathrm{~m}$, respectively, to more accurately represent the actual size of the repository and a typical river. The total horizontal length of the region is $8600 \mathrm{~m}$, and the distance from the repository to the river is $5000 \mathrm{~m}$. The width over the entire region is $1200 \mathrm{~m}$.

For modeling, the vertical dimension consists of four uniform geohydrologic units extending the length of the model region plus a fifth layer of salt that exists only in the area of the hypothetical repository. Table 9 outlines a geologic description of the layers and their applicable hydrogeologic parameters. In the model, vertical nodes were placed at the intersection of the layers (Figure 22). Additional nodes were evenly spaced in the thicker layers (i.e., layers 3, 4, and 5 in Figure 22) to increase resolution and accuracy in the model results. The combined thickness of all vertical layers is $700 \mathrm{~m}$.

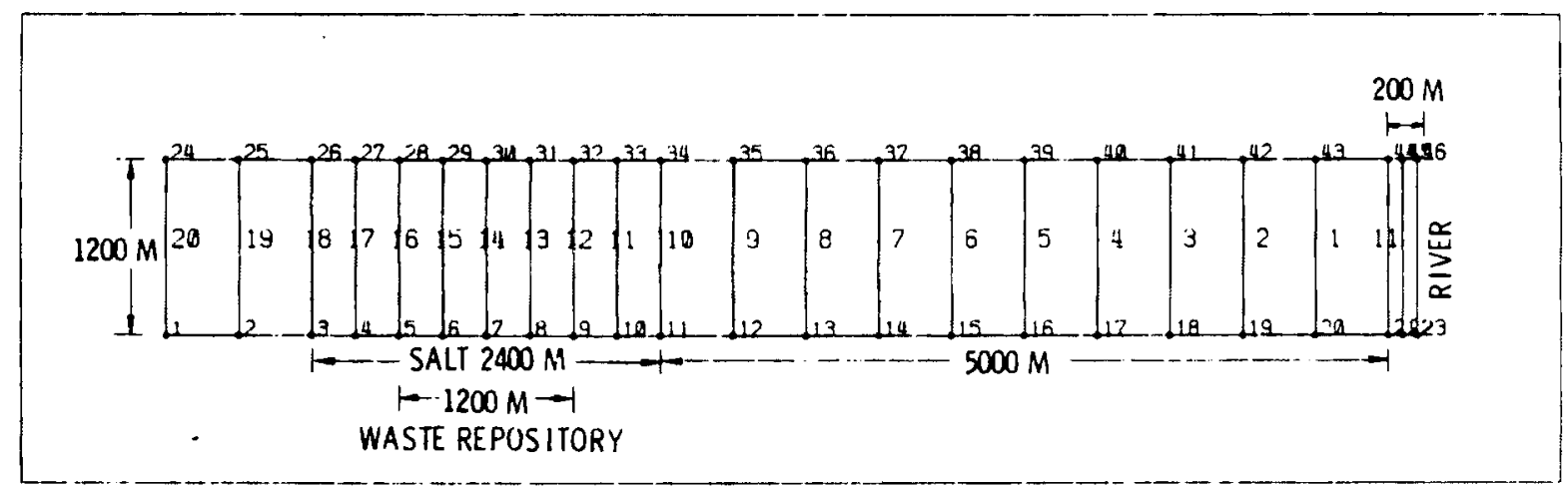

FIGURE 21. Plan View of INFCE Salt Study Model Region 
TABLE 9. INFCE Salt Study Finite Element Model

Hydrogeologic Input Parameters

\begin{tabular}{|c|c|c|c|c|}
\hline Layer & Rock Type & $\begin{array}{c}\text { Thickness, } \\
\mathrm{m} \\
\end{array}$ & $\begin{array}{l}\text { Hydraulic Conduc- } \\
\text { tivity, m/day } \\
\end{array}$ & $\begin{array}{c}\text { Porosity, } \\
\%\end{array}$ \\
\hline 1 & $\begin{array}{l}\text { Unconsolidated sand, } \\
\text { gravel and silt }\end{array}$ & 10 & 5.9 & 20 \\
\hline 2 & $\begin{array}{l}\text { Calcareous shale, } \\
\text { partiy sandy }\end{array}$ & 30 & 0.01 & 13 \\
\hline 3 & $\begin{array}{l}\text { Sandstone, dolomite, } \\
\text { cherty limestone }\end{array}$ & 160 & 0.06 & 20 \\
\hline 4 & $\begin{array}{l}\text { Interbedded shale } \\
\text { and dolomite (salt } \\
\text { cap rock) }\end{array}$ & 50 & 0.006 & 20 \\
\hline $4 a$ & $\begin{array}{l}\text { Fractured, interbedded } \\
\text { shale and dolomite } \\
\text { (salt cap rock) }\end{array}$ & 60 & 0.06 & 20 \\
\hline 5 & Salt & Infinite & 0.00006 & 0.5 \\
\hline $5 a$ & Fractured salt & 450 & 0.06 & 20 \\
\hline
\end{tabular}

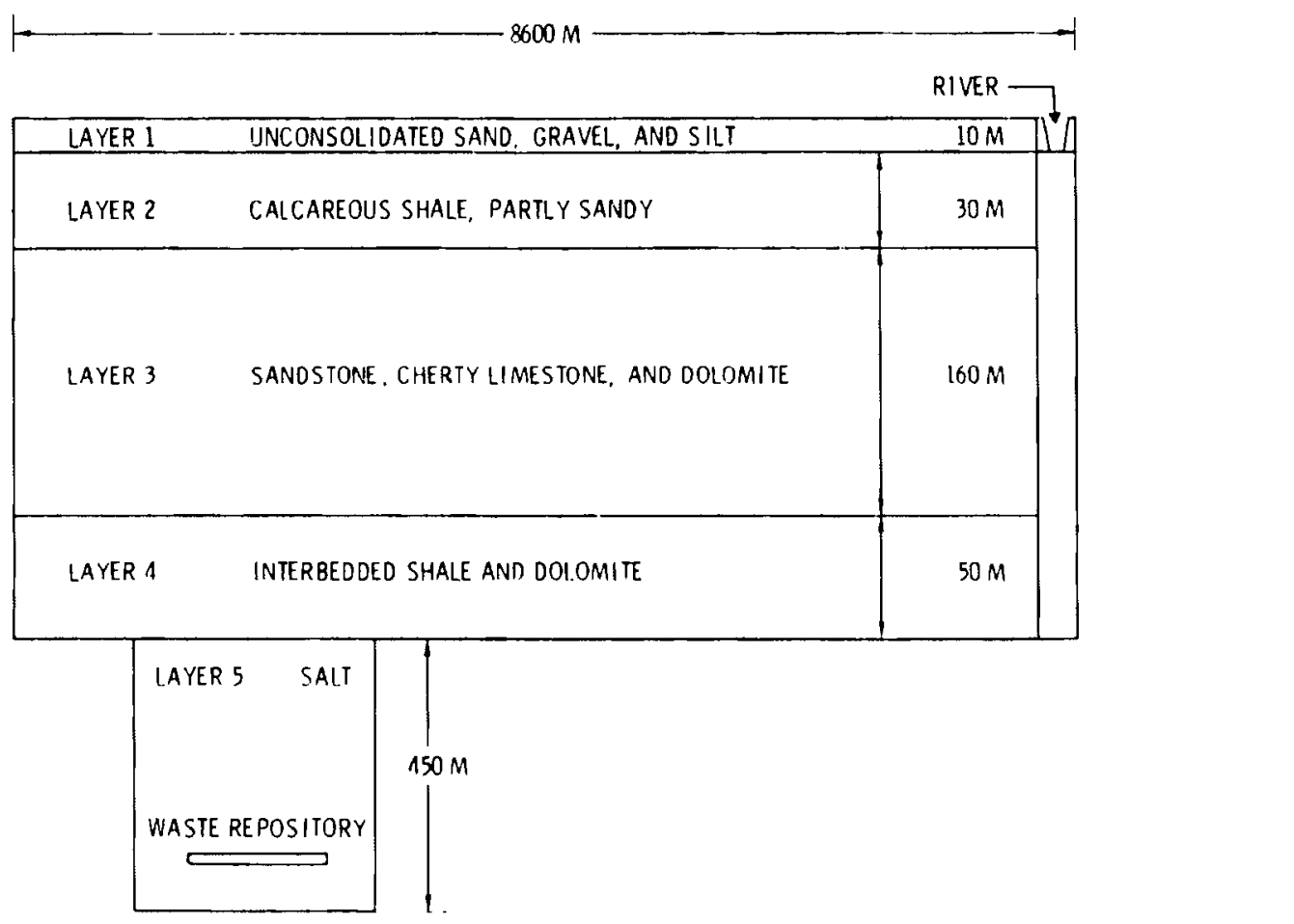

FIGURE 22. Cross Section of the Five Geologic Layers Used To Define INFCE Salt Study Model Region 
The hypothetical repository was assumed to be a $1200-m$ square. This area closely approximates the 50 to 60 ha required for any of the INFCE reactor strategies. The repository was placed $600 \mathrm{~m}$ below the surface and centered in the area of the fractured salt formation.

The regional water table was assumed to have a uniform gradient of $1 \mathrm{~m}$ in $1 \mathrm{~km}$, and the river elevation to be $190 \mathrm{~m}$ above sea level. The repository is up-gradient from the river, and the water table elevation at the repository is about $195 \mathrm{~m}$ above sea level. To keep this gradient, a flux was calculated for each of the top four layers and was input in the model at the most upstream nodes.

The river was assumed to be the regional discharge site for all the waterbearing layers. To simulate this in the model, the river was made to intersect the upper layer at nodes 23, 1023, 46, and 1046, and all nodes below this were considered no-flow boundaries (Figure 23 ). This would force the water in the lower layers to move up to the river as shown in Figure 13.

The output from the hydrologic model is the ground-water potential (elevation) distribution throughout the $X-Z$ plane over the $X-Z$ region modeled. $A$ contour plot of these potentials with super imposed water flow paths is shown in the $X-Z$ cross-section $p l$ ot of Figure 24 . As a result of fracturing the salt formation and the overlying shale in the area of the repository, some of the water is able to flow down through the repository and eventually reach the river.

An auxiliary program for the finite element model can calculate travel time, travel distance, and velocity of the water along any streamline within the region. These values are calculated according to the hydraulic conductivities, porosities, and gradients of the various layers along the flow path. The input required by the transport model is an average for the flow tube encompassing the $600 \mathrm{~m}$ on the down-gradient side of the repository (see Figure 24). The averages were calculated using a weighted average according to flow for multiple flow tubes and streamlines spaced along the repository. The values used in the transport model are the following averages: 


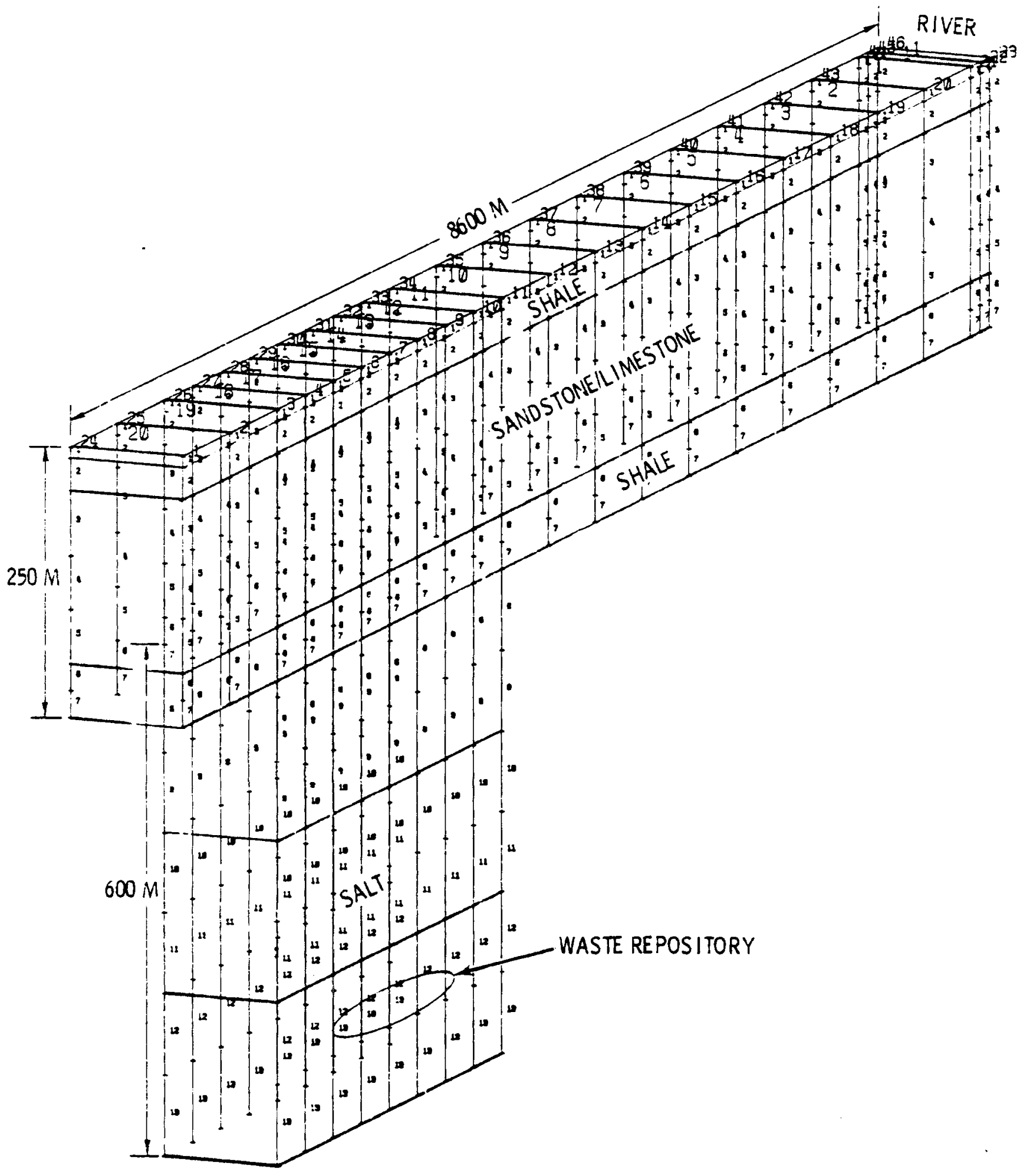

FIGURE 23. Three-Dimensional View of INFCE Salt Model Region 


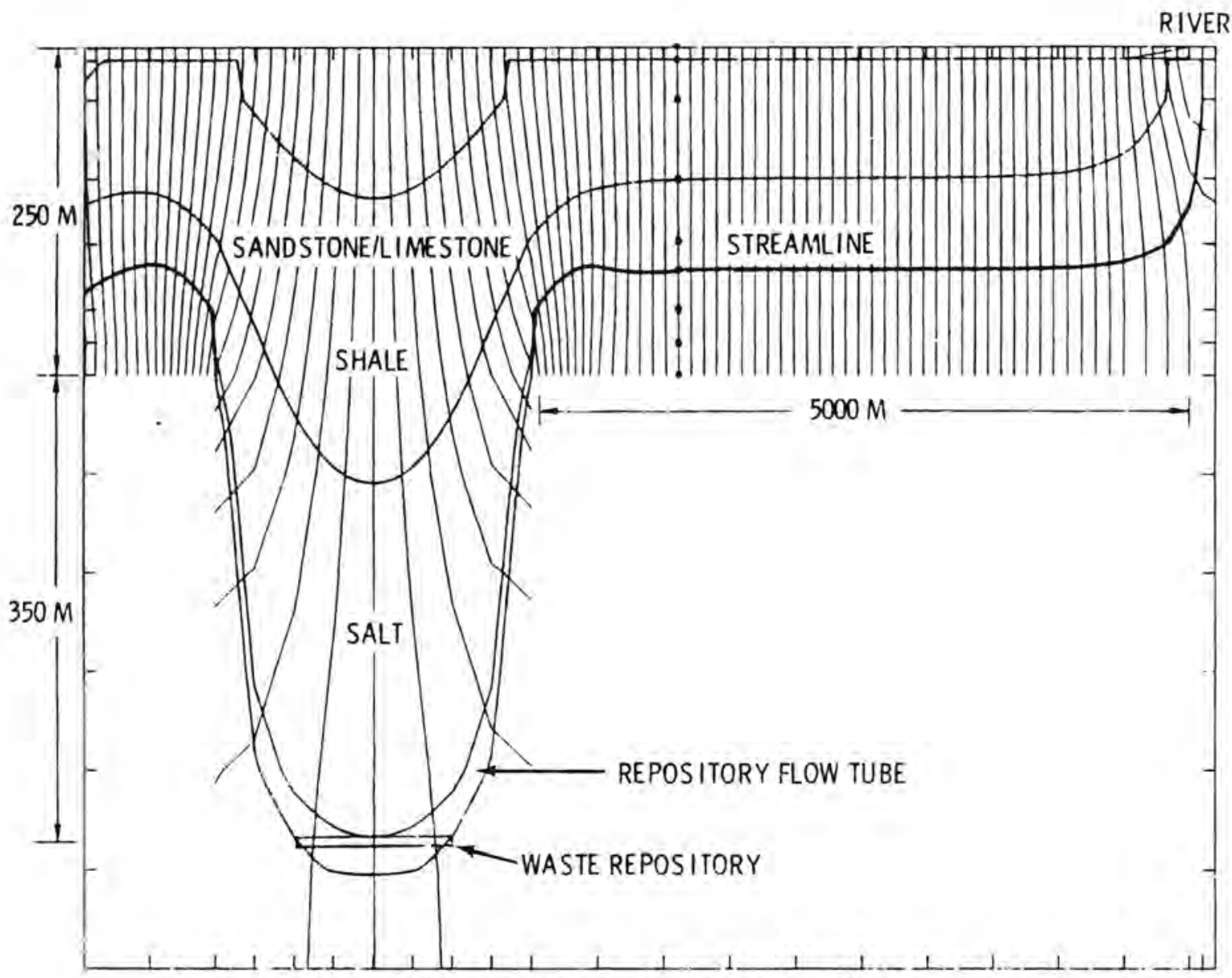

CAOSS SECTION OF INFCE NUCLEAR WASTE REPOSITOAY MODEL REGION

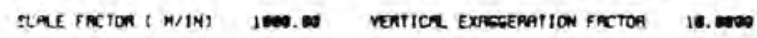

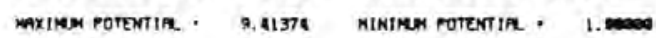

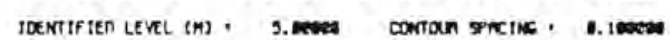

FIGURE 24. Contour Plot of Model-Predicted Vertical Ground-Water Potentials with Superimposed Streamiines (INFCE Salt Study)

- distance - $6100 \mathrm{~m}$

- travel time - 100,000 yr

- velocity - $0.06 \mathrm{~m} / \mathrm{yr}$

- width of the flow tube $-60 \mathrm{~m}$

- flow through the flow tube $-190 \mathrm{~m}^{3} / \mathrm{yr}$. 
PARADOX BASIN HYDROLOGIC MODEL

The Paradox Basin in the region of interest can be represented by a twoaquifer system. The lower aquifer with the higher potential consists of the Mississippian aquifer (Leadville limestone). This lower aquifer system in the region of interest is separated from the upper aquifer system by the impermeable Paradox Formation. The upper aquifer system consists of the Honaker Trail and Permian Formations (Cutler-Rico) combined, acting essentially as a single aquifer. The generalized potentials for these systems are shown in Figure 25. The formations that comprise the upper aquifer system outcrop along the Colorado River as shown in Figure 25, and the potentiometric map indicates that the Colorado River acts as a discharge site for these aquifers. The Green River lies above the upper aquifer system except near the confluence of the two rivers. Figure 25 also locates two geologic sections, Section $A-A^{\prime}$ and Section $B-B^{\prime}$.

Figure 26 shows the generalized geologic section along $A-A^{\prime}$. The stratigraphic units have been grouped into a lower aquifer (Leadville limestone), central bedded salt and shale zone (Molas, Pinkerton Trail and Paradox Formations), an upper aquifer (Honaker Trail, Rico and Cutler Formations), and an upper aquitard (Moenkopi Formation and above). Section A-A' parallels the length of the hypothetical repository and runs approximately perpendicular to the hydraulic gradients in both the upper and lower aquifer. Figure 27 shows the generalized geologic section along $B^{-} B^{\prime}$. The section runs approximately parallel to the hydraulic gradient.

For modeling purposes, a composite potentiometric map was prepared for the upper aquifer in the region of interest. Based on this potentiometric map and the other details about the formation, the boundary conditions for the upper aquifer system were chosen. Figure 28 shows the model boundaries and composite potential surface for the upper aquifer system. Thickness of the upper aquifer unit was determined from a cross-section prepared from a surface geologic map. The unit was modeled as a uniform layer $1000 \mathrm{ft}$ thick with the maximum observed permeability values of $100 \mathrm{ft} / \mathrm{yr}$. 
o

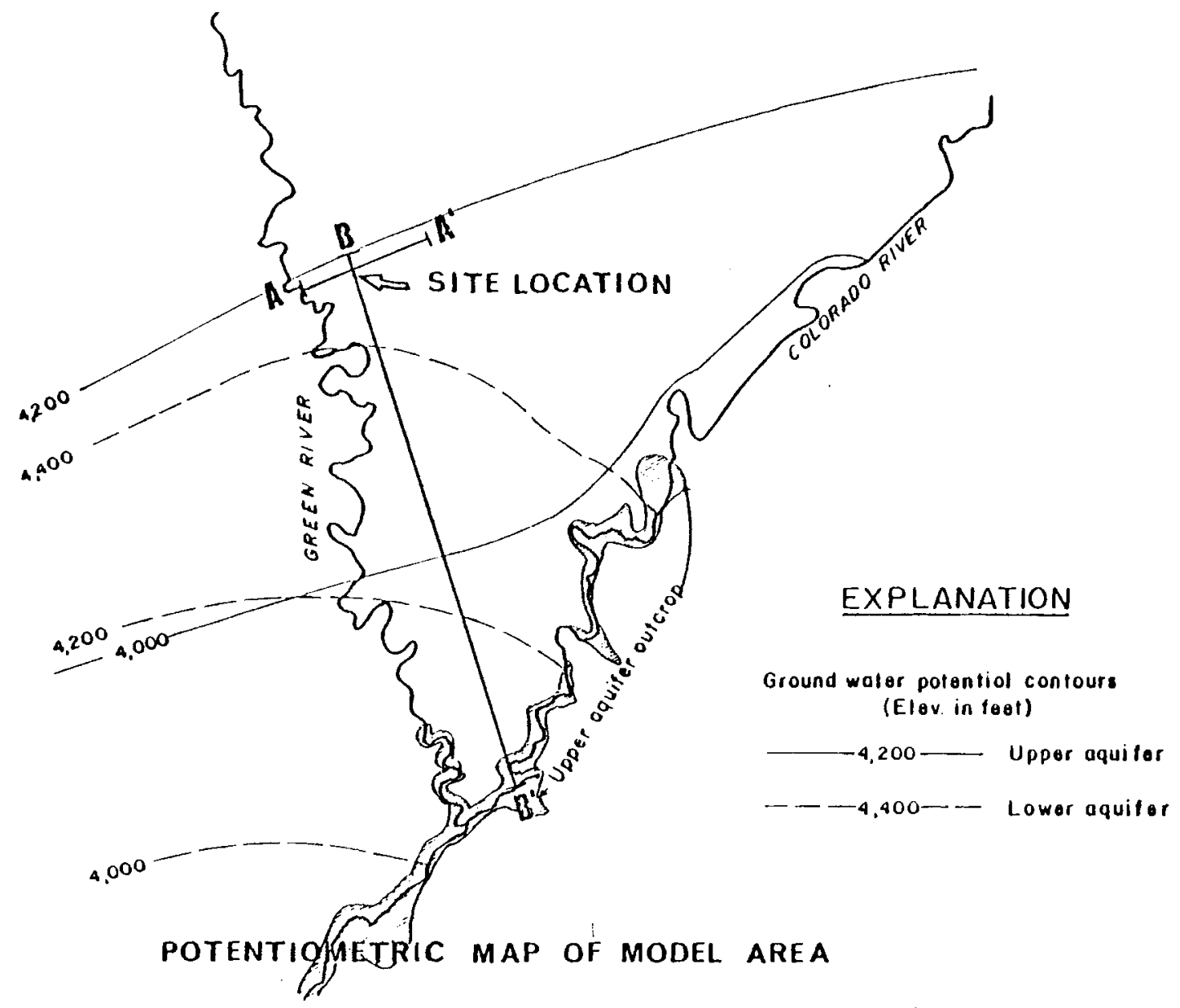

FIGURE 25. Potentiometric Map of Paradox Basin Model Area 


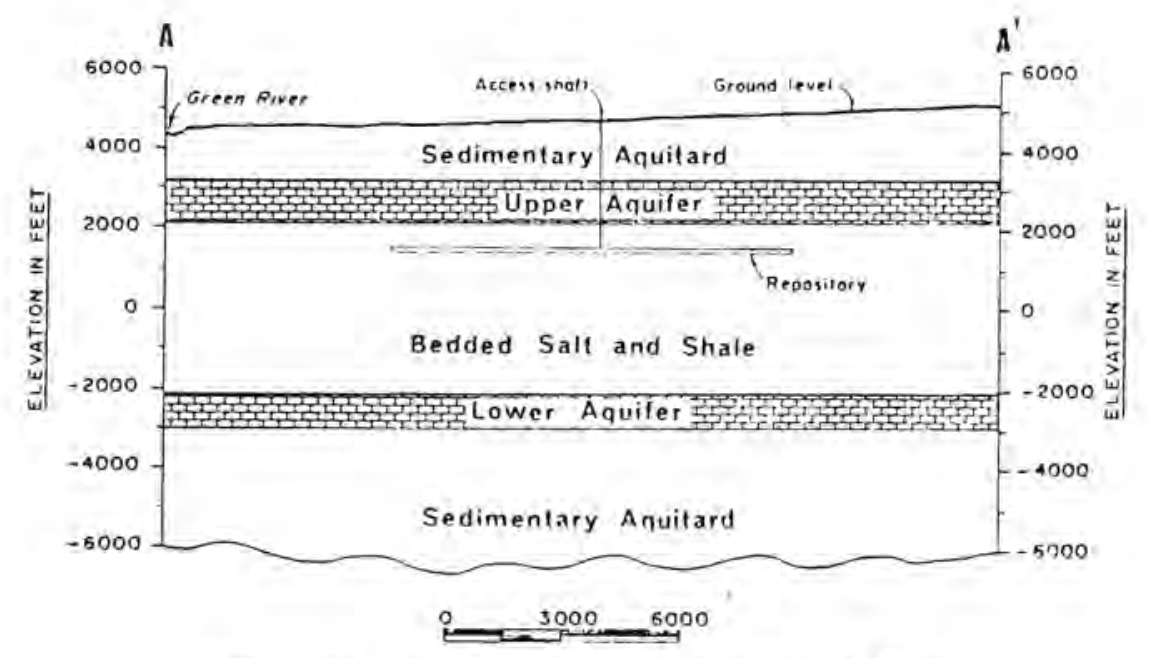

Vertical and Horizontal Scale in Feet

FIGURE 26. Section Perpendicular to Hydraulic Gradient in Paradox Basin

Parameters on the lower aquifer were compiled for calculating the leakage rate between the two-aquifer system through the fault zone considered for the release scenario. The thickness of the lower aquifer unit was taken as $500 \mathrm{ft}$ and the permeability as $45 \mathrm{ft} / \mathrm{yr}$, the average of available drill stem tests. The potential in the lower aquifer unit was determined to be $250 \mathrm{ft}$ greater than the potential in the upper unit.

The bedded salt formation separating the two aquifers is $4500 \mathrm{ft}$ thick in this region. The aquifer fluids in the lower and upper systems are essentially saturated brines, and their potentials were corrected to fresh water for use in this study.

Based on the conceptual model formulated from the available data, the VTT model was chosen to simulate the upper aquifer. The model was used to determine the water path and travel time from the repository to the discharge site (Colorado River). From the hydrologic model-calculated potential distribution throughout the area simulated, the rate and direction of water movement in the aquifer were determined. This velocity field provides one component of the data required to run the transport code. The potential surface was analyzed by one of the VT auxiliary programs to determine the starting locations for 


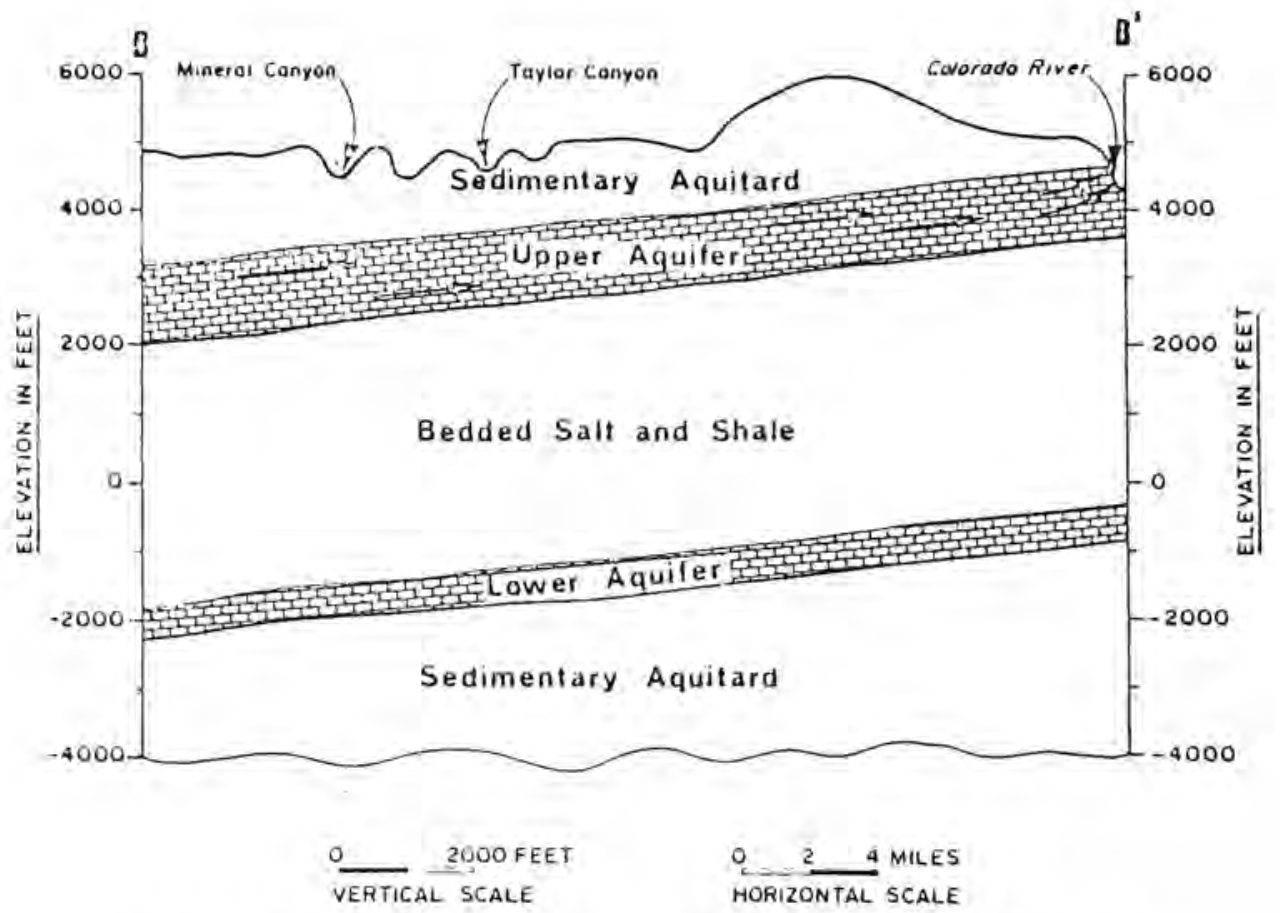

FIGURE 27. Section Parallel to Hydraulic Gradient in Paradox Basin

five flow tubes equal in flow that start at the juncture of the fault, which runs vertically and horizontally through the repository and connects the lower aquifer unit with the upper aquifer.

The five flow tubes defined by the six streamlines are shown in Figure 29. Each carries about $7.3 \mathrm{gpm}$. The average flow tube length, water velocity, and water travel times are shown in Table 10.

\section{HAINESVILLE HYDROLOGIC MODEL}

The Hainesville Study illustrates a case where the hydrologic codes had to be used for both a near-field and far-field assessment of the abandonment pathway of the solution mining scenario. The actual operational pathway of the solution mining scenario did not require use of the hydrologic or transport models and will be discussed in the dose modeling section of this report. The chronic release associated with the abandonment pathway, however, required use of two near-field hydrologic models; this permitted the conservative estimate of the rate of ground-water flow past the waste in the breached, abandoned 


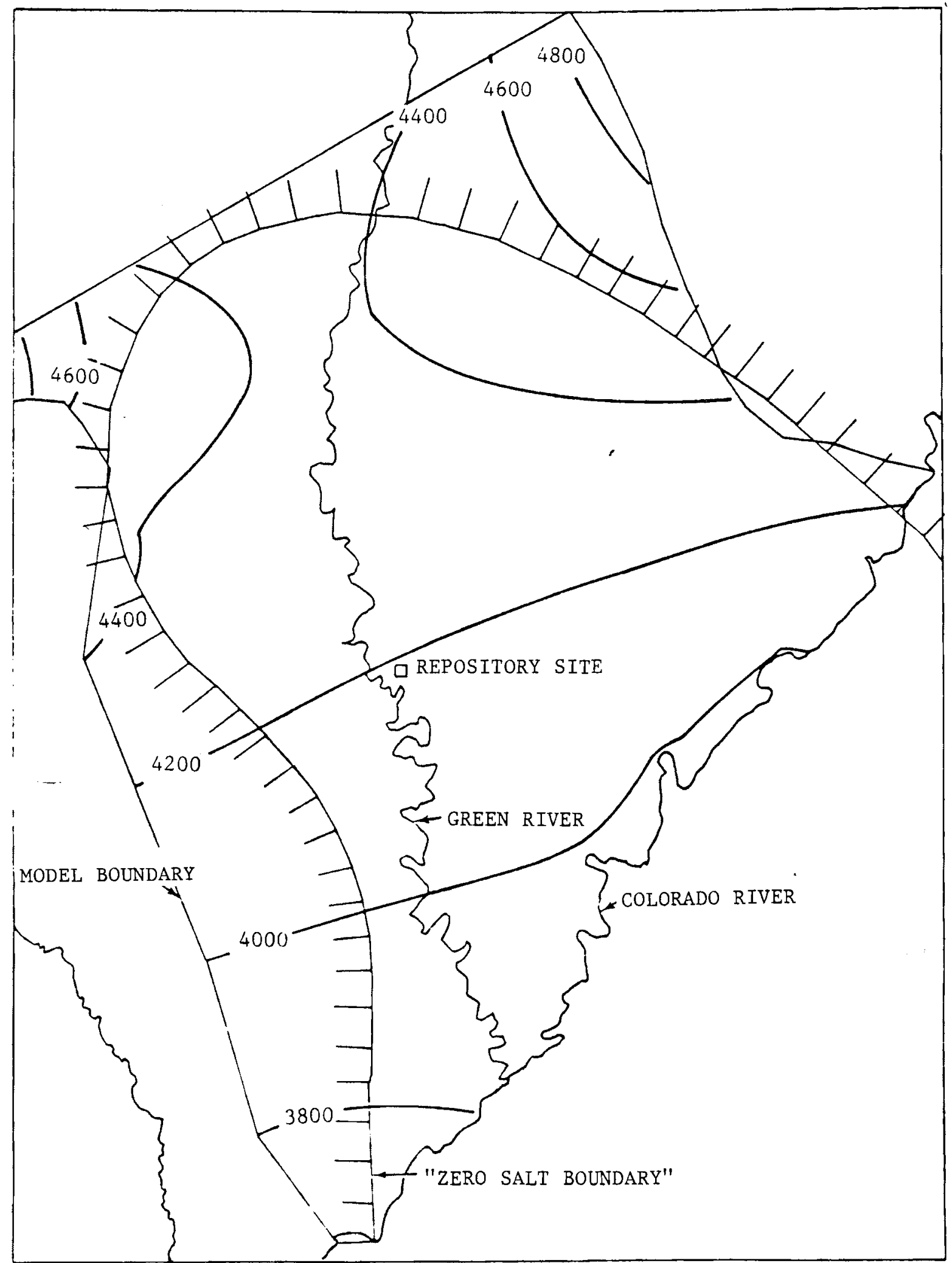

FIGURE 28. Modeled Region with Boundary Conditions and Composition Potentials for the Paradox Basin (units are in feet) 


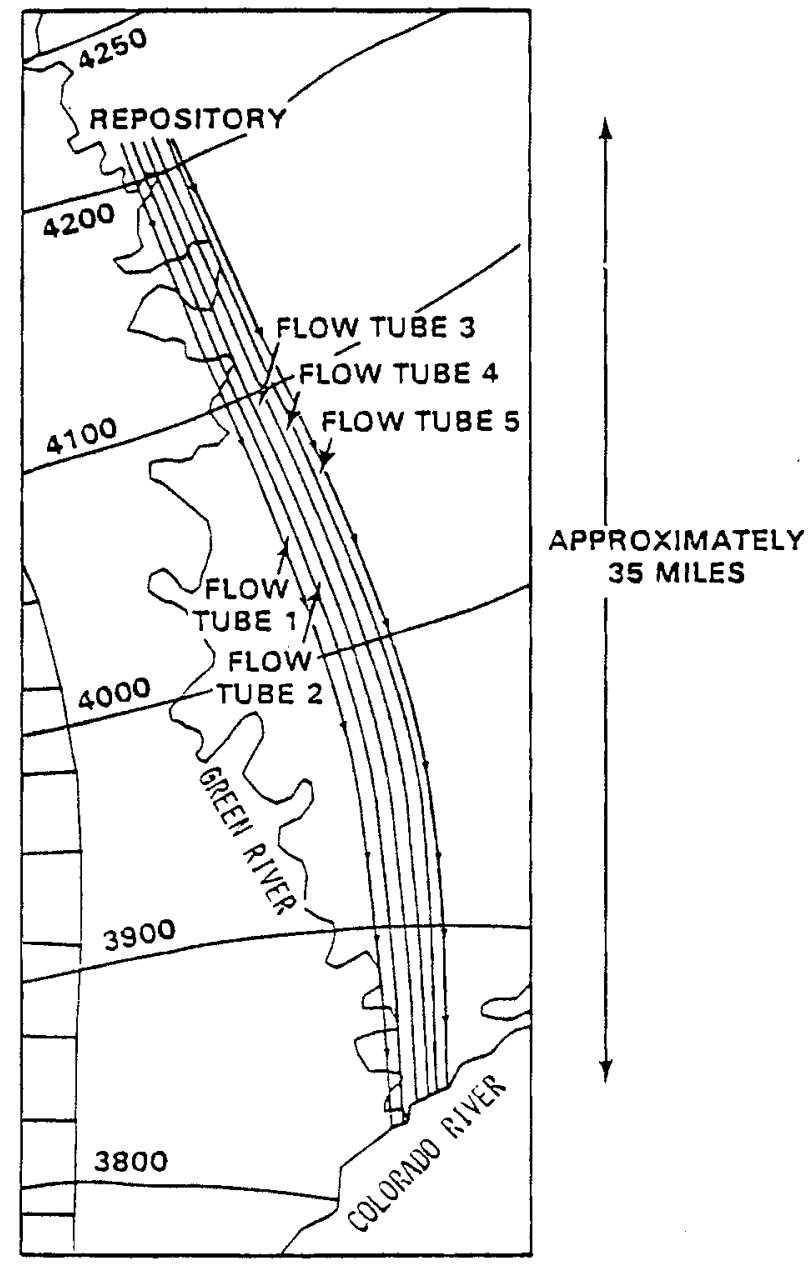

FIGURE 29. Ground-Water Flow Tubes and Streamlines from Breached Repository to the Colorada River for the Paradox Basin Study

TABLE 10. Paradox Basin Hydrologic Model Results

$\begin{array}{ccccc}\text { Flow Tube } & \begin{array}{c}\text { Average Travel } \\ \text { Time, yr }\end{array} & \begin{array}{c}\text { Velocity, } \\ \text { ft/yr }\end{array} & \begin{array}{c}\text { Average } \\ \text { Length, ft }\end{array} \\ 2 & 43,700 & & 4.26 & 186,188 \\ 3 & 43,500 & & 4.24 & 184,500 \\ 4 & 43,200 & 4.22 & 182,250 \\ 5 & 43,000 & 4.19 & 180,563 \\ & 43,000 & 4.16 & 179,438\end{array}$


solution mine before and after the eventual collapse of the mine and overburden caused by continued dissolutioning following abandonment. The FE3DGW model was used for two near-dome hydrologic simulations and the VTT model for the regional simulations used to supply input to the transport model. For the two near-dome simulations that have point source/intensive subregional recharge and vertical variation in thickness and hydraulic properties, the FE3DGW model can represent the problem effectively by varying the node spacing both horizontally and vertically and by accounting for the vertical and horizontal flow patterns around the breached dome.

Figure 30 depicts the hydrogeology of the subregion surrounding the salt dome before eventual collapse of the solution cavity. This was modeled with FE3DGW to determine the flow rate past the waste as a result of the solution mine abandonment. The top aquifer (Carrizo) is $100 \mathrm{ft}$ thick and has a hydraulic conductivity of $13.2 \mathrm{ft} /$ day. The main aquifer surrounding the repository (Wilcox) is $2000 \mathrm{ft}$ thick and has a hydraulic conductivity of $2.5 \mathrm{ft} / \mathrm{day}$. The top of the salt dome and the repository are $900 \mathrm{ft}$ and $1700 \mathrm{ft}$ below the surface, respectively. The Sparta-Queen City Aquifer above the Carrizo was not modeled but it was accounted for in that it provides a 50-ft driving head for moving water through the breached, abandoned solution mine.

The rate of water flow past the waste and into the ground-water system was estimated with the FE3DGW code by assuming an intact, abandoned solution mining casing to connect the Sparta-Queen City aquifer (50 ft higher in head) to the wilcox Aquifer through the solution mine via the the $1000-\mathrm{ft}^{2}$ breach in the side of the dome. The Wilcox-Carrizo subregion was represented by a 500-ft grid and the dome by radially oriented elements (Figure 31). Only half of the subregion was actually modeled because the other half is the mirror image. The model used only three vertical nodes to represent the Carrizo and Wilcox aquifers throughout most of the modeled area. In the area with radial elements, however, five vertical nodes were used to increase the resolution of vertical movement. At the dome breach a $500-\mathrm{ft}^{2}$ element (half of the total breach) was established. Figure 32 shows the stratification near the salt dome, illustrating the variable grid used to simulate the salt dome and the breach. 


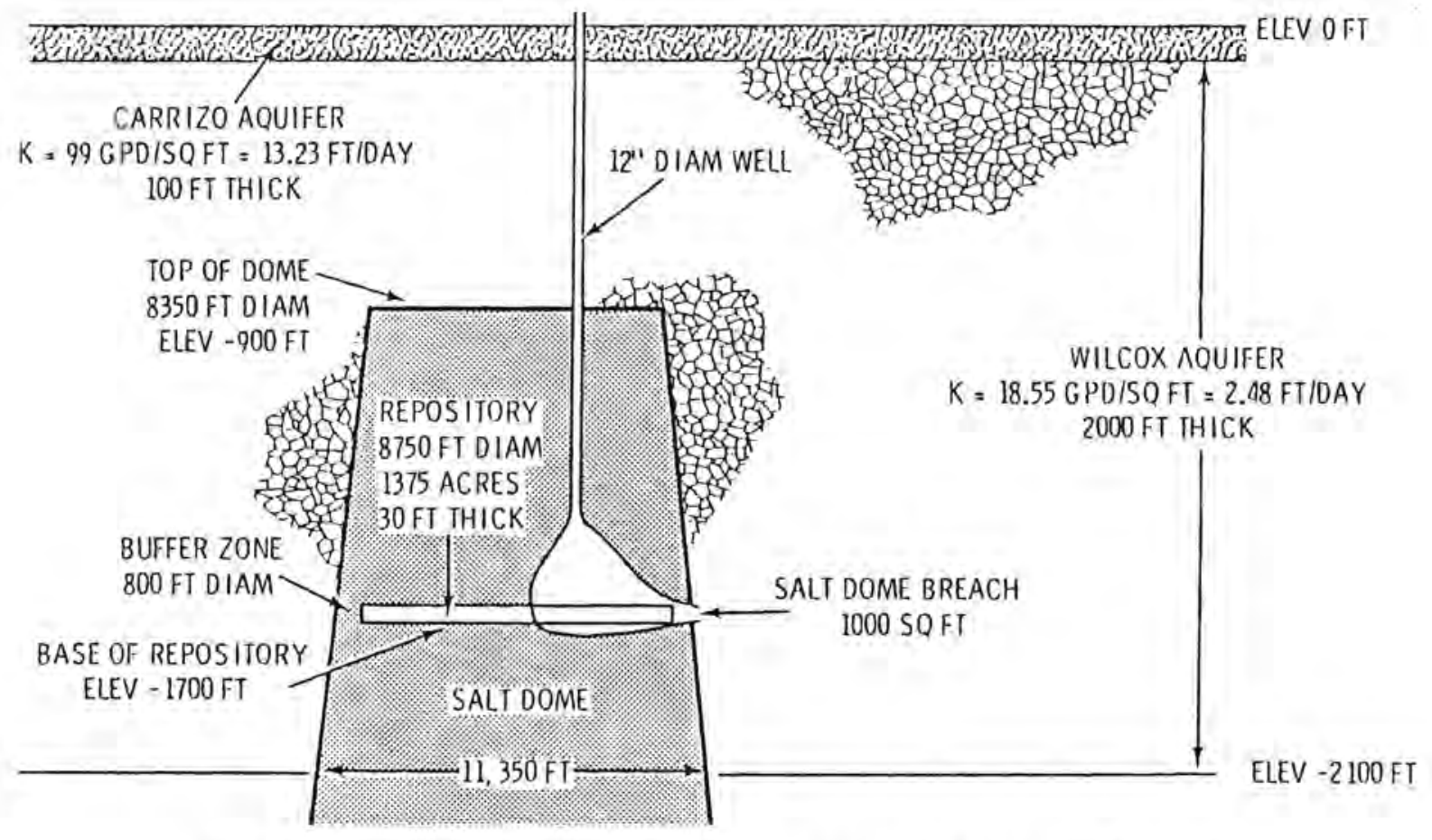

FIGURE 30. Schematic Representation of Hainesville Salt Dome Hydrogeology Before Eventual Collapse of the Abandoned SoTution Mine

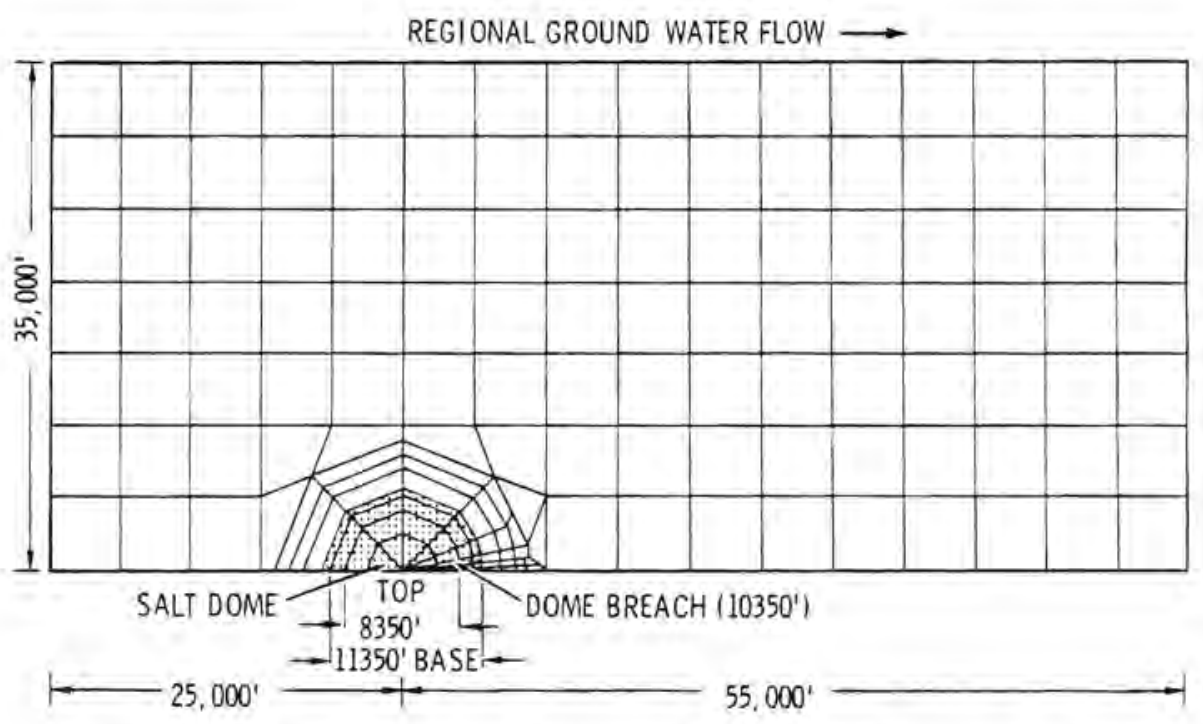

FIGURE 31. Finite Element Grid with Closer Node Spacing near Hainesville Dome Breach 


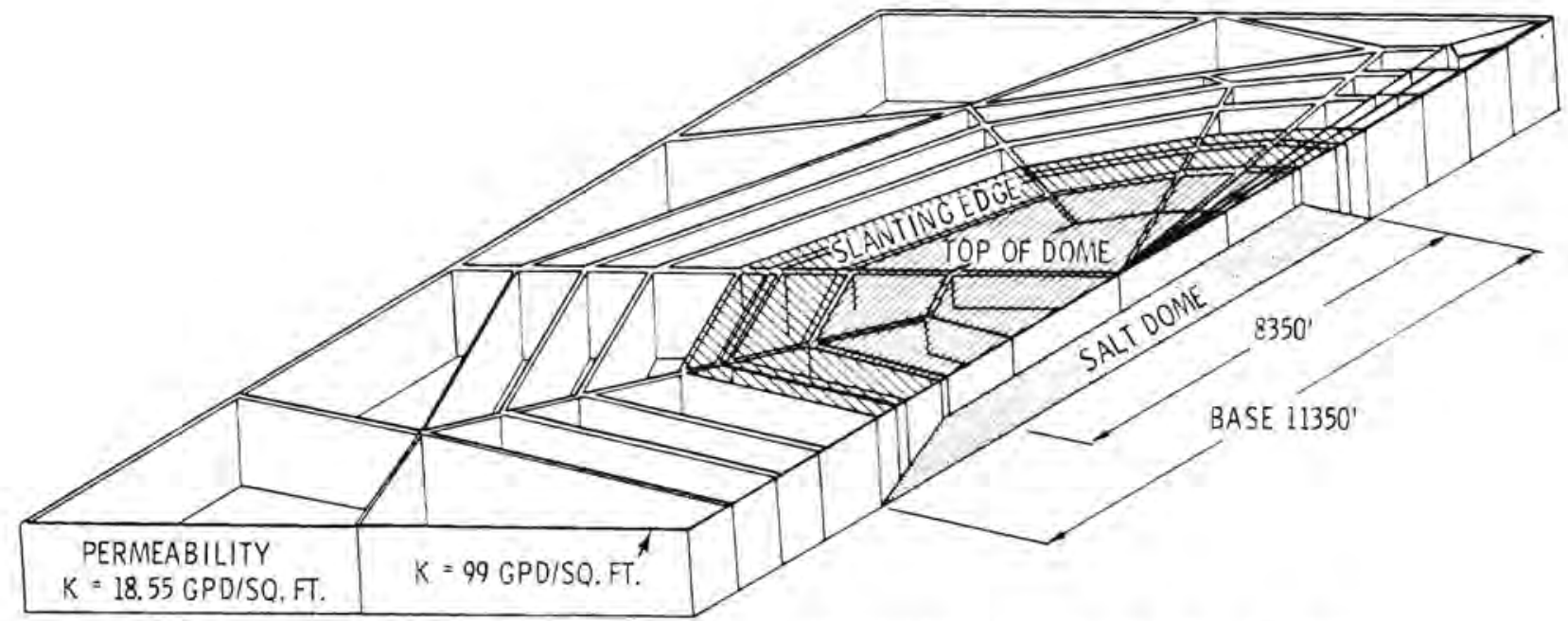

FIGURE 32. Three-Dimensional Stratifications of the Region Adjoining the Hainesville Salt Dome Used for Simulation of Flow Through Dome Breach

The model predicted a flow rate of $260 \mathrm{gpm}$ through the solution mine and out the breach. At $260 \mathrm{gpm}$ about 15,000 years would be required to dissolve the entire dome above the repository. This is a very conservative estimate from all aspects since abandoned, cased boreholes in unconsolidated materials, especially near the dome, would probably not remain open for 15,000 years. closure from clogging at the surface or corrosion failure is 1ikely. In addition, actual collapse of the solution mine is likely to occur much sooner and certainly long before the entire dome above the repository is dissolved.

For the collapsed salt dome phase of the abandonment scenario the solution mine cavity is filled with material having twice the permeability of the original Wilcox aquifer (Figure 33a). The Queen City aquifer and the lake (formed after collapse) provide an unlimited source of recharge with a 50-ft head across the entire cavity. The subregional boundaries and nodal system for modeling the collapse phase are shown in Figure 33b. Both the additional recharge to the wilcox as a result of collapse and lake formation and the rate of water flow past the waste were estimated. The estimate of flow past the waste was made by assuming the waste to be lying atop the remaining salt dome and by evaluating the flow through the 30-ft-thick layer of collapsed material above the new dome top. The flow in this layer was $35 \mathrm{gpm}$. 


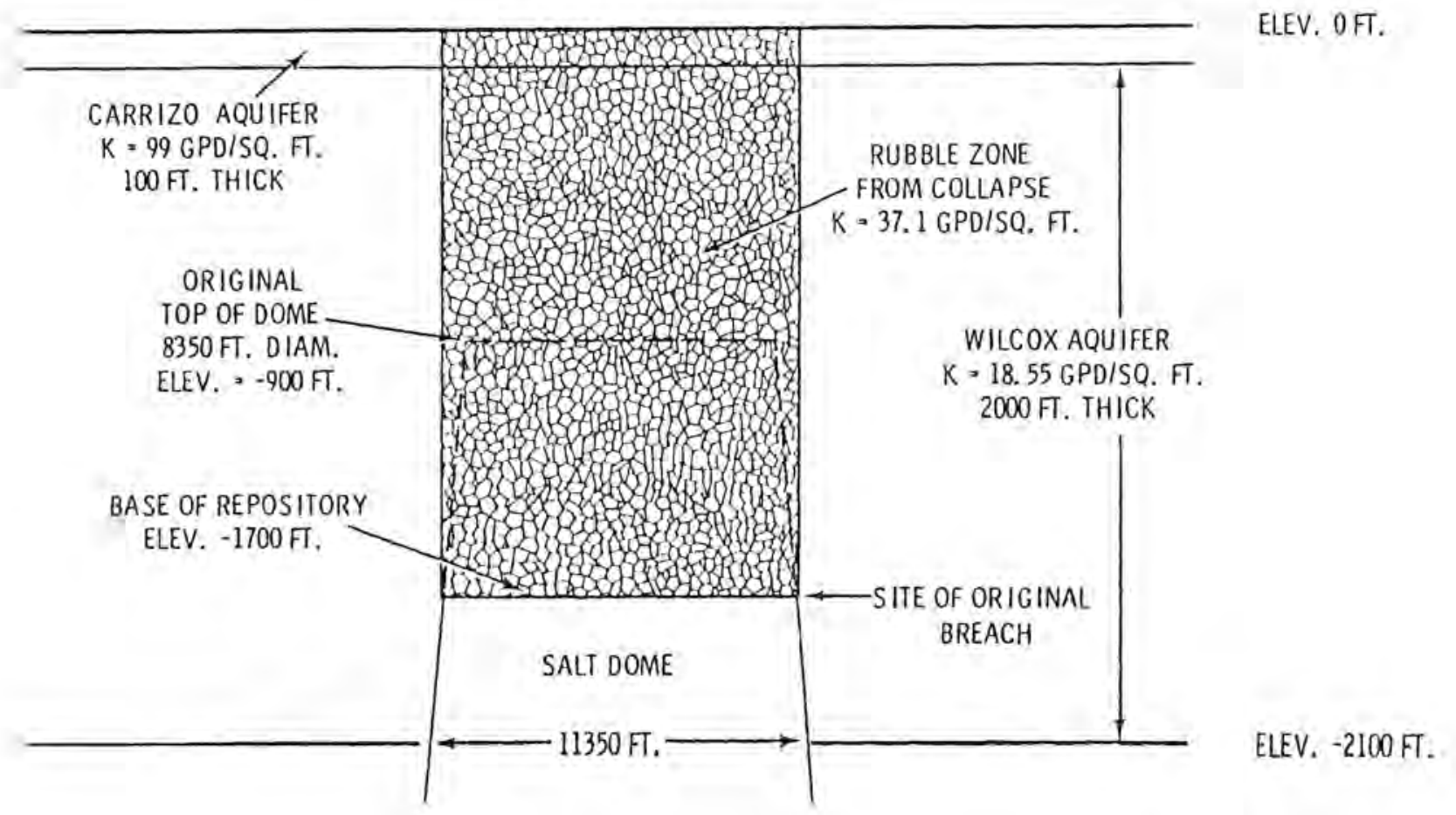

FIGURE 33a. Schematic Representation of Collapsed Hainesville Salt Dome

Once the flow rates through the repository had been determined, the steady-state VT model was used to simulate regional hydrologic ground-water movement through the Wilcox-Carrizo aquifer to the point of release to the biosphere. Specifically, the regional hydrology model was used to define the potential distribution, streamlines, flow tubes, and travel times.

A regular finite-difference grid with a node spacing of 2 miles was used to model an area $\sim 120$ miles by 130 miles. A two-layer system was modeled with the surface layer consisting only of streams and the Carrizo and Wilcox sands constituting the regional aquifer. This arrangement permits the use of an interaquifer transfer coefficient to control stream bed infiltration and thereby eliminates the need to assume that streams fully penetrate the aquifer.

The model boundaries were a combination of held and no-flow boundaries as shown in Figure 34. Flow patterns in the area are generally from northwest to southeast. Infiltration of rainfall influences the ground-water elevations in the region. Infiltration was adjusted in the unconfined areas to vary between $0.25 \mathrm{in}$. on the northwest edge to $0.9 \mathrm{in}$. on the eastern side. 
REGIONAL GROUND WATER FLOW

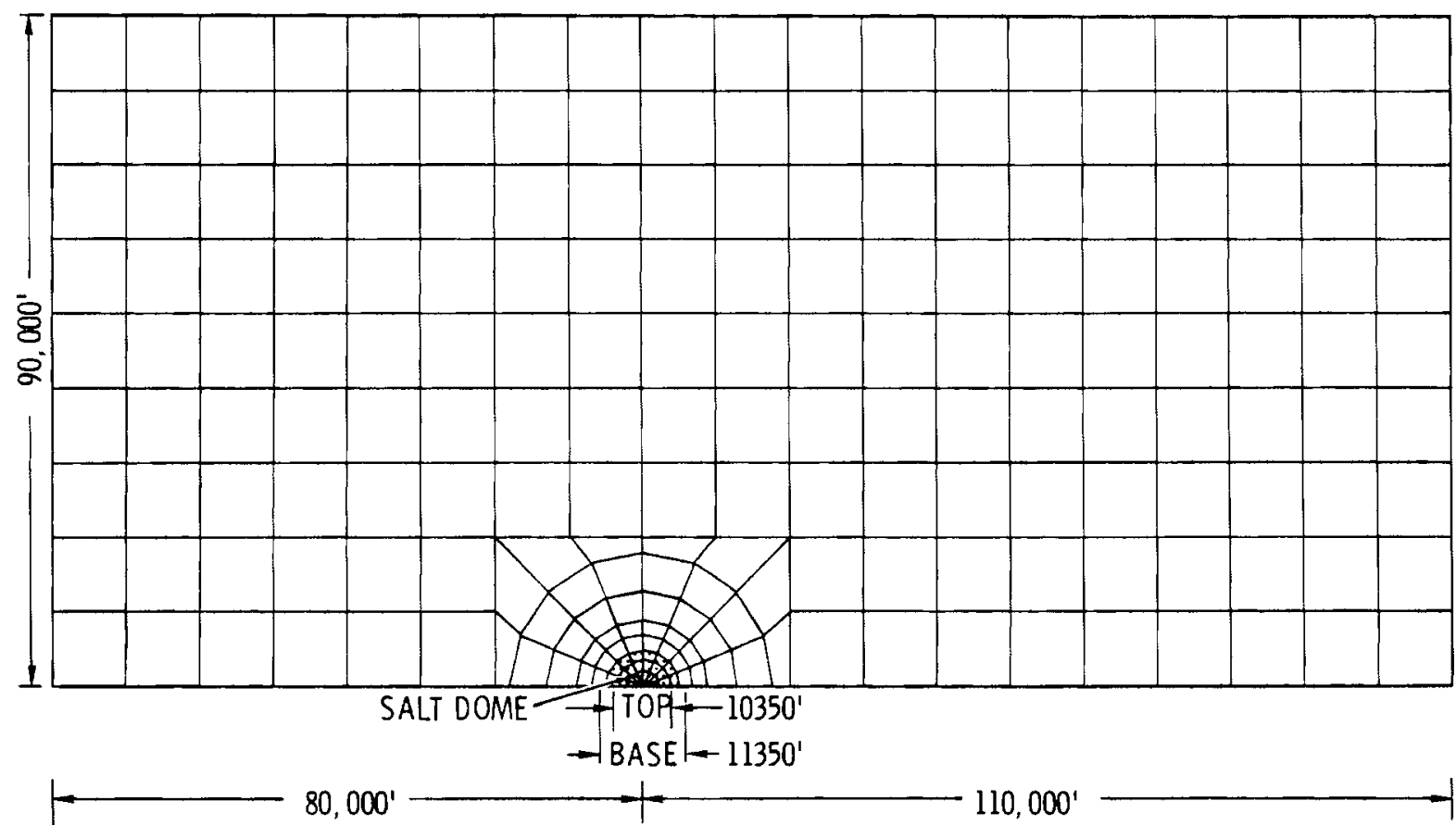

FIGURE 33b. Uniform Finite Element Grid for Simulation of Flow After Hainesville Salt Dome Collapse

Transmissivity data for the region are scarce. Consequently, a thickness distribution was developed using a map of the net sand that covers the confined areas and extrapolating these data to the boundaries. The average transmissivity for the sands, as determined from pumping tests, was divided by the thickness to arrive at an initial permeability distribution.

A potential surface for the Wilcox-Carrizo aquifer was drawn from 717 head measurements. This surface was used in calibrating the model.

Model results were presented for three different cases for the solution mining release scenario. The base case simulates essentially the present-day ground-water system. Flow originating at the salt dome travels southeast and then eastward into a large pumping depression, as shown in Figure 35 . This regional depression is caused by the pumping of 1 arge quantities of ground water in the East Texas $0 i 1$ Field area. For this case travel times ranged from 11,946 years to 18,795 years, with the flow tube lengths ranging from 183,000 to $219,000 \mathrm{ft}$. The average ground-water velocity was $13.3 \mathrm{ft} / \mathrm{yr}$. 


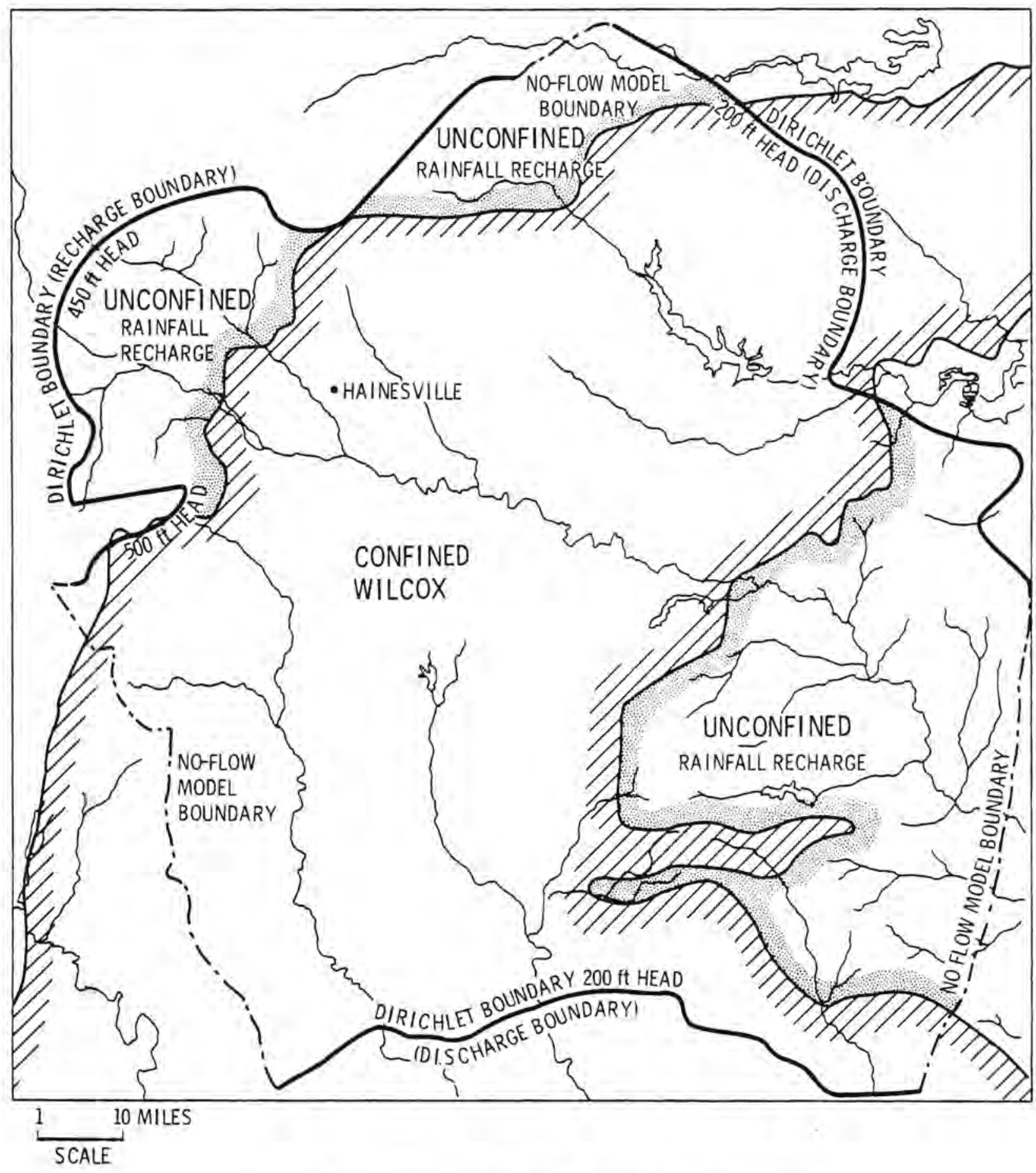

FIGURE 34. Geometry and Boundary Conditions

for the Wilcox-Carrizo Aquifer

(Hainesville Study) 


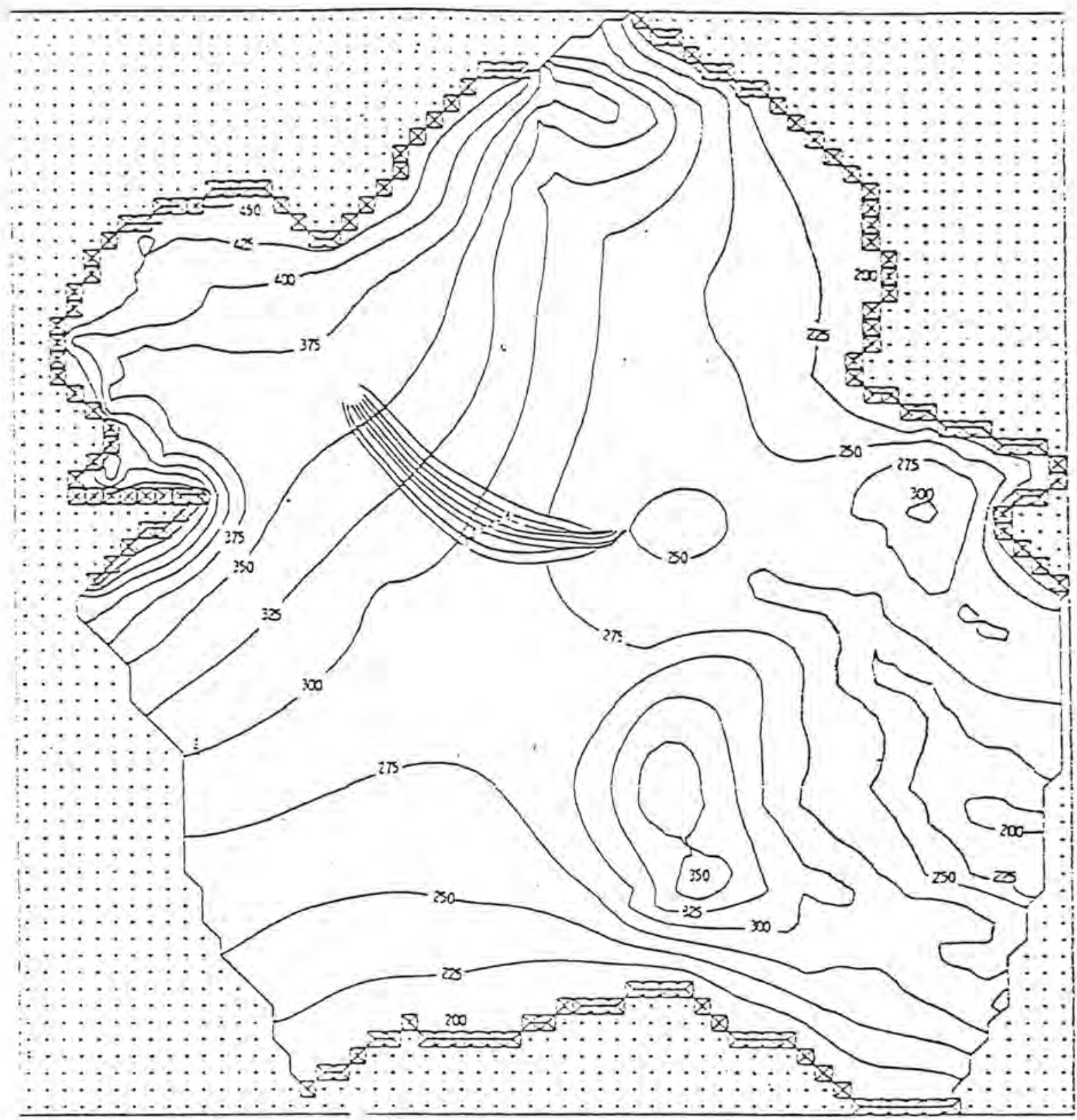

FIGURE 35. Modeled Ground-Water Aquifer Showing Potential Contours and Flow Tubes from the Hainesville Dome, Case 1 
The second case was postulated with the large pumping depression removed from the aquifer. This would permit the water originating at the dome to discharge into the Sabine River and the Big Cypress Bayou near the northeast boundary of the model as shown in Figure 36 . The ground-water travel times for this case range from 38,554 years to 43,015 years over distances ranging from $326,462 \mathrm{ft}$ to $343,411 \mathrm{ft}$. The average ground-water velocity was $8.3 \mathrm{ft} / \mathrm{yr}$.

In the third case a we $116 \mathrm{~km}$ down gradient from the dome pumps contaminated water at a rate of $400 \mathrm{gpm}$. Flow tubes were generated with an average length of 22,889 ft and an average travel time of $1050 \mathrm{yr}$.

\section{INFCE GRANITE HYDROLOGIC MODEL}

The FE3DGW flow model was used to model the multilayered granite geohydrologic system with discrete, highly fractured zones.

The generic geohydrology includes the major geologic and hydrologic features one would find at the reference granite repository site. (20) Figure 19 illustrates the boundaries of the reference repository site in granite along with the regional water table configuration and assumed boundary condition definitions. Although an actual site might contain some surficial layers of till and clay, these layers would tend to retard deeper circulation patterns and hence were ignored in our description so as to favor conservatism. The stratigraphy was thus assumed to be granite from the surface down. Recharge calculations were avoided by holding the water surface according to a subdued version of the actual topography. The reference topography decided upon was a version of an actual granite area modified slightly to be consistent with the assumed boundary conditions. Regional tilt is on an order of $10^{-3} \mathrm{~m} / \mathrm{m}$, and local topographic variations are from near zero to $10^{-1} \mathrm{~m} / \mathrm{m}$. The site shows a topography common for $g l a c i a t e d$ hard rock areas in Precambrian shields. The regional discharge site was assumed to be both large fresh water and salt water bodies. The boundary conditions include no-flow boundaries on the east and west, a vertical no-flow boundary to the south since this is assumed to be the regional ground-water divide, and a lake or ocean boundary to the north that is held at the lake or ocean elevation. Consistent with data observed for 


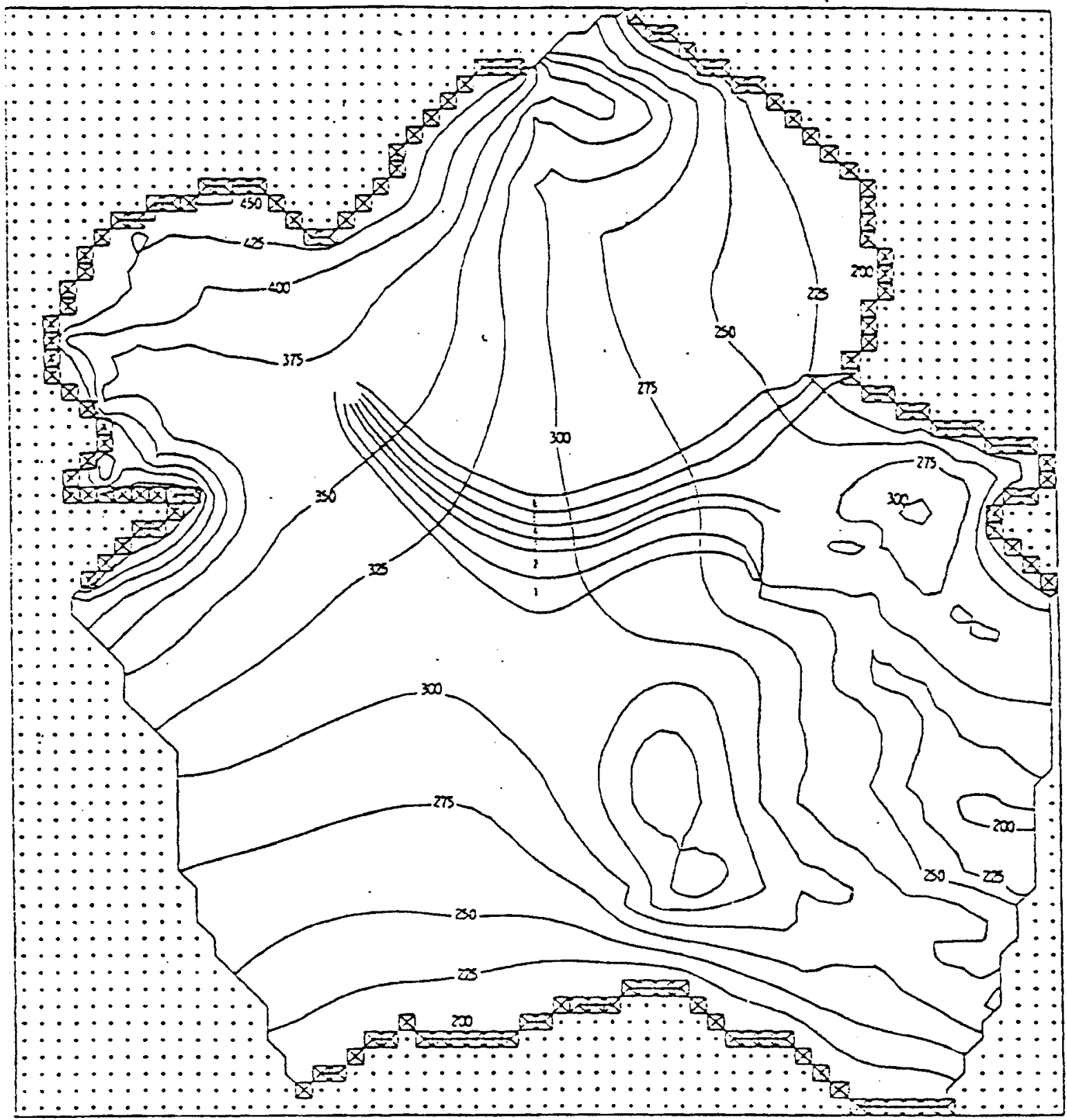

FIGJRE 36. Modeled Aquifer Showing Potential Contours and Flow Tubes from the Hainesville Dome, Case 2 
granite geologies, permeabilities and porosities decrease with depth. For modeling purposes, the upper $1.5 \mathrm{~km}$ is modeled in detail and the lowest layer is sufficiently thick to preclude interference by the assumed no-flow boundary along the lower surface.

Major shear or fracture zones in patterns like those observed in an actual granite area have been included. These fracture patterns at an actual site should be spaced so that blocks (undisturbed by major fracture or shear zones) of the appropriate size for repository siting are available. All major fracture zones are assumed to be vertical. In accordance with a generic stress distribution in the rock, the fracture zones are divided into tension, shear and compression zones.

The area used in the hydrologic model is 25,000 by $25,000 \mathrm{~m}$. The finite element grid representation of the area is shown in Figure 37 . Element size, shape and orientation were chosen to best represent the actual topography and structural properties of the granite mass within the modeled region. The regional ground-water divide to the south is 40 to $45 \mathrm{~m}$ above the level of the regional lake (or sea) elevation. The vertical boundary of the regional lake or sea is $\mathrm{placed}$ about $4000 \mathrm{~m}$ from the shoreline, and it is held at the same potential for all nodes. The major fracture zones are represented by discrete elements. The widths of these discrete elements were assigned according to the type of fracture zone. First and second order tension zones were assigned widths of 50 and $10 \mathrm{~m}$, respectively. Shear zones and compression zones were assigned widths of 20 and $5 \mathrm{~m}$, respectively. Table 11 gives the values of the hydraulic properties used in the different geohydrologic structures at the ground surface and at $500 \mathrm{~m}$ depth. The same slope is assumed for the different geohydrologic units, but they start at different surface values.

The output from the hydrologic model is the ground-water potential distribution throughout the modeled region. An auxiliary program for the FE3DGW model calculates the travel time, travel path, and travel distance along any streamline within the region. These values are calculated from the predicted potentials and from the input values used for permeability and porosity. Figure 38 illustrates the $X-Y$ paths that water would take starting at the upper left and right corners and in the middle of the repository as it proceeds to 


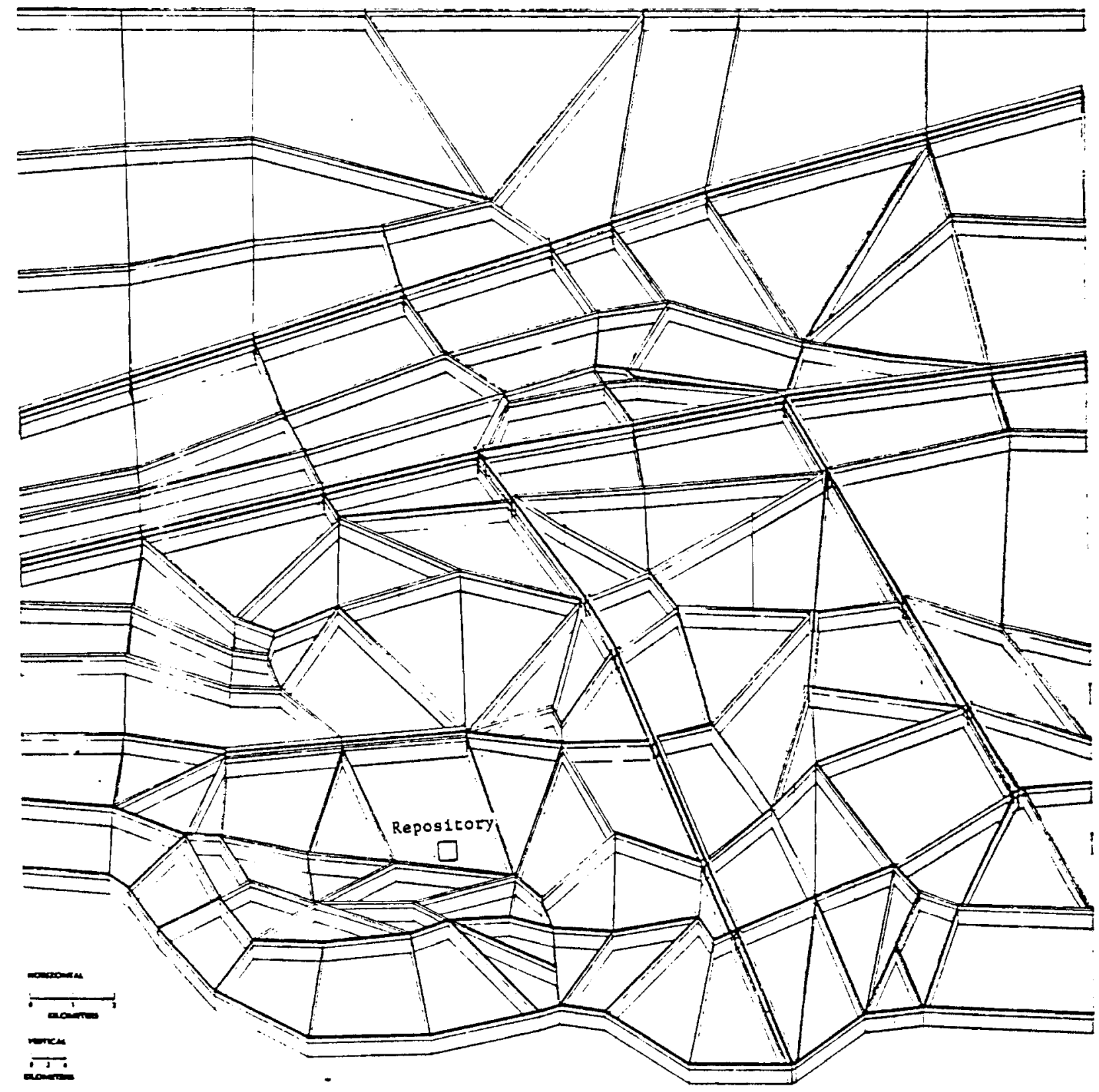

FIGURE 37. Finite Element Grid Representation of INFCE Granite Model Region 
TABLE 11. Hydraulic Properties of Different Hydrogeologic Structures in the Reference Repository Site Area in Granite

Water

Velocity Travel Time for

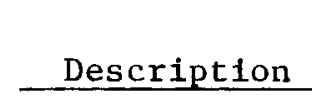

Rock Mass

First Order

Fracture Zones

(tension)

Second order

Fracture Zones

(tension)

Second Order

Fracture Zones

(shear)

Second Order

Fracture Zones

(compression)
$50 \mathrm{~m}$

$10 \mathrm{~m}$

Width

Depth

$1 \mathrm{~m}$

$\begin{array}{rr}1 & \text { m } \\ 500 & \mathrm{~m}\end{array}$

Permeability,

$\mathrm{m} / \mathrm{sec}$

$10^{-7}$

Porosity

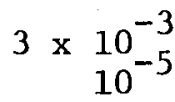

(unit gradient),

$\mathrm{m} / \mathrm{sec}$

$3.33 \times 10^{-5}$
$1 \times 10^{-5}$

$1 \mathrm{~km}$ under 0.001

gradient, yr

951

3170

$10^{-5}$
$10^{-8}$

$3 \times \begin{aligned} & 10^{-2} \\ & 10^{-4}\end{aligned}$

$3.33 \times 10^{-4}$

$500 \mathrm{~m}$

$10^{-5}$
$10^{-8}$

$3 \times \begin{aligned} & 10^{-2} \\ & 10^{-4}\end{aligned}$

$3.33 \times 10^{-4}$
$10^{-4}$

95

$500 \mathrm{~m}$

$5 \times 10^{-7}$
$5 \times 10^{-10}$

$5 \times 10^{-3}$

$1 \times 10^{-4}$

317

$500 \mathrm{~m}$

$.7 \times 10^{-5}$

$10^{-6}$
$10^{-9}$

$5 \times 10^{-3}$
$1.7 \times 10^{-5}$

$2 \times 10^{-4}$
$6 \times 10^{-5}$

159

529 


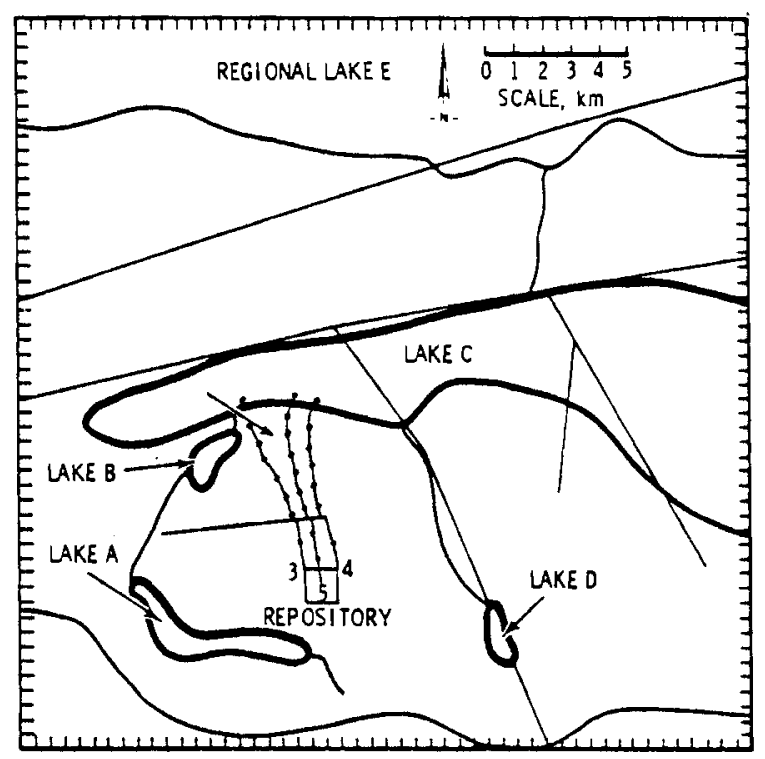

FIGURE 38. X-Y Paths for Streamlines Starting at the Upper Left and Right Corners of the INFCE Granite Repository as Well as the Middle. The dots along the streamline paths are placed 1000 years apart.

the discharge site in Lake $C$. The dots along the streamlines indicate 1000 years elapsed time. Notice that as the streamlines encounter the second order tension zone enroute to Lake $C$ they move upward and westward because of the higher permeability of the fracture and the disjuncture in gradients. The average streamline parameters are the following:

- distance - $7100 \mathrm{~m}$

- travel time - 11,700 yr $\pm 1300 \mathrm{yr}$

- velocity - $0.61 \mathrm{~m} / \mathrm{yr}$.

Since the transport is to be simulated with a one-dimensional model, the hydrologic model results must be reduced to an equivalent one-dimensional data set. The one-dimensional model requires a column length, pore water velocity, dispersion length, column width, column porosity, column height and column flow. The one-dimensional column parameters are related as follows:

Flow $=$ width $x$ height $x$ pore velocity $x$ porosity.

The flow through the repository was estimated from the average $X, Y, Z$ flux per unit area at the corners and middle of the repository. The resultant one-dimensional flow is $2.6 \mathrm{~m}^{3} / \mathrm{yr}$. 
The one-dimensional column width of $1600 \mathrm{~m}$ was estimated from $F$ igure 38 . Pore water velocity of $0.61 \mathrm{~m} / \mathrm{yr}$ is obtained from the quotient of the average streamline distance and travel time. A porosity estimate of 1.9E-4 was taken from the average of the time-weighted porosity along each of the five streamlines. The theoretical column height of $14.2 \mathrm{~m}$ was chosen to be consistent with the flow, width, velocity and porosity estimates. A column length of $7100 \mathrm{~m}$ ensures the appropriate average travel time for a velocity of $0.61 \mathrm{~m} / \mathrm{yr}$. Table 12 summarizes the one-dimensional column data required for the transport simulation.

TABLE 12. Summary of the Equivalent One-Dimensional Column Data Required of a One-Dimensional Simulation of Contaminant Transport

\begin{tabular}{ll}
\multicolumn{1}{c}{ Parameter Description } & Value \\
\cline { 1 - 2 } Column length, m & 7,115 \\
Column height, m & 14.2 \\
Column width, m & 1,600 \\
Column porosity (time-weighted average) (a) & $1.9 E-4$ \\
Column permeability (time-weighted average), (a) & $5.95 E-9$ \\
m/sec & \\
Column water velocity, m/yr & 0.61 \\
Minimum column dispersion length required & 42 \\
to account for dispersion resulting from \\
flow geometry, m \\
Column travel time, yr \\
Column flow, m 3 /yr
\end{tabular}

(a) Time-weighted porosity and permeability are needed in fracture flow systems to pick a representative $\beta$ value for calculating the retardation factor. 


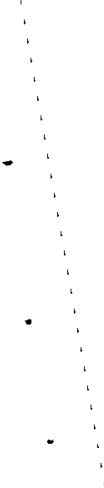




\section{MODEL ING OF ENGINEERED BARRIERS AND LEACH RATE}

One of the inputs required for a consequence analysis is an estimate of the rate that waste from a breached repository enters the regional hydrologic system. Realistic estimation of this rate, however, requires near-field modeling technology. As previously indicated, this has not been emphasized under the AEGIS program. As a result, generally, simple, overly conservative methods and models have been used to determine repository leach rates. For the following discussions, the repository leach rate is defined as the rate at which dissolved repository wastes leave the repository with its system of engineered barriers and enter the regional hydrologic system. The parameters and phenomena that can influence this repository leach rate function are the following:

- waste form

- canister design

- time of breach

- temperature

- local hydrologic flow patterns and actual quantity flowing past the waste

- diffusion, concentration gradients

- local geochemistry

- backfil1 geometry and composition

- geometry of repository and emplacement strategy

- local retardation factors

- other engineered barriers

- breach scenario

- composition of breaching waters.

In the studies discussed, typically only the waste form itself was given any credit for reducing leach rate. Except in the INFCE Granite Study, most of the positive effects of engineered barriers and repository design have been ignored; in that study the influence of the backfill was considered. 


\section{INFCE SALT LEACH MODEL}

The leach rate model utilized for the INFCE bedded salt reference repository breach was formulated during the earlier Paradox Study using preliminary data on the effects of flow rate and temperature on leach rate. The data from leaching experiments on crushed spent fuel $\left(3 \mathrm{~cm}^{2}\right.$ of geometric surface area per gram of fuel with a density of $10.2 \mathrm{~g} / \mathrm{cm}^{3}$ ) and $\mathrm{glass}$ waste indicated that the specific leach rates (grams leached $/ \mathrm{cm}^{2}$ of geometric surface area/day) vary from nuclide to nuclide. The data also indicated that for rates greater than one solution replacement (or flush) per year the specific leach rate is a function of the flushing rate. At less than one flush per year, the rates are essentially constant. The data on temperature effects available indicated that leach rates depend on temperature through an Arrhenius-type relationship. Finally, leach rate data comparisons between solid high-level waste and crushed high-level waste indicated that leach rates are dependent on the actual surface area but not directly proportional to it since the internal surface area of the crushed waste is not as effective in leaching. In the model, the highest specific leach rate was used for all nuclides, and the entire fuel rod or glass waste, including all drumed wastes, was assumed to leach congruently at that rate.

Figures 39 and 40 illustrate the leach functions used in the INFCE study. Table 13 shows the density, ambient temperature leach rate, initial geometric surface area per gram, and particle radius used by the leach model to generate the leach functions for the seven INFCE reactor strategies. The same temperature function versus time was used for all fuel cycles, and the same Arrhenius function was used to describe leach rate as a function of temperature. For the INFCE salt study the entire content of the repository was available for leaching due to the severity of the release scenario modeled. Canisters were assumed to fail simultaneously at the time of breach, and backfill was assumed to have no effect on leach rate.

\section{PARADOX BAS IN LEACH MODEL}

The same leach rate model and leach rate function (Figure 39) used in the INFCE bedded salt study was used for the Paradox Basin bedded salt. Again, 


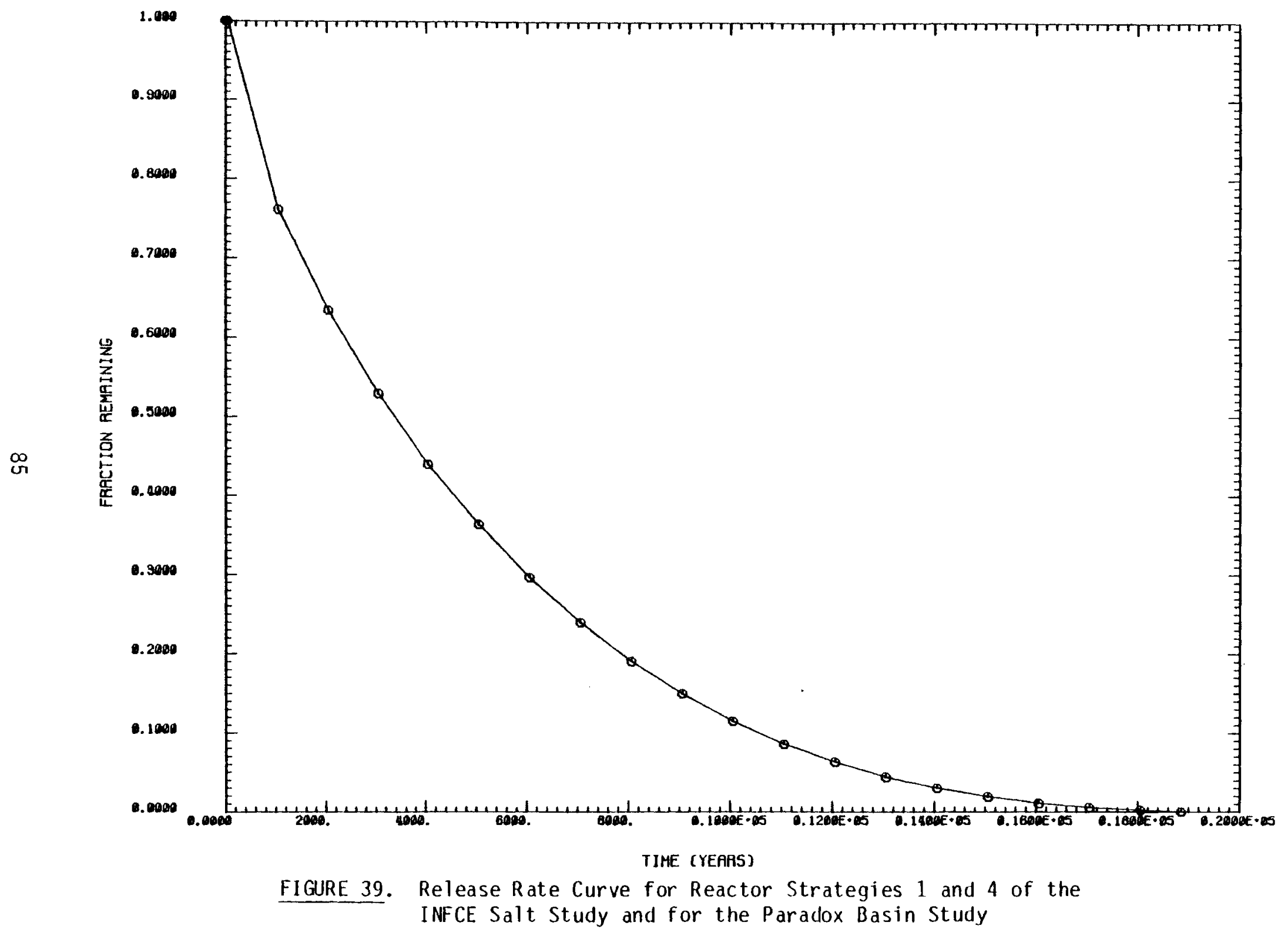




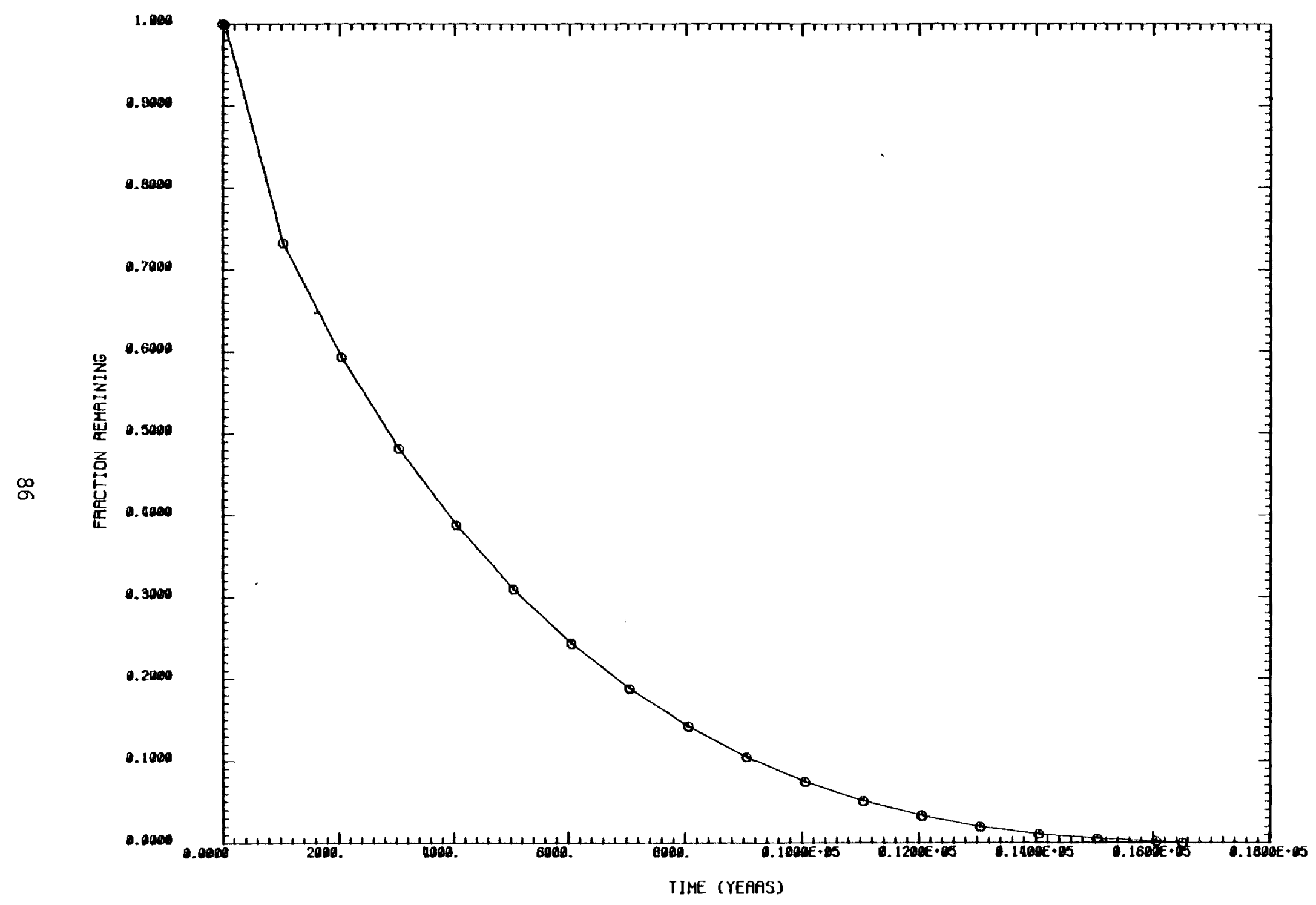

FIGURE 40. INFCE Salt Study Release Rate Curve for Reactor Strategies $2,3,5,6$, and 7 
TABLE 13. Parameters Used by the Leach Model to Generate the Leach Rate Functions Shown in Figures 39 and 40

\begin{tabular}{|c|c|c|c|c|}
\hline $\begin{array}{l}\text { Paradox Basin } \\
\text { and INFCE } \\
\text { Reactor } \\
\text { Strategies } \\
1 \text { and } 4\end{array}$ & 10.2 & 5.E-8 & 3.0 & 0.098 \\
\hline $\begin{array}{l}\text { INFCE Reactor } \\
\text { Strategies } \\
2,3,5, \\
6 \text {, and } 7\end{array}$ & 3.3 & 4.E-7 & 0.424 & 2.14 \\
\hline
\end{tabular}

the highest specific leach rate was used, and all nuclides in the spent fuel rods were assumed to leach at this rate. It was assumed that all spent fuel (1000 MTHM) in the repository area fractured by the fault was available for leaching. Again, it was assumed that the waste cans failed simultaneously at the time of breach and that other engineered barriers had no effect on leach rate.

\section{HAINESVILLE LEACH MODEL}

The same type of leach rate model used in the bedded salt studies was employed in the salt dome study. Additional results, however, from spent fuel leach tests using generic solutions, as well as some more recent literature data, were incorporated. The principle underlying the development of this leach rate model is that the dissolution rate would depend on the leach rate constant until the solubility limit is reached. From then on, the dissolution rate would be governed solely by the solubility of elements. The uranium solubility was limited at $6 \mathrm{ppm}$ at the assumed ground-water composition and temperature in the revised model, and on the basis of congruent dissolution data this limit controlled the release of the other isotopes. The fraction of waste exposed that is needed to reach solubility limits is shown in Figure 41 as a function of flow rate and leach rate constant. For Hainesville the source term was calculated to be solubility-limited within 1.5 years after 


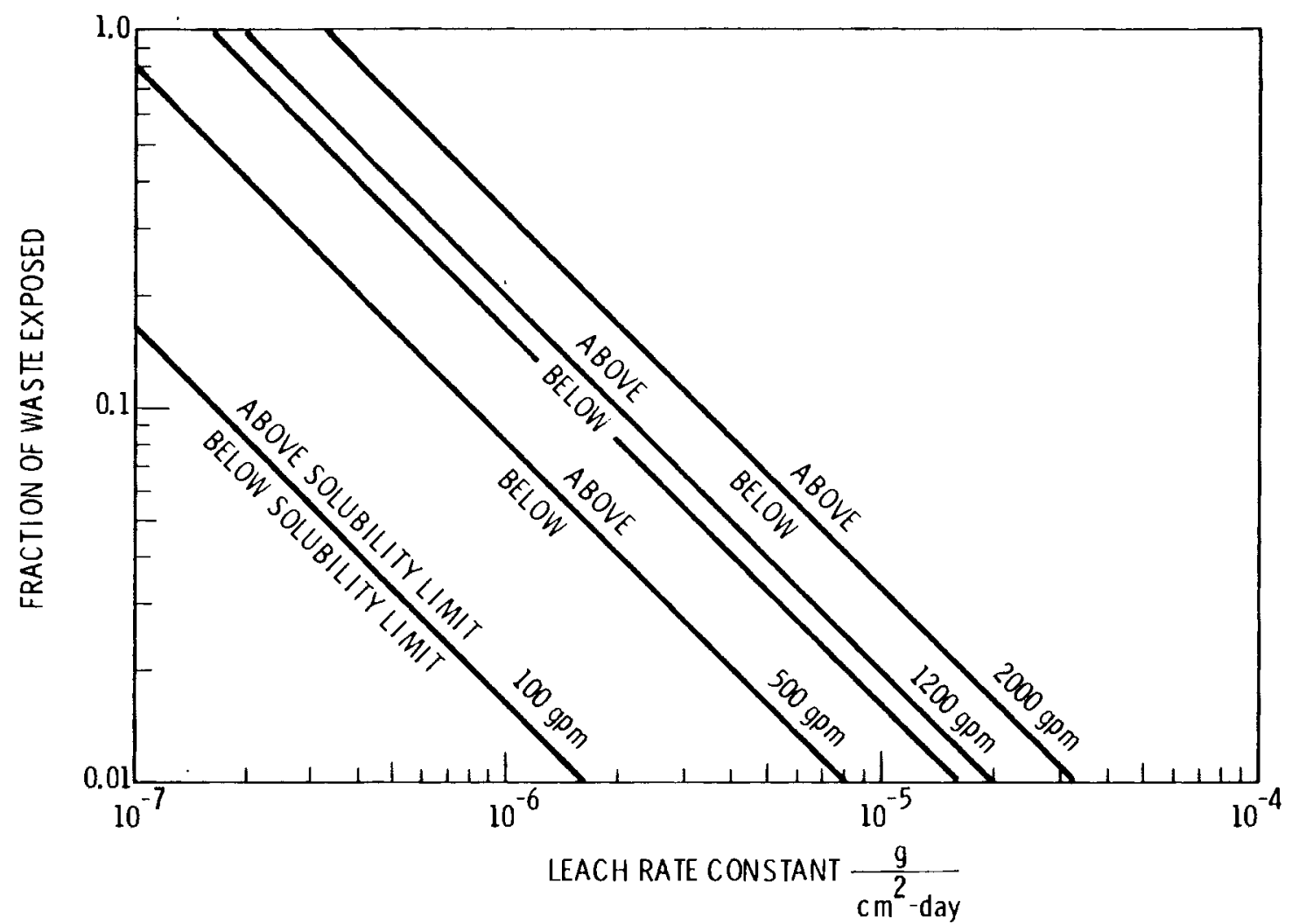

FIGURE 41. Fraction of Waste Exposed Needed To Reach Solubility Limits for Specific Flow Rates and Leach Rate Constants (Hainesville Salt Dome) 
repository breach by solution mining. During the operational part of the solution mining scenario $0.97 \%$ of the waste was leached. The remaining waste content of the repository was leached during the two phases of the postoperational part of the solution mining scenario. As in the INFCE salt and the Paradox Basin studies, canisters and any other engineered barriers other than the waste form itself were given no credit in reducing leach rate or delaying the onset of release.

\section{INFCE GRANITE LEACH MODEL}

The high-level waste packages to be buried in the granite repository include two major waste forms: unreprocessed spent fuel and vitrified reprocessing waste. Because spent fuel is predominantly uranium oxide, it was assumed that dissolution of spent fuel occurs at a rate corresponding to the solubility-limited diffusion of uranium. Other radionuclides are released in proportion to their concentrations relative to uranium. It was assumed that release of spent fuel will begin at 100 years at a temperature of $65^{\circ} \mathrm{C}$, when a 11 canisters fail simultaneously. As the temperature decreases to near background in the first few thousand years, the release rate similarly drops. Hence, the release rate as a function of time shows an initial "peak" a few thousand years wide followed by an extended "plateau" hundreds of thousands of years wide.

The dissolution of vitrified waste within a diffusion barrier is less straightforward to analyze because no constituent dominates as does uranium in spent fuel. Since silica is usually a major constituent of vitrified waste, and its hydrolysis is closely related to glass leaching, it was assumed that the release from vitrified waste within a diffusion barrier is that corresponding to the diffusion of amorphous hydrated silica. Other species are being released in proportion to their concentration relative to silica. The release rate for vitrified waste will decrease rapidly from an initial maximum as the temperature decreases.

The non-high-level wastes are packaged in drums. These wastes are more difficult to analyze because the disposal concept for them is less well developed and the waste forms are not specified in detail, nor are they optimized. 
A crude estimate of the release rate for these waste categories was made by assuming that the contained waste was dissolved to saturation in the available amount of ground water.

For either spent fuel, vitrified waste, or waste in drums, release of radionuclides is from the waste form through a compacted bentonite backfi11, and into ground water within rock fissures. Canisters of spent fuel and vitrified waste (both packaged) are emplaced in individual holes; for this case the release rate can be estimated by taking into account the resistance of the bentonite buffer to mass transfer.

Neretnieks ${ }^{(32)}$ has estimated the mass transfer resistance of homogeneous bentonite annuli fitted inside a hole in fractured rock. On absorbing water, bentonite swells and exerts pressure on its surroundings. Confined in a hole, the bentonite fills gaps and interstices, so that the assumption of homogeneity is reasonable. The canisters are designed to resist the pressure. Following Neretnieks, it is assumed that the hole intercepts a set of parallel horizontal fissures in which ground water flows around the bentonite annulus. Because of compacted bentonite's very low permeability it is assumed that water flow in the bentonite is too small to increase mass transfer much beyond that due to diffusion alone. The swelling bentonite will probably intrude into the fissures, thereby extending the buffer region and its attending mass transfer resistance; however, since the extent of intrusion is difficult to estimate, it is assumed that no intrusion occurs.

The ion-exchange capacity of bentonite can further inhibit release by retaining the shorter-lived or more strongly adsorbed radionuclides long enough for significant radioactive decay to occur. However, any such adsorptive retention must necessarily be preceded by release of canister corrosion products to the bentonite, which might become adsorbed and thereby reduce the exchange capacity. For this reason, no ion-exchange capacity for the bentonite is assumed; however, any retention of canister corrosion products is not expected to affect the mass transfer resistance described above.

For this study it was assumed that relatively inexpensive stainless steel canisters and drums are used that last on ly 100 years. This fixes the time 
elapsed before release begins. As has been shown, however, by the Swedish KBS study, $(8,9)$ more expensive canisters can be designed to last for thousands of years or longer. One advantage thus gained is that the canisters will fail over thousands of years, or longer; this would disperse any "pulse" release of unbound radionuclides over a long period and thus reduce the radionuclide concentration in flowing repository ground water. Realistically, failures of the "100 year" canisters assumed for this study would be distributed over many years, but for the purpose of this study, simultaneous failures were assumed. 


\section{TRANSPORT MODELING}

The hydrologic models predict water flow paths and travel times, and the engineered barrier and leach rate models predict the length of time and rate at which contaminants enter the regional ground water from the breached repository. The next step in the modeling sequence is to use a transport model to predict the movement of the radionuclides in the ground water, through the geosphere, and eventually into the biosphere.

For contaminant transport simulation, three of the studies $(1,3,4)$ used the one-dimensional Multicomponent Mass Transport (MMT) code. (33) The MMT code considers simple radioactive decay, linear chain decay, branched chain decay, and retardation from soil/nuclide interactions. The method of solution is to simulate the physical phenomena causing mass transport in ground-water aquifers. Convection is simulated by attaching mass to a parcel and moving that parcel a distance calculated by the product of the local ground-water velocity and the current time step (Discrete Parcel Random Walk). Dispersion is simulated by using random numbers between -1 and 1 multiplied by a length factor, the time step, and the dispersion constant.

The data requirements for the MMT code include the following:

- retardation coefficient

- dispersion

- half-lives for all nuclides

- path length

- ground-water velocity

- flow tube size

- initial inventory

- time after repository closure when the breach occurs

- leach information to control entry of waste into ground-water system

- a map that illustrates the parent-daughter relationships. 
The retardation coefficient, $K$, is calculated from the soil-to-solution ratio, $B\left(\frac{\mathrm{g}}{\mathrm{mT}}\right)$ and the distribution coefficient, $\mathrm{K}_{\mathrm{d}}\left(\frac{\mathrm{ml}}{\mathrm{g}}\right)$ by Equation 1 :

$$
K=1+B K_{d}
$$

$B$, the soil-to-solution ratio, is a ratio of the bulk density divided by the porosity for porous media and a more complex function for fracture flowdominated media. (2) $k_{d} s$ are estimated based on rock type and water composition or from laboratory measurements or field in situ tests. The path length and ground-water velocity were obtained from the hydrologic model.

If desired, the one-dimensional code can be used for pseudo two-and-threedimensional simulations. Flow tubes equal in flow rate can be determined from the hydrologic model. Each flow tube has a different characteristic velocity and path length to the river. A one-dimensional solution would then be obtained for adjacent sets of flow tubes. Outputs from the MMT code are nuclide concentrations in the ground water as a function of time or the rate of biosphere arrival versus time.

\section{INFCE SALT TRANSPORT MODEL}

The input to the MMT code was derived from the output of the hydrologic and leach rate models. Because of time constraints of the study, the MMT code was run with a single average flow tube rather than for multiple flow tubes. Average values of velocity, path length, width, and travel time from the multiple flow tubes were used to describe a single flow tube. Retardations for the nuclides were estimates based on the generic geology and brine ground waters.

Table 14 summarizes the transport model input parameters for all seven reactor strategies. From the overall repository inventories, only those isotopes that would have any measurable inventory after 10,000 years were selected for study because travel time to the river was $10^{5}$ years for water alone. Isotopes not involved in chain decay schemes can be followed one by one through the flow system. These isotopes include the fission products and 
TABLE 14. INFCE Salt Study Transport Model Input Parameters for all Seven Reactor Strategies Modeled*

\begin{tabular}{|c|c|c|c|c|c|c|c|c|c|c|}
\hline ISOTUPE & $\begin{array}{l}\text { HALF-LITE } \\
\text { (YEARS) }\end{array}$ & $i_{(W L / G)}$ & 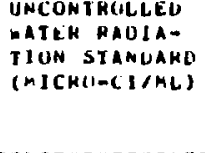 & 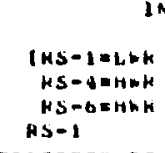 & $\begin{array}{l}\text { MYETTU } \\
\text { SPENT } \\
\text { UNCE } \\
\text { OITH } \\
\text { HS-2 }\end{array}$ & $\begin{array}{l}\text { UHY AT } 10 \text { YEAHS } \\
\text { CROH } \\
\text { TUEL, HS-2=LHR } \\
\text { THKU, HS-SEHWR } \\
\text { PU-IH RECYCLE, } \\
\text { HS-3 }\end{array}$ & 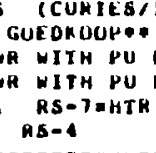 & $\begin{array}{l}\text { IUOGW(E)YS } \\
\text { HECYCLE, K } \\
\text { HECYCLE, } \\
\text { WITH UITH } \\
\text { KE-S }\end{array}$ & 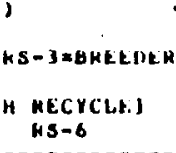 & AS-7 \\
\hline $\begin{array}{c}94-T C \\
129-1 \\
135-C S\end{array}$ & $\begin{array}{l}2.1365 \\
1.5967 \\
2,30 E 6\end{array}$ & $\begin{array}{l}1.9 \\
i^{3}, 0\end{array}$ & $\begin{array}{l}3.0 k-1 \\
0.0 k-1 \\
1.06-1\end{array}$ & $\begin{array}{l}5.004 \\
1 \text { io. } \\
\text { y20. }\end{array}$ & $\begin{array}{l}\text { Sjukt } \\
\text { ija. } \\
1200 .\end{array}$ & $\begin{array}{l}\text { A2.4 } \\
\text { y400. }\end{array}$ & $\begin{array}{l}3.514 \\
120 . \\
380^{\circ}\end{array}$ & $\begin{array}{l}3.554 \\
130 . \\
300 .\end{array}$ & $\begin{array}{l}1.454 \\
190 . \\
620 .\end{array}$ & $\begin{array}{l}3.32] \\
120 . \\
470 .\end{array}$ \\
\hline $\begin{array}{l}240-P U \\
236-0 \\
238-t+1 \mathrm{TH}\end{array}$ & $\begin{array}{l}\text { CS40. } \\
2.30 E 7 \\
1.4510\end{array}$ & $\begin{array}{l}40 . \\
2.9 \\
10 .\end{array}$ & $\begin{array}{l}5.0 E-6 \\
3.0 E-5 \\
2.0 E-6\end{array}$ & $\begin{array}{l}1.6256 \\
y 10 . \\
\text { u. }\end{array}$ & $\begin{array}{l}\text { Sities } \\
\text { s.4 }\end{array}$ & $\begin{array}{l}2.0763 \\
\text { o.376 } \\
\text { o. }\end{array}$ & $\begin{array}{l}\text { B.756 } \\
\text { yis. } \\
\text { o. }\end{array}$ & $\begin{array}{l}\text { 3.06E5 } \\
\text { 130. } \\
\text { o. }\end{array}$ & $\begin{array}{l}4.654 \\
26.0 \\
14.2\end{array}$ & $\begin{array}{l}\text { l.04k4 } \\
\text { 301. } \\
1.6\end{array}$ \\
\hline $\begin{array}{l}231-A K \\
233=-N P \\
233-U \\
229-T H\end{array}$ & $\begin{array}{l}\text { B3. } \\
2,1 \text { ice } \\
1,3015 \\
1340 .\end{array}$ & $\begin{array}{l}1130 . \\
23 . \\
2.9 \\
00 .\end{array}$ & $\begin{array}{l}1.0 E-6 \\
3.0 E-6 \\
3.0 E-3 \\
1.0 E=6\end{array}$ & $\begin{array}{l}1,24 k 7 \\
1200 . \\
120 \\
u\end{array}$ & $\begin{array}{l}\text { ligeto } \\
\text { isoo. } \\
0 . \\
0 .\end{array}$ & $\begin{array}{l}30106 \\
392 . \\
0 . \\
0 .\end{array}$ & $\begin{array}{l}\text { liojer } \\
\text { ji2. } \\
\text { o.: } \\
0 .\end{array}$ & $\begin{array}{l}\text { ojites } \\
\text { jii. } \\
\text { o. } \\
0 .\end{array}$ & $\begin{array}{l}2.43 E S \\
\text { a5o. } \\
2,0 E 4 \\
16 .\end{array}$ & $\begin{array}{l}1.1665 \\
860 . \\
3400 \\
1.9\end{array}$ \\
\hline 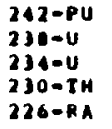 & 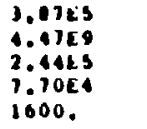 & $\begin{array}{l}80 . \\
2.9 \\
2.9 \\
00 \\
0.9\end{array}$ & $\begin{array}{l}3.0 t=6 \\
4.0 E-5 \\
3.0 E-5 \\
2.0 E-6 \\
3.0 E-6\end{array}$ & $\begin{array}{l}\text { souv. } \\
\text { 6ojus: } \\
\text { olsu. } \\
0 . \\
0 .\end{array}$ & $\begin{array}{l}110 \\
100 \\
130 . \\
0 . \\
0 .\end{array}$ & $\begin{array}{l}319 . \\
11.0 \\
640 . \\
0.0 \\
0 .\end{array}$ & $\begin{array}{l}3090 \\
6000 \\
3,16 j \\
0 . \\
0 .\end{array}$ & $\begin{array}{l}011 . \\
2.5253 \\
2030 . \\
0 . \\
0 .\end{array}$ & $\begin{array}{l}52 . \\
229 \\
3930 . \\
014 \\
0 .\end{array}$ & $\begin{array}{l}100 . \\
1060 . \\
1000 \\
5300 \\
50 \\
0 .\end{array}$ \\
\hline $\begin{array}{l}243-A N \\
239-P U \\
233-0 \\
231-P A\end{array}$ & $\begin{array}{l}1370.4 \\
2.6164 \\
3.0460 \\
3.2364\end{array}$ & $\begin{array}{l}1130 . \\
80 . \\
209 \\
100 .\end{array}$ & $\begin{array}{l}4.0 E-6 \\
9.0 E-6 \\
3.0 E-5 \\
9.0 E-7\end{array}$ & $\begin{array}{l}0.4364 \\
11160 \\
126 . \\
0 .\end{array}$ & $\begin{array}{l}2, \text { UES } \\
\text { ?.uE: } \\
\text { iy. } \\
0 .\end{array}$ & $\begin{array}{l}1.5 E 9 \\
1, A k s \\
0.13 \\
0 .\end{array}$ & $\begin{array}{l}63000 \\
2.916 \\
96 . \\
0 .\end{array}$ & $\begin{array}{l}1.5 \mathrm{ks} \\
1,354 \\
23 . \\
0 .\end{array}$ & $\begin{array}{l}110 . \\
1: 984 \\
3,0 \\
r .0\end{array}$ & $\begin{array}{l}2400 . \\
5600 . \\
26 . \\
0 .\end{array}$ \\
\hline
\end{tabular}

- a dispegsion length of 10 ft mas used ruk all cases and a beta of 11.5 
the activation products. The actinides, however, are involved in essentially four decay chains and were modeled as chain decay processes.

To properly represent the transport of the radionuclides, the model was run until all isotopes either reached the river or decayed to negligible mass. The results, as sumarized in Table 15, were reported as maximum concentration in the ground water and in the biosphere river, as well as the ratio of these maximum concentrations to the uncontrolled water radiation standard MPC. ${ }^{34)}$ An asterisk (*) after the ratio value indicates that the MPC was exceeded.

For all seven reactor stategies, only three of the 15 fission products $\left({ }^{99} \mathrm{TC},{ }^{129} \mathrm{I}\right.$, and ${ }^{135} \mathrm{Cs}$ ) arrive at the river. The other fission products decay along the flow path. Of the three fission products reaching the river, and for all seven reactor strategies, on ly the ${ }^{129}$ I has a ground-water concentration greater than its MPC, and ${ }^{129} I$ is the first isotope to reach the river. For this particular scenario, and for all seven reactor strategies, the 129 I peak ground-water concentration arrives at the river about 670,000 years after the release from the repository. The ${ }^{129}$ I concentrations at the peak range from 27 to 61 times greater than MPC, with Reactor Strategy 3 having the lowest peak concentration and Reactor Strategy 6 having the highest. For all seven reactor strategies, the two remaining fission products take well over one million years to arrive at the river, and their peak concentrations are at least 250 times below MPC. The only exception is for Reactor Strategy 3, where ${ }^{135} \mathrm{Cs}$ has a peak concentration in the ground water that is 0.25 of MPC.

of the 16 actinides modeled, only the ${ }^{226} \mathrm{Ra}$ arrives at the river with a ground-water concentration greater than MPC for all seven reactor strategies. For this particular scenario, and for all seven reactor strategies, the ${ }^{226} \mathrm{Ra}$ peak ground-water concentration arrives at the river about 3.4 million years after release from the repository, and the peak concentrations range from 2.5 to 1500 times greater than MPC. Reactor Strategy 3 has the smallest peak concentration, while Reactor Strategy 1 has the 1 argest. For all seven reactor strategies, the plutonium and the americium decay before reaching the river and al1 remaining actinides arrive at the river in concentrations ranging from 
TABLE 15 Surmary of the INFCE Transport Model Results of the Seven Reactor Strategies

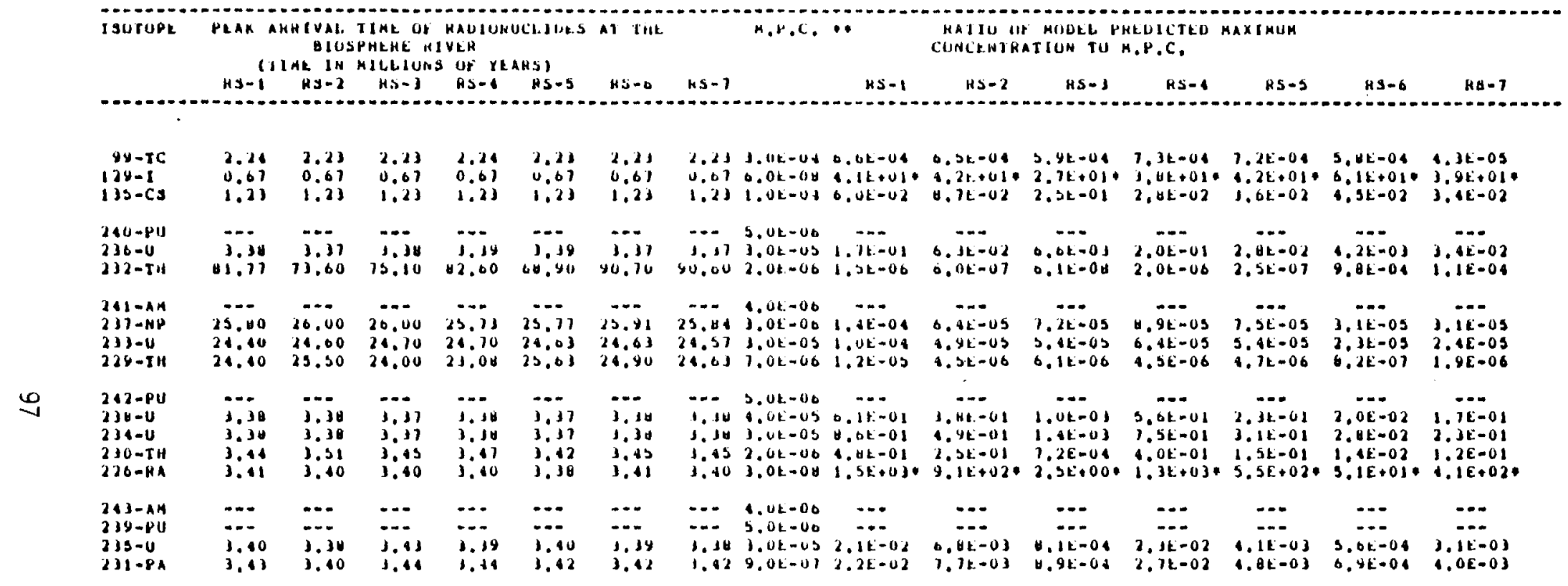

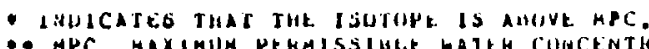

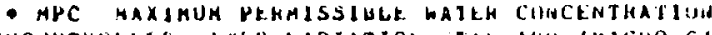

(1)

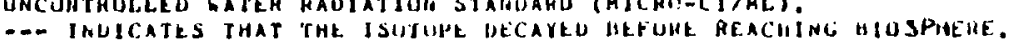


0.87 times MPC $\left({ }^{234} \mathrm{U}\right.$ in Reactor Strategy 1$)$ to $6.2 \times 10^{-8}$ times MPC $\left({ }^{232} \mathrm{U}\right.$ in Reactor Strategy 3 ). Peak arrival times for the actinides range from 3.4 million years to 91 million years.

All of the above concentrations should be put in proper perspective: note that the brine-saturated ground water is about 1000 times above the recomnended drinking water standard for salt content. Moreover, when the ground water reaches the river, it will be diluted by a factor of $10^{5}$ to $10^{7}$, making it well below MPC.

\section{PARADOX BASIN TRANSPORT MODEL}

The hydrologic model was used to determine five flow tubes equal in flow (Figure 29), each of which has different ground-water travel times and path lengths, for waste moving from the repository to the Colorado River. Contaminant movement was modeled in all five of the flow tubes. MMT code input parameters are summarized in Table 16.

As in the INFCE Salt transport modeling, only those radioisotopes remaining in significant amounts after 10,000 years were selected for study because travel times to the river for the water alone were greater than $4 \times 10^{4}$ years. Similarly, isotopes not involved in chain decay (fission and activation products) were followed one by one through the flow system, whereas the actinides were followed in four decay chains.

The model results were reported in three formats:

- as a plot of the nuclide concentration $(\mu \mathrm{Ci} / \mathrm{ml})$ in the ground water (which enters the river) versus time for each flow tube

- as a plot of maximum (composite of the five flow tubes) nuclide concentration $(\mu \mathrm{Ci} / \mathrm{ml})$ in the ground water (which enters the river) versus time

- as a plot of concentration in the ground water versus distance for the actinides which have not reached the river in two million years.

Three fission products, ${ }^{99} \mathrm{Tc},{ }^{129} \mathrm{I}$, and ${ }^{135} \mathrm{Cs}$, arrive at the Colorado River in concentrations exceeding $10^{-10} \mathrm{\mu Ci} / \mathrm{ml}(0.01$ of the most restrictive levels for uncontrolled drinking water use). When dilution in the river is accounted for, their concentrations are reduced by a factor of $1.2 \times 10^{-5}$. 
TABLE 16. Radionuclides Modeled by the Transport Code in the Paradox Basin Study

\begin{tabular}{|c|c|c|c|}
\hline $\begin{array}{l}\text { HALF LIFE, } \\
\text { YEARS. }\end{array}$ & $K_{d}, m \ell / 9$ & $\begin{array}{c}\text { UNCONTHOLLED } \\
\text { WATER } \\
\text { AADIATION } \\
\text { STANDARD, } \\
\mu \mathrm{Ci} / \mathrm{ML}\end{array}$ & $\begin{array}{c}10 \text { YEAR } \\
\text { INVENTORY, } \\
\text { CURIES/MTHM }\end{array}$ \\
\hline 8. $0 E+4$ & 50. & $2.0 \mathrm{E}-4$ & 3.03 \\
\hline $6.5 E+4$ & 2. & $3.0 \mathrm{E}-4$ & $3.5 E-1$ \\
\hline 4. $7 E+10$ & 1.0 & $1.0 \mathrm{E}-4$ & 1.7E-5 \\
\hline $3.0 E+3$ & 15. & $2.0 \mathrm{E}-4$ & 7.3E-3 \\
\hline $2.0 E+4$ & 80 & $1.0 E \cdot 4$ & $1.0 E-4$ \\
\hline $9.5 E \cdot 5$ & 80. & B. OE-4 & 1.79 \\
\hline $2.13 E+5$ & 1.9 & $3.0 \mathrm{E}-4$ & 13.007 \\
\hline $6.5 E+6$ & 38 & $9.0 E-5$ & $9.9 E-2$ \\
\hline $1.0 E+5$ & 80 & $2.0 \mathrm{E}-5$ & .48 \\
\hline $1.59 E+7$ & .5 & $6.0 E-8$ & .033 \\
\hline $2.3 E+6$ & 1.0 & $1.0 \mathrm{E}-4$ & .27 \\
\hline 6540 & 80 & $5 E-6$ & 452.5 \\
\hline $2.3 E+7$ & 2.9 & $3 E-5$ & .22 \\
\hline $1.4 E \cdot 10$ & во. & $2 E-6$ & 1. $1 \mathrm{E} \cdot 10$ \\
\hline 8. $5 E+3$ & 1120. & $4 E-6$ & .18 \\
\hline 15 & 80. & $2 E-4$ & $6.9 E+4$ \\
\hline 433 & 1130. & $4 E-6$ & 1600 \\
\hline $2.14 E 6$ & 23 & $3 E \cdot 6$ & 32 \\
\hline 1.5BE5 & 2.9 & $3 E-5$ & $3.8 E-5$ \\
\hline 7340 & 80. & 7E- 6 & 2.8E-O \\
\hline 4760 & 1120. & $4 E-6$ & $3.5 E-2$ \\
\hline $3.8>E 5$ & 80 & $5 E-6$ & 1.6 \\
\hline 4. $47 \mathrm{E} 9$ & 2.9 & $4 E-4$ & .32 \\
\hline $244 E 5$ & 2.9 & $3 E \cdot 5$ & 804 \\
\hline I.JE4 & go. & $2 E-6$ & 4. IE- 6 \\
\hline 1600 & .7 & $3 E \cdot 8$ & 7. $4 E-9$ \\
\hline $7.37 \mathrm{E} 3$ & 1130. & $4 E \cdot 6$ & 14.7 \\
\hline $2.439 E 4$ & 80 & $5 E-6$ & 290 \\
\hline $7.04 \mathrm{Ea}$ & 2.9 & $3 E-5$ & .016 \\
\hline $3.25 E 4$ & 100 & $9 E-7$ & $5.35 E-6$ \\
\hline
\end{tabular}


None of the transuranic nuclides was discharged to the Colorado River in a model run time of two million years. These radionuclides were contained in the ground water and sorbed on the geologic media at varying distances between the repository and the river.

\section{HAINESV ILLE TRANSPORT MODEL}

The contaminants were assumed to be released from the repository into the ground-water stream according to the leach rate model. Nuclides not interacting with the porous media were transported with the water, whereas nuclides that were adsorbed by the soil matrix moved with a retarded velocity.

As in the studies previously discussed, the hydrologic model was used to define multiple flow tubes (Figures 35 and 36 ) along the flow path. The MMT transport code was used to evaluate four cases:

1. Base Case, with the exit point in the regional depression around the East Texas $0 i 1$ Field (Figure 35), as reflected by the present hydrologic system. Breach occurs at 150 years and at 1050 years after the repository closure.

2. Base Case, with the East Texas $0 i 1$ Field removed from the hydrologic model (Figure 36). This gives exit points in the Sabine River and Big Cypress Bayou. Only the release at 150 years post-closure was analyzed.

3. Well Pumping Case, with the we 11 located $6 \mathrm{~km}$ from salt dome. Only the release at 150 years post-closure was analyzed.

4. Base Case with the East Texas $0 i 1$ Field removed, exit into the Sabine River on $7 y$, using lower bound $k_{d}$ values.

The nuclides considered in the four cases, their half-lives and average $K_{d}$ values are listed in Table 17 . The initial inventory is the total inventory from the Preliminary Information Report (PIR) assemblies list, provided by Bechtel National, Inc., (BNI) at 10 years of age of waste. The 200-year inventory is that of 200-year-old waste in the repository, with geotransport beginning at that time. Simulations were run to 2 million years, except that the well-pumping case ended at 150,000 years. A beta value of 6.0 and an effective porosity value of 0.2 were used in a 11 runs. 
TABLE 17. Simulation Inventories, $\mathrm{Ha}_{\mathrm{f}}$-Lives, and $\mathrm{K}_{d}$ Values for the Hainesville Study

\begin{tabular}{|c|c|c|c|c|c|}
\hline \multirow[b]{2}{*}{ Nuclide } & \multirow{2}{*}{$\begin{array}{l}\text { Half-Life, } \\
\text { years }\end{array}$} & \multirow{2}{*}{$\begin{array}{l}\text { Initial } \\
\text { Inventory, } \\
\text { curies } \\
\end{array}$} & \multirow{2}{*}{$\begin{array}{l}\text { Delayed (a) } \\
\text { Inventory, } \\
\text { curies } \\
\end{array}$} & \multicolumn{2}{|c|}{$\begin{array}{c}\mathrm{K}_{\mathrm{d}} \\
\mathrm{ml} / \mathrm{g} \\
\end{array}$} \\
\hline & & & & Brine & Water \\
\hline${ }^{3} \mathrm{H}$ & 12.35 & $3.45 \mathrm{E} 7$ & $4.59 E 2$ & 0 & 0 \\
\hline${ }^{14} \mathrm{C}$ & 5730 & $1.14 \mathrm{E} 5$ & $1.11 E 5$ & 0 & 0 \\
\hline${ }^{79} \mathrm{Se}$ & $6.5 E 4$ & $2.98 \mathrm{E} 4$ & $2.97 E 4$ & 24 & 24 \\
\hline${ }^{90} \mathrm{Sr}$ & 28.5 & $4.30 \mathrm{Eg}$ & $3.32 \mathrm{E} 7$ & 0 & 270 \\
\hline${ }^{99} \mathrm{Tc}$ & $2.13 E 5$ & $9.72 \mathrm{E} 5$ & $9.71 E 5$ & 1.5 & 0 \\
\hline${ }^{129} \mathrm{I}$ & $1.57 \mathrm{E} 7$ & $2.29 E 3$ & $2.29 E 3$ & 0 & 0 \\
\hline $135 \mathrm{Cs}$ & $2.3 \mathrm{E} 6$ & $2.84 E 4$ & $2.64 E 4$ & 0 & 11 \\
\hline & & Decay Cha & & & \\
\hline
\end{tabular}

Thorium Series:

$\begin{array}{lcllcc}240 \mathrm{Pu} & 6540 & 3.85 \mathrm{E} 7 & 3.77 E 7 & 250 & 73 \\ { }^{236} \mathrm{U} & 2.34 \mathrm{E} 7 & 1.84 \mathrm{E} 4 & 1.86 \mathrm{E} 4 & 1.5 & 1.5 \\ 232 \mathrm{Th} & 1.4 \mathrm{E} 10 & 0 & 1.83 \mathrm{E}-4 & 40 & 40\end{array}$

Neptunium Series:

$\begin{array}{lclllc}241_{\mathrm{Am}} & 433 & 3.26 \mathrm{E} 8 & 2.37 \mathrm{E} 8 & 0 & 75 \\ 237 \mathrm{~Np} & 2.14 \mathrm{E} 6 & 2.25 \mathrm{E} 4 & 4.05 \mathrm{E} 4 & 0 & 6.6 \\ 233_{\mathrm{U}} & 1.58 \mathrm{E} 5 & 0 & 2.80 \mathrm{E} 1 & 1.5 & 1.5 \\ 229 \mathrm{Th} & 7340 & 0 & 2.34 \mathrm{E}-1 & 40 & 40\end{array}$

Uranium Series:

$\begin{array}{lcllcc}{ }^{242} \mathrm{Pu} & 3.87 E 5 & 1.31 \mathrm{E5} & 1.30 E 5 & 250 & 73 \\ 238_{\mathrm{U}} & 4.47 E 9 & 2.45 \mathrm{E} 4 & 2.45 E 4 & 1.5 & 1.5 \\ { }^{230} \mathrm{Th} & 7.7 \mathrm{E} 4 & 9.01 & 8.43 E 1 & 40 & 40 \\ 226 \mathrm{Ra} & 1600 & 2.41 \mathrm{E}-2 & 3.94 & 15 & 15\end{array}$

Actinium Series:

\begin{tabular}{|c|c|c|c|c|c|}
\hline${ }^{243} \mathrm{Am}$ & 7370 & $1.16 \mathrm{E} 6$ & $1.14 \mathrm{E} 6$ & 0 & 76 \\
\hline${ }^{239} \mathrm{Pu}$ & $2.44 E 4$ & $2.36 E 7$ & $2.35 E 7$ & 250 & 73 \\
\hline${ }^{239} \mathrm{U}$ & $7.04 E 8$ & 0 & 4.63 & 1.5 & 1.5 \\
\hline${ }^{23} 1_{\mathrm{Pa}}$ & $3.25 E 4$ & 0 & $9.52 E-8$ & 40 & 40 \\
\hline
\end{tabular}

(a) Decayed inventory for 200-year-old waste 150 years postclosure. 
The elimination of the East Texas 0il Field resulted equally in a Sabine River discharge and a Big Cypress Bayou discharge. Release inventory, therefore, was divided equally between two flow tubes. In all cases, the flow tube dimensions were calculated to subtend the repository and include $260 \mathrm{gpm}$ $\left(1.8 \times 10^{7} \mathrm{ft}^{3} / \mathrm{yr}\right)$ of ground-water flow. The transport parameters are provided in Table 18.

The transport results for each case, reported as total curies discharged, are sumarized in Table 19.

TABLE 18. Hainesville Study Transport Parameters

\section{Case 1. East Texas 0il Field}

$\begin{array}{ll}\text { Path length } & 196,673 \mathrm{ft} \\ \text { Flow tube dimensions } & 29,400 \times 234 \mathrm{ft} \\ \text { Travel time } & 14,832 \mathrm{yr} \\ \text { Flow velocity } & 13.26 \mathrm{ft} / \mathrm{yr} \\ \text { Dispersion parameter } & 770 \mathrm{ft}\end{array}$

Case 2. Sabine River and Big Cypress Bayou

\begin{tabular}{llll} 
& \multicolumn{1}{c}{ Sabine } & & \multicolumn{1}{c}{ Cypress } \\
\cline { 2 - 2 } Path length & 326,462 & & $343,411 \mathrm{ft}$ \\
Flow tube dimensions & $20,932 \times 288$ & & $30,647 \times 167 \mathrm{ft}$ \\
Travel time & 43,015 & & $38,554 \mathrm{ft}$ \\
Flow velocity & 7.6 & & $8.9 \mathrm{ft} / \mathrm{yr}$ \\
Dispersion parameter & 164 & $504 \mathrm{ft}$ \\
Flow & $130 \mathrm{gpm}$ & $130 \mathrm{gFm}$
\end{tabular}

Case 3. Well Pumping Case

$\begin{array}{ll}\text { Path length } & 22,889 \mathrm{ft} \\ \text { Flow tube dimensions } & 10,032 \times 418 \mathrm{ft} \\ \text { Travel time } & 1,050 \mathrm{yr} \\ \text { Flow velocity } & 21.8 \mathrm{ft} / \mathrm{yr} \\ \text { Dispersion parameter } & 162 \mathrm{ft} \\ \text { Flow } & 260 \mathrm{gpm} \\ \text { Pumping rate } & 400 \mathrm{gpm}\end{array}$


TABLE 19. Cumulative Radiocontaminant Discharge in Curies for the Four Hainesville Study Release Scenarios After Geotransport Based on Solution Mining Beginning at Time 100 Years After Closure

\begin{tabular}{|c|c|c|c|c|c|}
\hline \multirow[b]{2}{*}{ Nucli de } & \multicolumn{5}{|c|}{$\frac{\text { Cumulat ive Uischarge, curies }}{\text { Simulation Number }}$} \\
\hline & $(1)$ & $\frac{S i}{(2 a)^{S}}$ & $\frac{\text { lation } \mathrm{Nu}}{(2 \mathrm{~b})}$ & $\frac{e r}{(3)}$ & (4) \\
\hline${ }^{14} \mathrm{C}$ & $5.21 E 3$ & $8.90 E 1$ & $1.52 \mathrm{E} 2$ & $2.50 E 4$ & $8.88 \mathrm{E} 1$ \\
\hline${ }^{79} \mathrm{Se}$ & 0 & 0 & 0 & 0 & 0 \\
\hline${ }^{99} \mathrm{TC}$ & $5.43 \mathrm{E} 5$ & $2.46 E 5$ & $3.88 E 5$ & $4.32 E 5$ & $2.46 E 5$ \\
\hline 129 I & $2.28 E 3$ & $1.14 \mathrm{E} 3$ & $1.14 E 3$ & $2.28 \mathrm{E} 3$ & $1.10 E 3$ \\
\hline${ }^{135} \mathrm{Cs}$ & $2.49 E 4$ & $7.74 E 3$ & $7.71 E 3$ & $1.66 E 4$ & $7.68 E 3$ \\
\hline${ }^{240} \mathrm{Pu}$ & 0 & 0 & 0 & 0 & 0 \\
\hline $236_{U}$ & 2.90E4 & $1.44 E 4$ & $1.44 E 4$ & $2.91 E 4$ & $1.44 E 4$ \\
\hline${ }^{232} \mathrm{Th}$ & $1.13 E-1$ & $4.73 E-2$ & 4. $84 E-2$ & $7.96 \mathrm{E}-3$ & $3.87 E-1$ \\
\hline${ }^{241}{ }_{A m}$ & 0 & 0 & 0 & $1.07 \mathrm{E} 6$ & 0 \\
\hline${ }^{237} \mathrm{~Np}$ & $8.05 E 4$ & $3.53 \mathrm{E} 4$ & $3.50 \mathrm{E} 4$ & $8.67 E 4$ & $4.0 \mathrm{E} 4$ \\
\hline $233_{U}$ & 7.31E4 & $4.90 E 4$ & $5.12 E 4$ & $1.52 \mathrm{E} 4$ & $2.84 E 4$ \\
\hline${ }^{229} \mathrm{Th}$ & $4.47 E 3$ & $2.08 \mathrm{E} 3$ & $1.95 E 3$ & $7.49 \mathrm{E} 2$ & $1.17 E 3$ \\
\hline${ }^{242} \mathrm{Pu}$ & 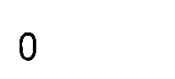 & 0 & 0 & 0 & 0 \\
\hline $238 U$ & $2.45 \mathrm{E} 4$ & $1.22 \mathrm{E} 4$ & $1.22 \mathrm{E} 4$ & $2.45 E 4$ & $1.22 E 4$ \\
\hline${ }^{234} U$ & $9.64 \mathrm{E} 4$ & 2.83E4 & $3.06 E 4$ & $1.31 \mathrm{E} 5$ & $3.39 E 4$ \\
\hline${ }^{230} \mathrm{Th}$ & $4.33 \mathrm{E} 3$ & $1.24 \mathrm{E} 3$ & $1.37 E 3$ & $3.59 \mathrm{E} 3$ & $1.07 E 3$ \\
\hline${ }^{226} \mathrm{Ra}$ & $9.48 \mathrm{E} 3$ & $2.55 \mathrm{E} 3$ & $3.19 E 3$ & $8.30 \mathrm{E} 3$ & $1.73 E 3$ \\
\hline${ }^{243} \mathrm{Am}$ & $8.75 \mathrm{E} 4$ & $3.08 \mathrm{E} 3$ & $4.55 E 3$ & $3.29 E 5$ & $3.08 E 3$ \\
\hline${ }^{239} \mathrm{Pu}$ & $2.26 \mathrm{E} 2$ & 8.36 & 6.81 & 3. 89E2 & 9.27 \\
\hline $235 \mathrm{U}$ & $8.16 \mathrm{E} 2$ & $4.12 \mathrm{E} 2$ & $6.00 E 5$ & $7.82 E 2$ & $5.50 E 5$ \\
\hline${ }^{231} \mathrm{~Pa}$ & $2.75 E 1$ & 7.48 & $1.26 \mathrm{E} 1$ & 2.96E1 & 5.93 \\
\hline
\end{tabular}

(1) Case 1. East Texas 0il Field discharge.

(2a) Case 2. Sabine River discharge.*

(2b) Case 2. Big Cypress Bayou discharge.*

(3) Case 3. Wel1 pumping case.

4) Case 4. Sabine River discharge.* Lower bound $K_{d}$.

* Represents half of released inventory.

NOTE: The format used here is analogous to scientific notation, e.g., $5.21 E 3=5.21 \times 10^{3}$. 
INFCE GRANITE TRANSPORT MODEL

The GETOUT CODE ${ }^{(35)}$ was used to simulate the movement of high-level wastes from the repository through the multiple flow tubes in the geosphere to the interface with the biosphere. The waste ccnsists of spent nuclear fuel in fuel cycles 1 and 4 and of vitrified waste in the other cycles. The transport calculations were performed for a repository containing waste from the production of $100 \mathrm{GWe} / \mathrm{yr}$. The nuclide inventories modeled are listed in Table 20.

The hydrologic model yielded an average ground-water travel time of 11,700 years. In the actual transport modeling this has been rounded off to 10,000 years. The repository's geometry gives a spread in the travel time for the five streamlines corresponding to a standard deviation of about 1300 years.

The average permeability and porosity for input to the GETOUT code have been evaluated as the time-integrated average over the projected flow path. The permeability obtained this way was $6 \times 10^{-9} \mathrm{~m} / \mathrm{sec}$, and the porosity $2 \times 10^{-4}$.

Chemical interactions between the dissolved waste nuclides in the ground water and the rock result in a retardation effect quantified by a retention factor specific for a given element in a certain chemical and geologic environment. The distribution coefficients, $\mathrm{K}_{d}\left(\mathrm{~m}^{3} / \mathrm{kg}\right)$, used for calculating the retardation factors, have been taken as the best estimate values used in References 31 and 32. The geochemical input data to the transport calculations are summarized in Table 21. The retention factors are higher than those used in References 31 and 32 by a factor of 1.8 due to the different porosity and permeability obtained in this study.

Table 22 sumarizes the GETOUT code results for high-level waste and spent fuel. All discharge rates to the biosphere calculated by the transport model are small. The earliest peak concentration observed is that for ${ }^{129}$ I at 11,000 years for release from spent fuel. No other fission product peaks of significance appeared. The peak concentrations for actinides all occur at 400 million years or later. 
TABLE 20. Radioactivity (Ci) in Spent Fuel Waste or Vitrification Reprocessing Waste for INFCE Granite Study Reference Fuel Cycles Per GWe yr (After 10 Years)

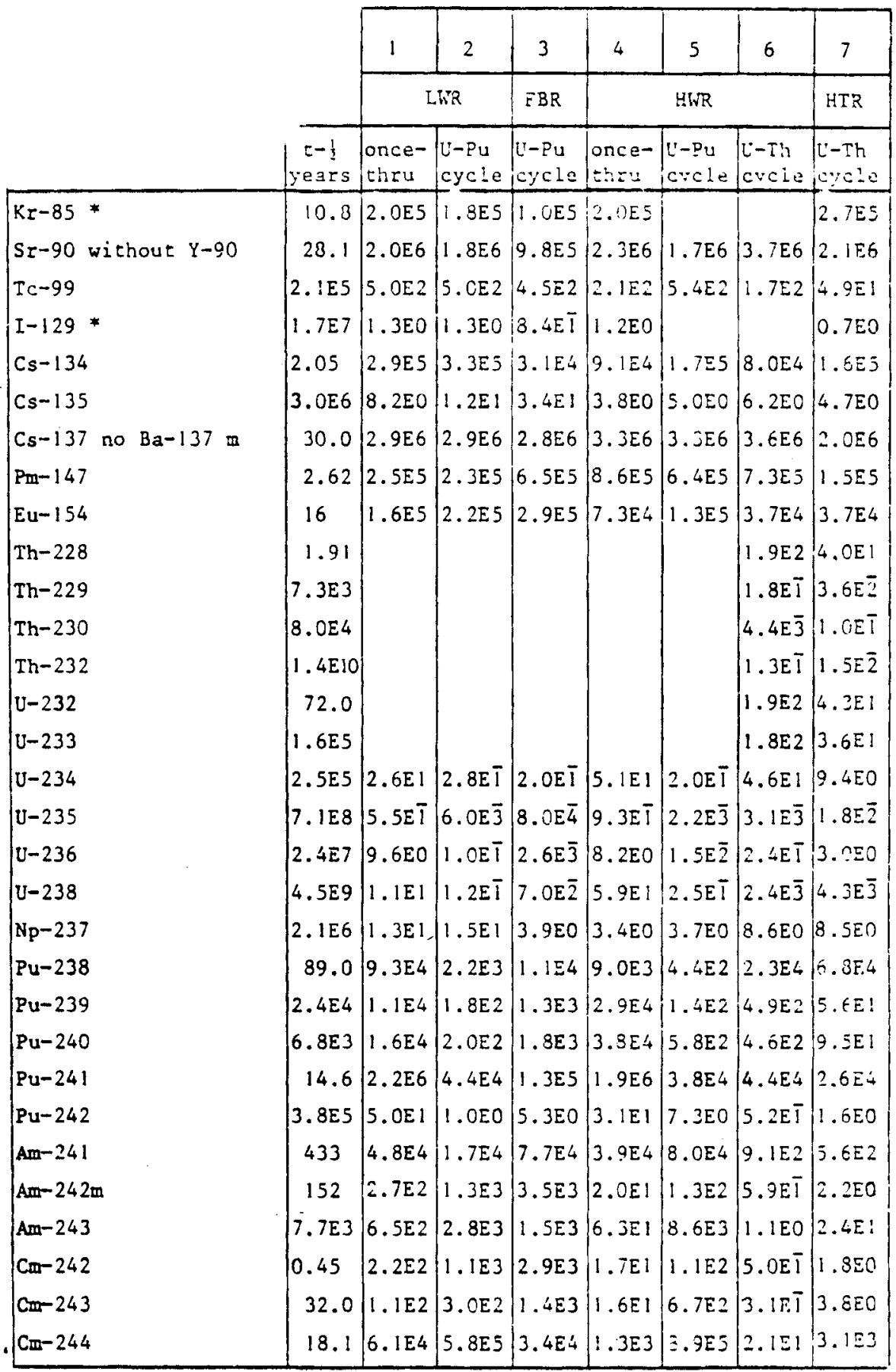

* Not in vitrified waste

NOTE: $2.2 \mathrm{E} 6$ means $2.2 \times 10^{6} ; 5.9 \mathrm{E} \overline{\mathrm{I}}$ means $5.9 \times 10^{-1}$ 
TABLE 21. Distribution Coefficients, $K_{d}$, and Retention Factors, $K_{j}$, Used in INFCE Granite Study Transport Calculations

\begin{tabular}{|c|c|c|}
\hline Element & $\mathrm{K}_{\mathrm{d}}, \mathrm{m}^{3} / \mathrm{kg}$ & $K_{i}$ \\
\hline Sr & 0.016 & 2,700 \\
\hline Tc & 0.05 & 1,700 \\
\hline I & 0 & 1 \\
\hline Cs & 0.064 & 7,000 \\
\hline $\mathrm{Ra}$ & 0.50 & 84,000 \\
\hline Th & 2.4 & 81,000 \\
\hline $\mathrm{Pa}$ & 0.6 & 20,000 \\
\hline$U$ & 1.2 & 41,000 \\
\hline$N p$ & 1.2 & 41,000 \\
\hline $\mathrm{Pu}$ & 0.30 & 10,000 \\
\hline Am & 32 & $1,080,000$ \\
\hline $\mathrm{Cm}$ & 16 & 540,000 \\
\hline
\end{tabular}

Because of the long transport times, the significant discharge rates to the biosphere arise from the long-lived nuclides ${ }^{235_{U}}$ and ${ }^{238} U$ and the ir daughter nuclides. As a consequence, the discharge rates from high-level waste are highest in those fuel cycles with the highest uranium concentration in the waste, i.e., cycles 1 and 4 .

The discharge rates to the biosphere from the non-high-level waste are virtually proportional to the total inventories of the predominant parent nuclides. This means that the discharge rates are largest in those fuel cycles with the largest amounts of uranium in the waste. Thus the discharge rates for the nuclide ${ }^{238} \mathrm{U}$ and its daughter nuclides are largest in cycles $1,2,5$ and 7 , while the discharge rates for ${ }^{235} U$ and its daughter nuclides are insignificant in all fuel cycles but cycles 1 and 2 . The enrichment tailings are generally the main source for most of the discharges from non-highlevel waste. In fuel cycle 5, however, the depleted uranium waste from reprocessing predominates. 


\section{TABLE 22. INFCE Granite Study Maximum Radionuclide Discharge}

Rates ( $\mathrm{Ci} / \mathrm{yr}$ ) and Times for the Maximum (Year) for High-Level Waste and Spent Fue 1

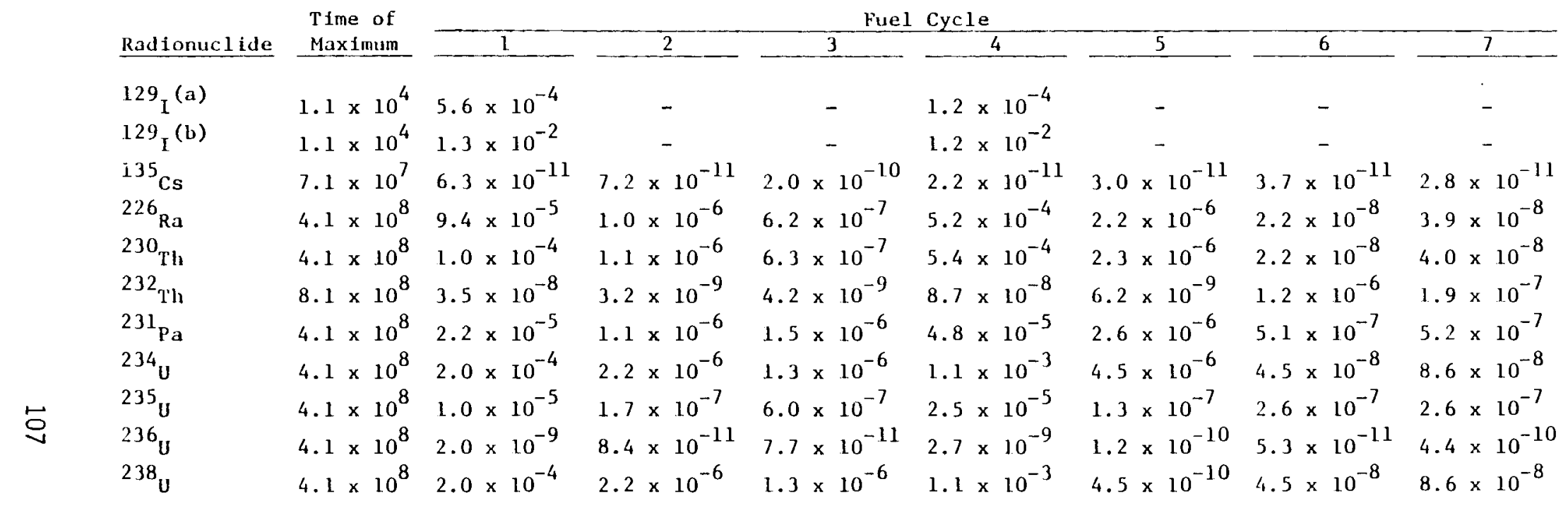

a. From $129 \Gamma$ - bound in fuel matrix.

b. From 129 l - in gap between fuel cladding and fucl matrix. 
Adding the discharges from high-level and non-high-level wastes, the oncethrough cycles give rise to the highest discharge rates. The differences due to the reprocessing cycle are, however, smaller than for the high-level waste discharges alone. 


\section{DOSE MODELING}

The release of radioactivity via ground water with subsequent transport to the biosphere can result in radiation dose to people. This section describes the biosphere transport and radiation dosimetry models used to estimate the potential radiation exposure for each of the studies discussed.

\section{INFCE SALT DOSE MODEL}

The dose codes used in the INFCE Salt Study are derivatives of ARRRG ${ }^{(36)}$ and FOOD. (37) These codes were originated at Pacific Northwest Laboratory for calculating annual radiation doses and long-term dose commitments to the total body and selected organs of individuals and to population groups, from both internal and external sources of radiation. The computer codes were developed to evaluate radiological impact in the Atomic Energy Commission's environmental statements for commercial power reactors and are applicable for any nuclear facility releasing radioactive materials to the environment. ARRRG calculates annual individual and population doses resulting from radionuclides released with liquid effluents. Various exposure pathways can be selected by the operator: consumption of fish, invertebrates, algae, and drinking water; and direct external radiation from shoreline, water immersion (swimming) and surface water (boating). Doses are calculated for skin (external only), total body, GI-LLI, thyroid and bone. Individual contributions to dose by nuclide and pathway are output.

ARRRG can calculate doses for eight organs and about 200 radionuclides. The user inputs the following variabies to ARRRG from data files: name of the facility under investigation; decay between release and point of exposure (holdup); usages; and mixing ratios by pathway; reactor coolant flow; shoreline width factor; and reconcentration factor parameters.

FOOD calculates annual individual doses from the consumption of agricultural foods and animal products contaminated from air deposition or water (sprinkler irrigated) for 14 food types. The input data for F00D includes facility name; holdups; usages; irrigation rates; air concentration; crop 
yields and growing periods for 14 food types (for animal products the parameters refer to animal's feed); and in the case of liquid release, the coolant flow and mixing ratio, and reconcentration factor parameters.

Because of time constraints of the study, it was not possible to use the complete versions of ARRRG and FOOD; however, shortened versions of ARRRG and FOOD reported in Burkholder et al. (38) were used to obtain doses for a generic river having an average flow rate of $500 \mathrm{~m}^{3} / \mathrm{sec}$.

There are several modes for assessing dose: maximum individual, average individual, local population, regional population, etc. The maximum individual (worst case) ${ }^{(a)}$ was used for this assessment. To obtain maximum possible doses, the times of peak isotope concentrations were obtained from the transport model, and the contribution to dose by all nuclides was calculated at each peak time.

The results presented in the study summarize, by nuclide, the doses (mrem) to five organs of the maximum individual (skin, body, GI-LLI, bone, and thyroid) for all seven reactor strategies. The doses are based upon 50 years buildup at the peak concentration followed by 50 years of exposure. The major contribution to dose is from ${ }^{226} \mathrm{Ra}$ and ${ }^{129} \mathrm{I}$. The highest dose, $290 \mathrm{mrem}$, resulted for Reactor Strategy 1 for ${ }^{226} \mathrm{Ra}$ in bone. The lowest bone dose for any reactor strategy was 0.5 mrem for Strategy 3.

These exposures should be compared with natural background: The average individual receives 5000 mrem from natural background radiation during the same 50-year period.

PARADOX BASIN STUDY

Dose modeling was not performed in the Paradox Basin Study.

(a) Maximum individual is a term meaning a person whose location and habits tend to maximize radiation dose. 


\section{HAINESVILLE DOSE MODEL}

The Hainesville Study assumed that it is misleading to provide dose calculations for one million years in the future based on the current social structure. This is because demographic patterns, feeding habits, and recycling pathways in ecosystems can change within a few centuries. This assumption resulted in limiting the dose calculations to only the operational aspects of the solution mining scenario at 100 and $1000 \mathrm{yr}$ after closure. No dose calculations were performed for radioisotopes subsequent to the abandonment of the breached solution mine. Only the transport calculations discussed in the previous section were performed.

The salt brine removed from the repository salt dome will contain radionuclides that may result in human exposure. For this analysis, the main route of exposure of the general population is taken to be use of the salt in the food industry; the ingestion of salt is the most direct and probably most consequential pathway. Other industrial use pathways that might result in dose to humans were not investigated.

A very simple, conservative near-field model was used to bound the dose consequences of an operational solution mine. For these analyses it was assumed that the waste form was spent fuel, and no credit was given to the potential protection that canisters, $c l$ adding and other engineered barriers might provide. In the conservative model used the solution mine was assumed to form preferentially at the repository level. The parameters and results for this operational phase of the solution mining scenario are:

- Operational life of solution mine $=50$ years without detection of radioactive wastes.

- Production per year $=1 \mathrm{milli}$ on tons year; $1.5 \times 10^{7} \mathrm{ft}^{3} / \mathrm{yr}$.

- Percent salt used for culinary uses $=3 \%$ of salt production.

- $1800 \mathrm{~g} \mathrm{salt/yr/person.}$

- All salt ingested is from contaminated source.

- Repository depth $=2100 \mathrm{ft}$ below 1 and surface. 
- Repository volume $(1375$ acres $\times 20 \mathrm{ft})=1.2 \times 10^{9} \mathrm{ft}^{3}$.

- Water injection flow rate $=1400 \mathrm{gpm}$.

- Solution withdrawal rate $=1200 \mathrm{gpm}$.

- Percent of inventory exposed per year $=1.2 \%$.

- Percent of inventory exposed after 50 years $=62 \%$.

- Congruent waste dissolutioning is controlled by uranium with a solubility limit of $6 \mathrm{ppm}$.

Based on these assumptions, the population served by $3 \%$ of the annual mine production is calculated to be $15 \mathrm{million}$ persons. Note that this population level is demographic-independent; i.e., the number of persons exposed depends on the amount of salt available rather than on particular population distributions.

The fraction of wastes in the repository removed during the 50 years of operation was calculated to be $0.97 \%$. This fraction is based on the solubility limit for uranium of $6 \mathrm{ppm}$ and a water flow rate of $1200 \mathrm{gpm}$ for the brining operations.

The fraction of the inventory consumed with table salt is then $3 \%$ of $9.7 \times 10^{-3}\left(2.94 \times 10^{-4}\right)$ since only $3 \%$ of the mined salt is used as table salt.

Using these estimates, 70-year radiation dose commitments were calculated for individuals and for the population consuming table salt over various time periods during the 50-yr mine operational period. The metabolic models and data presented in the International Commission on Radiological Protection Publication 2 (1959) $^{(39)}$ were used to estimate organ doses for intake via direct ingestion using the computer code PABLM. Doses to individuals and the population were calculated for the solution mining scenario with mining starting 100 years and 1000 years from present. Table 23 shows the doses calculated as a result of the simple conservative model of the operational phase of the solution mining scenario. 
TABLE 23. Radiation Doses Calculated for Hainesville Solution Mining Scenario (50-yr Ingestion)

$$
\text { 70-Year Population Dose, (a) man-rem }
$$

Time Solution

Mining Initiated,

yr

100

1,000

\begin{tabular}{|c|c|c|c|}
\hline Total Body & Bone & Lung & Thyroid \\
\hline $1.6 \times 10^{11}$ & $6.5 \times 10^{11}$ & $2.8 \times 10^{9}$ & $4.7 \times 10^{6}$ \\
\hline $1.3 \times 10^{9}$ & $3.0 \times 10^{10}$ & $3.7 \times 10^{4}$ & $4.7 \times 10^{6}$ \\
\hline
\end{tabular}

70-Year Individual Dose Commitments, rem

$\begin{array}{rllll}100 & 1.1 \times 10^{4} & 4.4 \times 10^{4} & 1.8 \times 10^{2} & 3.2 \times 10^{-1} \\ 1,000 & 8.4 \times 10^{1} & 2.0 \times 10^{3} & 2.5 \times 10^{-3} & 3.1 \times 10^{-1}\end{array}$

(a) Based on affected population of 15 million.

Further analyses on the Hainesville solution mining scenario are illustrated in Figure 42, where the 70-yr individual dose from a 50-yr ingestion is plotted versus various assumed times for initiation of the mining scenario. For the $100-y r$ scenario, ${ }^{90} \mathrm{Sr}$ and ${ }^{137} \mathrm{Cs}$ were the principal dose contributors; for the 1000-yr scenario, ${ }^{241} \mathrm{Am},{ }^{240} \mathrm{Pu},{ }^{239} \mathrm{Pu}$ and ${ }^{243} \mathrm{Am}$; for the $10,000-y r$ scenario, ${ }^{226} \mathrm{Ra},{ }^{240} \mathrm{Pu}, 239 \mathrm{Pu}$ and ${ }^{243} \mathrm{Am}$. For the later time periods $\left(30,000\right.$ to 1 million years), ${ }^{226} \mathrm{Ra}$ becomes the principal dose contributor. Total body doses are highest for the 100-yr scenario, then become smaller until the 10,000-yr scenario. After that they increase again as a result of the increase in the ${ }^{226} \mathrm{Ra}$ inventory, reach a peak at the $100,000-y \mathrm{r}$ scenario, and then decline again. For the 1 million-yr scenario, whole body doses are still three times higher than for the 10,000-yr scenario. For all cases analyzed, radiation doses exceeded background radiation, for some cases by several orders of magnitude.

The results of the human intrusion scenario used in the Hainesville study need to be reviewed carefully. These predicted doses are based on a set of extremely conservative assumptions with no credit given to operational barriers. In the conservative model used the entire 1200-gpm brine extraction 


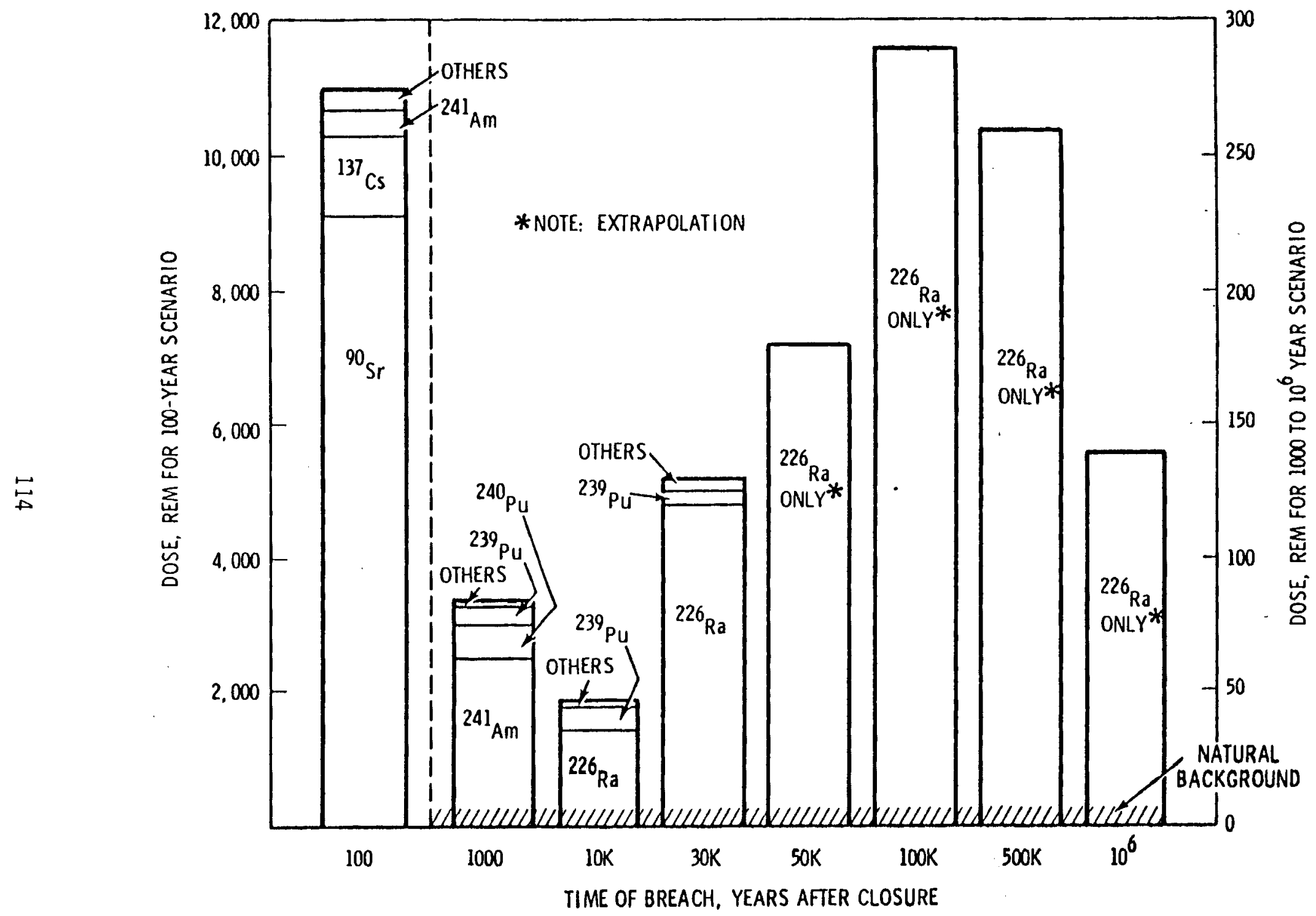

FIGURE 42. Solution Mining Scenario for Spent Fuel Repository 70-yr Individual Dose from 50-Yr Ingestion Doses in rem (Hainesville Study) 
quantity must flow past the waste in such a manner as to reach the $6 \mathrm{ppm}$ saturation limit. The brine cavity was assumed to grow only along the 20-ftthick layer of repository tunnels.

The Hainesville solution mining scenario and conservative dose estimates illustrate the importance of, and need for, engineered barriers. Functional barriers utilizing typical containment strategies could be effective for mitigating the consequences of the 100 and 1,000-yr (maybe longer) solution mining initiations. Barriers designed, however, to indirectly stop any future solution mining could provide protection for almost any time period. These kinds of barriers would make recovery of solution or mechanically mined salt uneconomic or unattractive. Backfill that would add color, taste, or smell or require some uneconomic purification procedure for the solution-mined salt could potentially be more effective than conventional containment-type barriers for human intrusion scenarios.

\section{INFCE GRANITE DOSE MODEL}

The biosphere environment selected for this generic study is representative of a typical granite site. This environment includes an inland lake with local farmlands and drainage to a larger intermediate (regional) lake or to the sea. The transport of radionuclides was modeled using the multicompartment mode 1 of Bergman, Bergstrom and Evans. (40) The biosphere model uses the deep ground-water activity release rate to determine the radioactivity in each compartment as a function of time. The compartment radioactivities are used in the pathway analysis to determine the rate of radionuclide intake for the maximum exposed individual. The radionuclide intake rates are used to calculate the dose received in the fiftieth year of exposure by the maximum exposed ind ividual.

The biosphere and dosimetry models were used to generate the maximum annual dose received by an individual for each of the seven fuel cycles evaluated. Table 24 presents the annual maximum individual dose (by radionuclide) for the high-level waste and spent fuel category. Table 25 shows the dose results for the non-high-level waste category. The dose represents the 
TABLE 24. Annual Maximum Individual Doses (rem/yr)

for High-Level Waste and Spent Fuel(a)

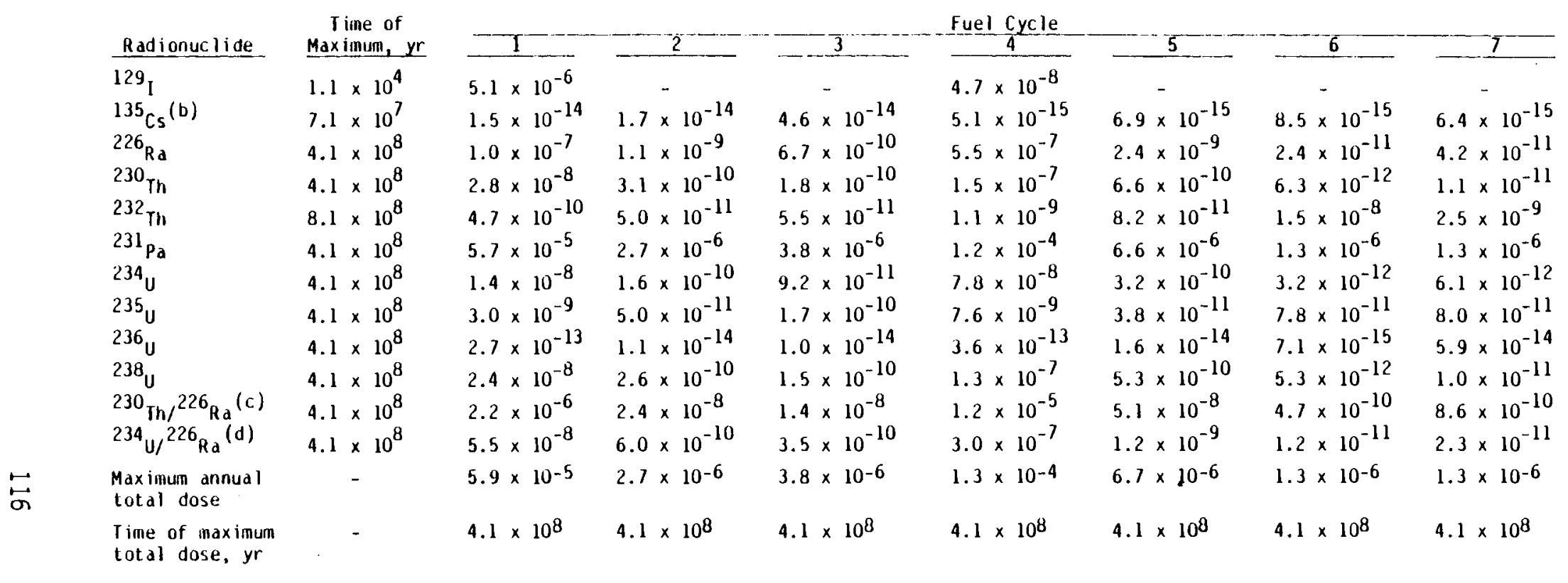

a) Fuel cycles ${ }^{2}$ and 4 represent disposal of spent fuel while the other cycles represent disposal of vitrified waste.

(b) Refers to $226 \mathrm{R}_{\mathrm{a}}$ that reaches the biosphere directly from the ground water.

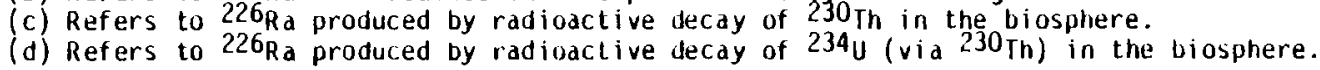


TABLE 25. Annual Maximum Individual Doses ( $\mathrm{rem} / \mathrm{yr}$ ) for Non-High-Level Waste Categories

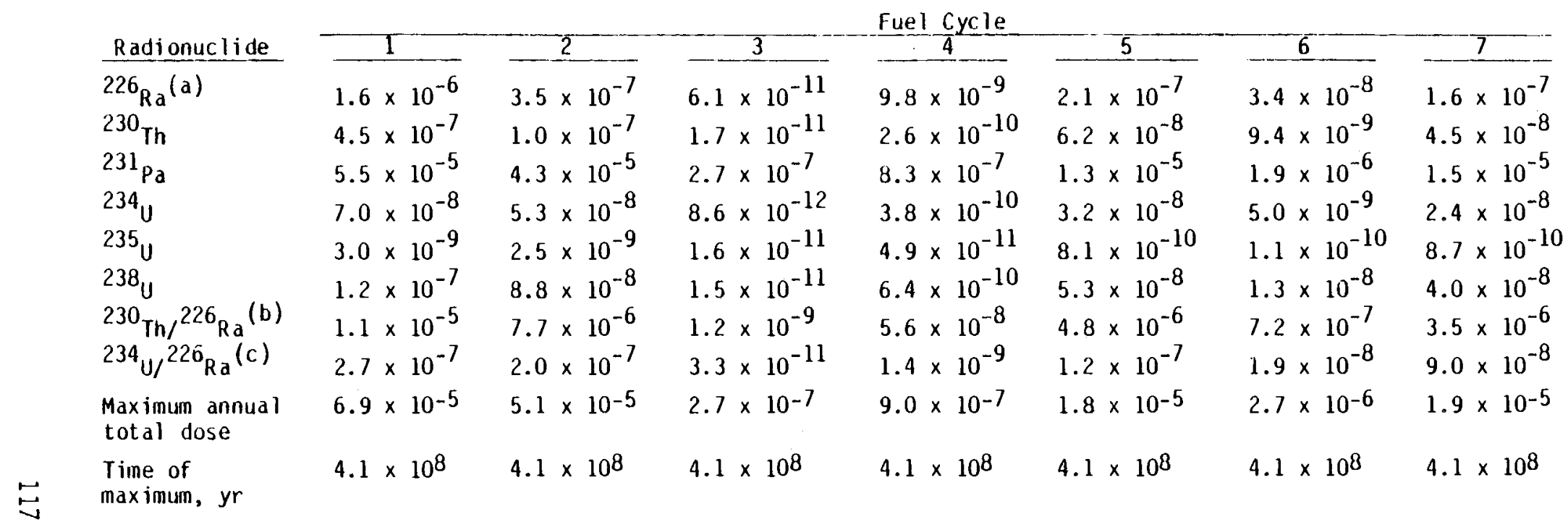

(a) Refers to $226 \mathrm{Ra}$ that reaches the biosphere directly from the ground water.

(b) Refers to $226 \mathrm{Ra}$ produced by radioactive decay of $230 \mathrm{Th}$ in the biosphere.

(c) Refers to $226 \mathrm{Ra}$ produced by radioactive decay of $234 \mathrm{U}$ (via $230 \mathrm{Th}$ ) in the biosphere. 
weighted whole-body dose received by the maximum exposed individual during the fiftieth year following $50 \mathrm{yr}$ of chronic intake.

The timing and magnitude of doses to the maximum individual parallel the radionuclide discharge rates to the biosphere. The highest doses appear at 400 million $y r$, with an earlier but smaller peak at 11,000 years from ${ }^{129}$ I for the once-through spent fuel cycles 1 and 4 . For the recycle fuel cycles the iodine is bound to silver zeolite filters and does not reach the environment. The highest calculated total dose of 0.13 mrem per year for high-level waste is we 11 below the average annual background dose rate of 100 mrem per year. The highest total dose for non-high-level waste was $0.069 \mathrm{mrem}$. The main contributors to dose were ${ }^{231} \mathrm{~Pa}$ and ${ }^{226} \mathrm{Ra}$ through the ingestion pathways.

Because the maximum individual doses are so small and are of similar magnitude, no differentiation can be made between the seven fuel cycles based on the possible doses to an individual in the very far future. 


\section{CONCLUSIONS}

The results of the four release consequence studies presented here demonstrate that numerical modeling can offer a practical approach to post-closure safety assessments of geologic formations as nuclear waste repositories. The far-field hydrologic, transport and dose methodology is the most developed and is generally applicable to various geologic media.

Improvement is needed, however, in the modeling of near-field effects and phenomena since the simple conservative models used in the above studies do not realistically assess the effects of engineered barriers, the waste form, the physical design of the repository, and other near-field hydrologic and geochemical effects. The simple mixed-tank model used in the Hainesville Study to assess the effects of the operational phase of the solution mining study illustrates the penalty associated with the use of very simple conservative models. A more realistic solution mining model that attempts to account, in a more realistic fashion, only for the geometry of growth of the solution mining cavity can reduce the potential dose estimates by a factor of nearly 60. It should be noted that this reduction would put all predicted dose estimates at or below background levels for all but the 100-yr human intrusion scenario. An even more realistic near-field model of this process that does not assume perfect mixing but does account for actual flow patterns within the cavity and past the exposed, failed waste canisters would reduce the predicted dose estimates even further. More realistic near-field models are needed not only to avoid having overly conservative estimates of consequences discredit an otherwise viable medium, but also to avoid the even more subtle trap of assuming that a simple model will always provide more conservative estimates of consequence.

The four release consequence studies summarized here generally indicate that the geohydrologic systems separating nuclear waste (stored in appropriate deep continental geologic formations) from the natural biosphere discharge sites mitigate the consequences of any of the postulated natural breaches in geologic containment. In all but one of these studies only natural biosphere 
discharge was considered since natural discharge of contaminated ground waters to surface water bodies can potentially affect a much greater population.

Further analyses of pumping well discharge scenarios should be made since they short-circuit a major portion of the geosphere. Consequences for pumping wel1 scenarios can potentially be greater, but the exposed population is smaller. For natural biosphere discharge sites, discounting the effects of engineered barriers and the near field, as was done in the four studies presented here, did not result in any significant consequences because of the mitigating power of the geosphere system along the path to a natural discharge. However, for the human intrusion or the pumping well scenario, such as was considered for the Hainesville Study, the effects of the physical design of the repository, the leach resistance of the waste form, the mitigating power of the engineered barrier systems, and other near-field physical and chemical phenomena should not be discounted since these kinds of intrusion scenarios bypass the mitigating power of the geosphere.

The Hainesville human intrusion scenario illustrates that engineered barriers could effectively reduce consequences by causing early cessation of, or actually preventing, inadvertent human intrusion. Backfill in the salt dome that would make the solution-mined salt either unattractive for culinary or industrial use or require such purification that the waste stream from this process would lead to early detection and cessation. It is not clear that engineered barriers of these kinds can be developed, but the solution mining scenario does illustrate that barriers of other than the typical containment or adsorption type may be useful. The importance of appropriate surface marking of repository boundaries to prevent inadvertent intrusion during the first $1000 \mathrm{yr}$ is also demonstrated. 


\section{ACKNOWLEDGMENTS}

This report, sponsored by the Department of Energy, summarizes four studies. Hence the authors gratefully acknowledge the contributions of many persons.

The Paradox Basin Study and the Hainesville Salt Study were sponsored by DOE and the Office of Nuclear Waste I solation (ONWI) as part of the Assessment of Effectiveness of Geologic Isolation Systems (AEGIS) Program. Directed by A. Brandstetter, formerly with PNL and now with ONWI, this large effort involved many contributors.

The other two studies (for salt and granite) are part of the work performed by Working Group 7 of the International Nuclear Fuel Cycle Evaluation. These studies were coordinated by J. V. Robinson of PNL and A. Larsson of the Swedish Nuclear Power Inspectorate. Swedish contributors included T. Papp of the Swedish Nuclear Fuel Supply Company, B. Grundfelt of the Konsult AB, U. Bergström of Studsvik, and L. Carlsson of the Geological Survey of Sweden. Canadian authors were J. Gale of the University of Water 100 and K. Dormuth of Atomic Energy of Canada, Ltd. PNL contributors in addition to the authors of this report were E. C. Watson, W. L. Kuhn, R. J. Serne, J. K. Soldat, and D. L. Strenge. 


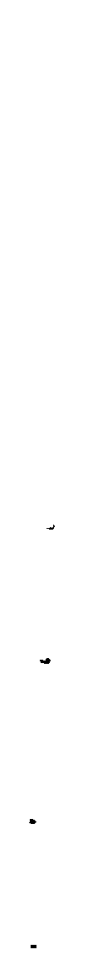




\section{REFERENCES}

1. Working Group 7 of the International Nuclear Fuel Cycle Evaluation. February 1980. Release Consequence Analysis for a Hypothetical Geologic Radioactive Waste Repository in Salt. INFCE/DEP/WG.7/16, International Atomic Energy Agency, Vienna, Austria.

2. Working Group 7 of the International Nuclear Fuel Cycle Evaluation. December 1979. Release Consequence Analysis for a Hypothetical Geologic Radioactive Waste Repository in Hard Rock. INFCE/DEP/WG.7/21, International Atomic Energy Agency, Vienna, Austria.

3. Test Case Release Consequence Analysis for a Spent Fuel Geologic Repository in Bedded Salt. January 1980. PNL-2782, Pacific Northwest Laboratory, Richland, Washington.

4. Harwe 11, M. A., et al. December 1979. Reference Site Initial Assessment for a Salt Dome Repository (Working Document). PNL-2955, Pacific Northwest Laboratory, Richland, Washington.

5. U.S. Department of Energy. 1979. Waste Isolation Pilot Plant EIS/ER. Chapter 2, Sections 2.4 through 2.5, Chapter 10, Sections 10.1 through 10.4. Washington, D.C.,

6. Cole, C. R. and F.W. Bond. January 1980. Comparison of Intera and WISAP Consequence Model Application. PNL-3070, Pacific Northwest Laboratory, Richland, Washington.

7. Hi11, M. D. and P. D. Grimwood. January 1978. Preliminary Assessment of the Radiological Protection Aspects of Disposal of High-Level Waste in Geologic Formations. National Radiation Protection Board, Harwe 11, U.K.

8. Handling and Final Storage of Unreprocessed Spent Nuclear Fuel. KBS, Stockholm, Sweden, 1978.

9. Handling of Spent Nuclear Fuel and Final Storage of Vitrified High-Level Reprocessing Waste. KBS, Stockholm, Sweden, 1978.

10. Management of Radioactive Waste from Finnish Nuclear Power Plants. June 1978. Imatran Power Co. and Teollisuuden Power Co.

11. Working Group 7 of the International Nuclear Fuel Cycle Evaluation. 1979. A Repository of Solidified Nuclear Waste in a Deep Tertiary Clay Formation in Belgium. INFCE/DEP/WG.7/19, International Atomic Energy Agency, Vienna, Austria.

12. Paces, T. 1973. "Steady-State Kinetics and Equilibrium Between Groundwaters and Granitic Rock." Geochim. et Cosmochim. Acta. 37:2641-2663. 
13. International Nuclear Fuel Cycle Evaluation. 1980. Waste Management and Disposal: Report of INFCE Working Group 7. International Atomic Energy Agency, Vienna.

14. International Nuclear Fuel Cycle Evaluation. July 1978. "Appendix to the INFCE Working Group 7 Report, Technical Details of a Geologic Repository in Salt for the Disposal of Radioactive Wastes." CC WG.7/38, prepared in support of the INFCE discussions at the direction of the Division of Waste Management, U.S. Department of Energy.

15. U.S. Department of Energy, December 1978. Draft Environmental Impact Statement: Management of Commercially Generated Radioactive Waste. DOE-1559, VoT. 1, Section 3, Table 3.1.1. Washington, D.C.

16. Wengard, S. A. and M. L. Matheny. 1958. "Pennsylvanian Systems of the Four Corners Region." Amer. Assoc. of Petr. Geol. Bulletin. $\underline{42}(9): 2048-2106$.

17. Hite, R. J. and J. A. Liming. 1972. "Stratigraphic Section Through the Pennsylvania System in the Paradox Basin." In Geologic Atlas of the Rocky Mountain Region, pp. 134-135.

18. Hintze, L. F. and W. L. Stokes. 1964. Geologic Map of Southwestern Utah. Utah State Land Board.

19. Hanshaw, B. and G. Hi11. 1969. "Geochemistry and Hydrodynamics of the Paradox Basin Region, Utah, Colorado and New Mexico." Chemical Geology. $\quad$ 4:263-294.

20. Working Group 7 of the International Nuclear Fuel Cycle Evaluation. May 1979. Technical Details of Geologic Repository in Hard Crystalline Rock for the Disposal of Radioactive Wastes, INFCE WG.7/41, Appendix $B$. International Atomic Energy Agency, Vienna, Austria.

21. Working Group 7 of the International Nuclear Fuel Cycle Evaluation. Apri1 1979. Granite Repository - Geochemical Environment. INFCE/DEP/WG.7/13. Internationa 1 Atomic Energy' Agency, Vienna, Austria.

22. Gale, J.E. 1975. A Numerical, Field and Laboratory Study of Flow in Rocks with Deformable Fractures. Thesis, University of California, Berkeley, California.

23. Iwai, K. 1976. Fundamental Studies of Fluid Flow Through a Single Fracture. Thesis, University of California, Berkeley, California.

24. Snow, D. T., 1968. "Rock Fracture Spacings, Openings, and Porosities." J. So i1 Mech. 94:73-91, Foundations Div., Proc. Amer. Soc. Civ. Engrs.

25. Davis, S. N. and L. J. Turk. 1964. "Optimum Depth of Well in Crystalline Rocks." Groundwater. 2:6-11. 
26. Brace, W. F. 1980. "Permeability of Crystalline and Argi11 aceous Rock." Int. J. Rock Mech. Min. Sci. \& Geomech. Abstr. 17:241-251. Pergamon Press.

27. Stokes, J. and R. Thunvik. 1978. Investigations of Ground-Water Flow in Rock Around Repositories for Nuclear Waste. KBS Technical Report 47, Stockholm, Sweden.

28. Neretnieks, I. May 1979. Diffusion in the Rock Matrix--An Important Factor in Radionuclide Retardation? Lawrence Berkeley Laboratory, Berkeley, California.

29. Goldstein, P., G. O. Hultgren and R. W. Nelson. February 1978. A Model of Contaminant Diffusion from a Finite Live Source in a Dome Basalt Stratum to an Overlying Permeable Interbed. BCSR-39, Boeing Computer Sciences Richland, Inc., Richland, Washington.

30. Reisenauer, A. E. December 1979. Variable Thickness Transient GroundWater Flow Model, Vol. 1. Formulation. PNL-3160-1, U.S. Department of Energy.

31. Gupta, S. K., C. R. Cole and F. W. Bond. December 1979. Finite Element Three-Dimensional Ground-Water (FE3DGW) Flow Model - Formulation, Program Listings and User's Manua 1. PNL-2939, U.S. Department of Energy.

32. Neretnieks, I. February 20, 1978. Transports of 0xidants and Radionuclides Through a Clay Barrier. KBS Technical Report 79, Kungl Tekniska Högskolan, Stockholm, Sweden.

33. Alhstrom, S. W., H. P. Foote et al. 1977. Multicomponent Mass Transport-D iscrete Parcel Random Walk Mode Theory and Numerical Implementation. BNWL-2127, Pacific Northwest Laboratory, Richland, Washington.

34. U.S. Energy Research and Development Administration. April 1975. "Standards for Radiation Protection." ERDA Manual, Chapter 0524, (Appendix) Annex A, Table II, Column 2.

35. DeMier, W. V. et al. August 1979. GETOUT--A Computer Program for Predicting Radionuclide Decay Chain Transport Through Geologic Media. PNL-2970, Pac ific Northwest Laboratory, Richland, Washington.

36. Soldat, J.K., N. M. Robinson and D. A. Baker. 1974. Models and Computer Codes for Evaluating Environmental Radiation Doses. BNWL-1754, Pac if ic Northwest Laboratory, Richland, Washington. 
37. Baker, D. A., G. R. Hoenes and J. K. Soldat. Apri1 1976. "FO0D--An Interactive Code to Calculate Internal Radiation Doses from Contaminated Food Products." Conference on Environmental Modeling and Simulation (Proc. of Environmental Protection Agency Symposium), Cincinnati, Ohio.

38. Burkholder, H. C., M. O. Cloninger, D. A. Baker and G. Jansen. 1975. Incentives for Partitioning High-Level Waste. BNWL-1927, Pacific Northwest Laboratory, Richland, Washington.

39. International Commission on Radiological Protection. 1959. Report of Committee II on Permissible Dose for Internal Radiation. Publication 2, Pergamon Press, New York.

40. Bergman, R., U. Bergström, and S. Evans. 1978. Dose and Dose Commitment from Groundwater-borne Radioactive Elements in the Final Storage of Spent Nuclear Fue 1. AB Atomenergi, KBS Technical Report 100, Nyköping, Sweden. 
No. of

Copies

\section{OFFISITE}

UNITED STATES

A. A. Churm

DOE Chicago Patent Group

9800 South Cass Avenue

Argonne, IL 60439

27 DOE Technical information Center

R. E. Cunn ingham

Office of Nuclear Safety Materials and Safeguards

Room 562

Nuclear Regulatory Commission

7916 Eastern Avenue

Silver Springs, MD 20910

J. B. Martin

Oivision of Waste Management

Nuclear Regulatory Comission

Washington, DC 20555

W. E. Mott

DOE Division of Environmental Control Technology

Washington, DC 20545

10 DOE Office of NuClear Waste Management NEW, B-107, HQ

Washington, OC 20545

Attn: C. R. Cooley

C. H. George

C. A. Heath

E. F. Mastal

S. Meyers/R. Romatowsk $i$

$G$. Derte 1

A. F. Perge

V. G. Trice

D. L. Vieth

E. Wahlquist

William Barnard

Office of Technology Assessment

U.S. Congress

Washington, DC 20510

S. A. Mann

DOE Chicago Operations and Region Office

Argonne, IL 60439

3. Neff

Department of Energy

Columbus Program Office

$505 \mathrm{King}$ Avenue

Columbus, $\mathrm{OH} 43201$
No. of

Copies

J. B. Whitsett

DOE Idaho Operations office

550 2nd St.

Idaho Falls, ID 83401

2 DOE Oak Ridge Operations office

P.O. Box E

Oak Ridge, TN 37830

Attn: S.W. Ahrends

E. L. Keller

3 Oak Ridge National Laboratory

P.0. $80 \times x$

Oak Ridge, TN 37830

Attn: J. 0. Blomeke

A. L. Lotts

K. J. Notz

Los Alamos Scientific Laboratory

P.0. Box 1663

Los Alamos, NM 87544

4 DOE Savannah River Operations Office P.O. Box A

Aiken, SC 29801

Attn: E. S. Soldberg

T. B. Hindman

M. C. Kirkland

R. P. Whitfield

G. L. Ritter

Exxon Nuclear Idaho

P.0. Box 2800

Idaho Falls, ID 83401

C. A. Aquilana

EG\&G Idaho

P.O. Box 1625

Idaho Falls, ID 83415

S. G. Harbison

OOE San Francisco Operations

1333 Broadway

Oakland, CA 94612

5 DOE Albuquerque Operations Office

P.0. Box 5400

Albuquerque, NM 87185

Attn: J. L. Bellows

R. Campbell

R. Y. Lowrey

M. L. Matthews

D. T. Schuller

J. A. Buckham

Allied-General Nuclear Services

P.0. Box 847

Barnwe 11, SC 29812 
No. of

Copies

M. J. Steindler Argonne National Laboratory 9700 South Cass Avenue Argonne, IL 60439

7 Battelle Memorial Institute Office of Nuclear Waste I solation $505 \mathrm{King}$ Avenue Columbus, $\mathrm{OH} 43201$

Attn: A. Brandstetter

W. Carbiener

N. E. Carter

P. L. Hofmann

M. Kehnemuyi

R. W. Peterson

B. Rawles

2 Rockwell International

Rocky $\mathrm{Flats} P l$ ant

P.0. Box 464

Golden, Co 80401

Attn: 'N. S. Bennett

L. J. Smith

C. M. Brown

Rockive 11

Rocky Flats Area Office

P.0. Box 928

Golden, co 80401

7 E.I. Du Pont de Nemours Co.

Savannah River Laboratory

Aiken, SC 29801

Attn: W. H. Baker

W. R. Cornman

J. L. Crandall

J. A. Kelley

F. King

J. D. Spencer

P. H. Permar

R. Williams

Electric Power Research Institute

3412 Hiliview Avenue

P.O. Box 10412

Palo Alto, CA 94304

Environmental Protection Agency

Technological Assessment Division (AW-559)

Office of Radiation Programs

U.S. Environmental Protection Agency

Washington, DC 20460

4 Sandia Laboratories

Albuquerque, NM 87185

Attn: G. C. Allen, ur.

R. Jefferson

E. Minor

W. Weart
No. of

Copies

J. W. Bartlett

The Analytical Sciences Corp.

6 Jacob Way

Reading, MA 01867

R. E. Burns

2412 Cedar Park Drive

Port Angeles, WA 98362

R. G. Post

College of Engineering

University of Arizona

Tucson, AZ 85721

R. L. Murray

Department of Nuclear Engineering

North Carolina State University

Raleigh, NC 27650

M. T. Johnson

Advanced Energy Systems Division

Power Systems Co.

Westinghouse Electric Corp.

Box 10864

Pittsburgh, PA 25236

A. J. O'Donne 11

Bechtel Nationa 1, Inc.

P.0. Box 3965

San Francisco, CA 94119

F. K. Pittman

3508 Sagecrest Terrace

Ft. Worth, TX 76109

J. D. Osnes

RE/SPEC

P.0. Box 725

One Concourse Drive

Rapid City, So 57709

\section{FOREIGN}

J. Gale

Department of Earth Sciences

University of Water 100

water loo, Ontario

Canada N2L $3 G 1$

K. Dormuth

Atomic Energy of Canada, Ltd.

Pinawa, Manitoba

Canada ROE ILO

B. Grundfeldt KEMATKA Konsult $A B$

Linnegatan 52

S-11454 Stockholm, Sweden 
No. of

Copies

A. Larsson

Swedish Nuclear Power Inspectorate

Sehlstedtsgatan 11

Box 27106 , S-102 52

Stockholm, Sweden

T. Papp

SKBF/KBS

Box 5864

S- 10248

Stockholm, Sweden

L. Carlsson

Geological Survey of Sweden

Bredgrand 4

$5-75320$ Uppsala

$018 / 15 \quad 56 \quad 40$

Sweden

U. Bergstrom

Studsvik Energiteknik $A B$

Department of Radiation Protection and Waste Management

S-611 82 Nyköping

Sweden

\section{ONS ITE}

5 LOE Richland Operations Office

P. A. Craig

R. B. Goranson

H. E. Ransom

U. J. Schreiber

M. W. Shupe

6 Rockwe 11 Hanford Operations
H. Babad
R. A. Deju
C. G. Evans
R. J. Gimera
J. H. Roecker
D. D. Wodrich

No. of

Copies

3 UNC United Nuclear Industries

C. G. Jones

R. L. Miller

J. F. Nemec

West inghouse Hanford Company

A. G. Blasewitz

56 Pacific Northwest Laboratory

F. W. Bond (7)

5. M. Brown

D. B. Cear lock

T. D. Chikalla

C. R. Cole (7)

M. O. Cloninger

F. H. Dove

H. Drucker

C. E. Elderkin

R. M. Fleischman

A. J. Haverfield/W. R. Wiley

O. F. Hill

J. H. Jarrett

M. R. Kreiter

W. L. Kuhn

L. T. Lakey

R. C. Lijkala

R. P. Marshall

J. L. MCElroy/R. E. Nightingale

R. W. Mckee

R. D. Nelson

J. M. Nielsen/R. W. Perkins

D. E. Olesen

C. R. Palmer

A. M. Platt

J. A. Powell

J. V. Robinson (7)

J. M. Rusin

R. J. Serne

J. K. Soldat

D. L. Strenge

A. M. Sutey

C. M. Unruh

E. C. Watson

Technical Information (3)

Publishing Coordination CO (1) 
